\title{
Company Registration: Toward a Status-Based Antifraud Regime
}

\author{
Stephen J. Choi $\dagger$
}

A little over thirty years ago, in one of the most influential commentaries on U.S. securities law, Milton Cohen posited a simple but momentous observation: had the Securities Act of 1933 ("Securities Act") 1 and the Securities Exchange Act of 1934 ("Exchange Act") ${ }^{2}$ been enacted in the reverse order, our system of securities registration and disclosure would be entirely different. ${ }^{3}$ Enacted first, the Securities Act primarily concerns itself with one corporate event: the issuance of securities. As a result, the Securities Act is transaction-focused, requiring issuing companies to make a number of company and transaction-specific disclosures and to deliver this information to potential investors through a rigorous and sometimes uncertain process. ${ }^{4}$ The periodic disclosure provisions of the Exchange Act, on the other hand, are triggered not by a particular transaction but by a company's status. For instance, companies listed on a national securities exchange, ${ }^{5}$ or with a sufficiently large public following and asset

$\dagger$ Assistant Professor of Law, The University of Chicago. Special thanks to Un Kyung Park. I would also like to thank Douglas Baird, James Cox, Richard Epstein, Michael Klausner, Donald Langevoort, Paul Mahoney, Tracey Meares, and Lynn Stout for their helpful comments and suggestions. Financial support from the Russell Baker Scholars Fund, the Arnold and Frieda Shure Research Fund, and the John M. Olin Foundation is gratefully acknowledged.

${ }^{1}$ Securities Act of 1933 , Pub L No 73-38, 48 Stat 74, as amended by the Private Securities Litigation Reform Act, Pub L No 104-67, 109 Stat 737 (1995), codified at 15 USCA $\S 77$ (1981 \& Supp 1996).

2 Securities Exchange Act of 1934, Pub L No 73-404, 48 Stat 881, as amended by the Private Securities Litigation Reform Act, Pub L No 104-67, 109 Stat 737 (1995), codified at 15 USCA \& 78 (1981 \& Supp 1996).

${ }^{3}$ Milton H. Cohen, "Truth in Securities" Revisited, 79 Harv L Rev 1340, 1341-42 (1966) ("[]t is my plea that there now be created a new coordinated disclosure system having as its basis the continuous disclosure system of the [Exchange] Act and treating [Securities] Act' disclosure needs on this foundation."). See also Milton H. Cohen, The Integrated Disclosure System-Unfinished Business, 40 Bus Law 987, 987-88 (1985) (arguing that Exchange Act should be considered more "basic" than Securities Act because of Exchange Act's wider and continuous scope).

- Section 5 of the Securities Act, codified at 15 USC $\S 77 e$, governs this process. See also text accompanying notes $125-30$ (describing the registration process).

${ }^{5}$ See Section 13(a), Exchange Act, codified at 15 USC $\S 78 \mathrm{~m}$ (a) (specifying filing requirements); Section 12(b), Exchange Act, codified at 15 USC $\$ 781(\mathrm{~b})$ (detailing information required for registration application). See also Section 3(a)(1), Exchange Act, codified at 15 USC $\S 78 c(a)(1)$ (defining "exchange" for the purposes of the Exchange Act). 
base ${ }^{6}$ are obligated under the Exchange Act to make annual and quarterly public filings with the Securities and Exchange Commission ("SEC"). ${ }^{7}$ In assessing the two regimes, Cohen recognized that disclosures pursuant to a public offering under the Securities Act consist of information that all investors require prior to making an investment decision, including not only those investors purchasing from the offering, but also those trading in the secondary market. From this observation, Cohen called into question the need for mandatory disclosures directed toward parties of any particular transaction and argued for the reform of the securities regime toward one, unified company-based information disclosure scheme. ${ }^{8}$

Cohen's seminal article led the American Law Institute ("ALI") to draft a model federal securities code under the leadership of Professor Louis Loss in the 1970s. ${ }^{9}$ Embodying a company registration system, the model code received final ALI approval in $1980 .{ }^{10}$ Soon thereafter, however, the reform effort died;

- A company must register a class of equity securities (other than exempted securities) under the Exchange Act and accordingly satisfy the periodic reporting requirements of Section 13(a) if (1) the company's total assets exceed $\$ 10$ million and (2) more than five hundred shareholders hold, of record, the non-exempt class of securities. Section 13, Exchange Act, codified at 15 USCA § 78m; Section 12(g), Exchange Act, codified at 15 USCA § 781(g) (exemptions). See also Rule 12g-1, $17 \mathrm{CFR}$ § 240.12g-1 (1996), as amended by Relief from Reporting by Small Issuers, SEC Exchange Act Release No 37,157, [Current] Fed Sec L Rptr (CCH) II 85,801 (May 17, 1996) (raising the asset requirement to $\$ 10$ million).

"Commonly referred to as "Exchange Act Reporting Companies," the companies must file annual Form 10-K, quarterly Form 10-Q, and occasional Form 8-K with the SEC. See Section 13(a), Exchange Act, codified at 15 USC § 78m(a); Regulation 13A, 17 CFR $\S \S 240.13 a-1$ et seq (1996) (providing rules on periodic disclosure requirements of Exchange Act registered companies); Forms 10-K, 10-Q, 8-K, Exchange Act, 5 Fed Sec L Rptr (CCH) III 31,101-07 (July 10, 1996); II 31,031-35 (Apr 21, 1993); III 31,001-04 (Jan 25,1995 ) (forms for pexiodic reports under Section 13). Companies filing a registration statement that becomes effective under the Securities Act must also comply with the periodic reporting requirements. Section 15(d), Exchange Act, codified at 15 USC §78o(d).

${ }^{8}$ See Cohen, 79 Harv L Rev at 1341-42 (cited in note 3).

9 See ALI Federal Securities Code (1980). The SEC endorsed the ALI project twice, in 1980 and 1982. See Statement Concerning Codification of the Federal Securities Laws, SEC Securities Act Release No 6377, [1981-82 Transfer Binder] Fed Sec L Rptr (CCH) II 83,090 (Jan 21, 1982); Statement Concerning Codification of the Federal Securities Laws, SEC Securities Act Release No 6242, [1980 Transfer Binder] Fed Sec L Rptr (CCH) II 82,655 (Sept 18, 1980).

The SEC also looked into the possibility of moving toward a company registration system immediately after Cohen's article was published during the 1960s, an investigation that culminated in the Wheat Report. See generally Report of the Advisory Committee on Corporate Disclosure to the Securities and Exchange Commission, 95th Cong, 1st Sess (Nov 3, 1977), in 1 Committee Print 95-29 (GPO 1977); Disclosure to Investors: A Reappraisal of Administrative Policies under the '33 and '34 Acts (Mar 27, 1969) ('Wheat Report").

${ }^{10}$ See ALI Federal Securities Code at vii (cited in note 9). 
through inaction, Congress chose instead to retain the current dual transaction- and status-based framework. ${ }^{11}$ Recently, the SEC renewed its interest in Cohen's thirty-year-old proposal and initiated an investigation into the possibility of a more formal shift toward a company registration system. ${ }^{12}$ With Commissioner Steven Wallman as chair, the SEC's Advisory Committee on the Capital Formation and Regulatory Processes ("Advisory Committee") undertook this task. ${ }^{13}$ After over a year of research and consultation, the Advisory Committee released a report this past July outlining the fundamentals of a new company registration system, as well as a pilot program to test the feasibility of this system. ${ }^{14}$

In the face of renewed interest in company registration and the Advisory Committee's report, this Article argues that the company registration system that Milton Cohen envisioned is-in substance, if not in form-already largely in place within the present securities regulatory framework. In 1982, for example, the SEC promulgated several measures, introducing the integrated disclosure system and allowing certain Exchange Act reporting companies to "incorporate by reference" information from their Exchange Act filings into Securities Act registration documents. ${ }^{15}$ Then in 1983, the SEC sought to reduce the registration burden for Form S-3 issuers ${ }^{16}$ through the adoption of shelf regis-

"See John C. Coffee, Jr., Re-Engineering Corporate Disclosure: The Coming Debate Over Company-registration, 52 Wash \& Lee L Rev 1143, 1145-46 (1995) ("[W]hen the ALI's Federal Securities Code was presented to Congress in 1980, Congress essentially yawned and declined to act. Unfortunately, 'good government' reform does not excite powerful constituencies nor generate the level of emotion necessary to stir a lethargic Congress into action.").

${ }^{12}$ Certain members of Congress are also interested in removing some of the restrictions within the Securities Act. See Mark H. Anderson, Republicans in House Begin Push to Overhaul U.S. Securities Laws, Wall St J A2 (July 27, 1995) (noting that Representative Jack Fields introduced a bill that would "ease rules that require investors to get a prospectus before making an investment").

is The Advisory Committee's report was released on July 24, 1996. Chaired by Commissioner Steven M.H. Wallman, the other members of the committee included John C. Coffee, Jr., Barber B. Conable, Jr., Robert K Elliott, Edward F. Greene, George N. Hatsopolous, A. Bart Holaday, Paul Kolton, Roland M. Machold, Burton G. Malkiel, Claudine Malone, Charles Miller, Karen M. O'Brien, and Lawrence W. Sonsini. See Securities and Exchange Commission, Report of the Advisory Committee on the Capital Formation and Regulatory Processes, Fed Sec L Rep (CCH) No 1726 (Aug 5, 1996) (“Advisory Committee Report").

"See Advisory Committee Report at 13 (cited in note 13). The pilot program would be limited to those issuers with a $\$ 75$ million public float, two years of reporting history, and a class of securities listed on a national securities exchange or traded on the National Market System of the NASDAQ Stock Market. Id at 28.

${ }^{15}$ See text accompanying notes 248-56.

${ }^{16}$ A number of different registration forms are available to companies seeking to register securities for a public offering. For domestic companies, Forms S-1, S-2, and S-3 
tration under Rule $415,{ }^{17}$ providing S-3 issuers with the ability to pre-register securities reasonably expected to be issued within two years. ${ }^{18}$ These reforms recognized that for companies with securities in an efficient market, ${ }^{19}$ investors already possess much of the public information available to make an informed investment decision. ${ }^{20}$

A move toward a formal company-based registration system, as advocated by the Advisory Committee, therefore may not be necessary to achieve many of the substantive benefits of company registration. To the extent the current system falls short of the

constitute the major categories from which companies may select. All companies may use Form S-1, which requires complete registrant and transaction information disclosure. However, only companies with three years of Exchange Act reporting experience may use Form S-2 and thereby incorporate by reference registrant information contained in the companies' latest Form 10-K Form S-2 issuers must still, however, include a copy of the annual report or comparable information within the prospectus. Only companies with at least one year of Exchange Act reporting experience and meeting a minimum net capitalization requirement of $\$ 75$ million (by nonaffiliates) may make use of Form S-3 for certain non-investment grade offerings, thereby allowing the issuer to incorporate-byreference to a greater extent than under Form S-2. Form S-3 issuers must include only transaction-specific information on the offering. See Forms S-1, S-2, and S-3, Securities Act, 2 Fed L Sec Rptr (CCH) III 7121-26 (Jan 3, 1996) ("Form S-1"); III 7141-46 (Aug 23, 1995) ("Form S-2"); TII 7.151-55 ( $\operatorname{Jan} 3,1996)$ ("Form S-3") (explaining the requirements for using each of the forms and the information required on each form and on accompanying prospectuses).

${ }^{17} 17$ CFR § 230.415 (1996).

is See Shelf Registration, SEC Securities Act Release No 6499, [1983-84 Transfer Binder] Fed Sec L Rptr (CCH) If 83,449 (Nov 17, 1983). The SEC, moreover, in 1992 further loosened restrictions on shelf registration, adopting the "universal" shelf which allows Form S-3 issuers to register a specified dollar amount of securities for the shelf without allocating these securities to any particular class of securities. See Simplification of Registration Procedures for Primary Securities Offerings, SEC Securities Act Release No 6964, [1992 Transfer Binder] Fed Sec L Rptr II 85,053 (Oct 22, 1992).

29 This Article uses the term "efficient market" to refer to a trading market that displays features of a semistrong efficient market. See Eugene F. Fama, Efficient Capital Markets: A Review of Theory and Empirical Work, $25 \mathrm{~J}$ Fin 383 (1970) (providing a survey of theoretical implications of efficient markets and empirical testing of the efficient markets hypothesis). The semistrong version of the efficient capital markets hypothesis posits that the secondary market price of companies reflects all publicly available information on the company. See Donald C. Langevoort, Information Technology and the Structure of Securities Regulation, 98 Harv L Rev 747, 778-79 (1985). Not all economists, however, are universal in their support for the efficient markets hypothesis. See Donald C. Langevoort, Theories, Assumptions, and Securities Regulation: Market Efficiency Revisited, $140 \mathrm{U} \mathrm{Pa}$ L Rev 851, 866-72 (1992) (describing various theories against the efficient markets hypothesis).

${ }^{\infty}$ See generally Ronald J. Gilson and Reinier H. Kraakman, The Mechanisms of Market Efficiency, 70 Va L Rev 549 (1984). At least one scholar, Professor Donald C. Langevoort, argues that the efficient markets hypothesis had less influence on the integrated disclosure system or shelf registration than did political forces. See Langevoort, $140 \mathrm{U} \mathrm{Pa} \mathrm{L}$ Rev at 873-89 (cited in note 19) (arguing that the efficient markets hypothesis was not a strong motivating force behind the SEC's adoption of integrated disclosure and shelf registration). 
company registration ideal, reform within the current regulatory framework more easily achieves the few benefits of the Advisory Committee's proposed company registration system.

Furthermore, one alternative reform within the current system provides greater simplification benefits, as well as substantially all of the benefits of the formal company registration proposal, and rationalizes fraud deterrence in the primary offering context: status-based antifraud liability. ${ }^{21}$ As used in this Article, status-based antifraud liability refers to a deterrence system that imposes the same level of antifraud liability on an issuer regardless of the type of primary transaction in which the issuer engages; rather, the level of liability depends on the capitalization and market following of the particular issuer..$^{22} \mathrm{~A}$ statusbased antifraud liability system provides two major benefits. First, status-based antifraud takes advantage of market-based mechanisms that deter issuers from committing fraud. To the extent these market-based mechanisms are stronger for more well capitalized and followed companies, the value of additional antifraud liability is reduced; likewise, where these market-based mechanisms are weaker, a greater need is present for legal antifraud deterrence. More analysts, for example, follow well capitalized companies, providing these companies less room to misrepresent their value; furthermore, higher-quality securities professional intermediaries acting as gatekeepers will tend to focus on larger companies better able to defray the costs of screening for fraud. Second, through status-based antifraud, the artificial incentive for companies to employ a transaction exemption from the public offering process is reduced. Currently, companies through a private placement may reduce their antifraud liability exposure as compared to the public offering process. ${ }^{23}$ This in

${ }^{21}$ Writing separately, three Advisory Committee members-John C. Coffee, Jr., Edward F. Greene, and Lawrence W. Sonsini-call for a "corresponding transition in liability rules" to accompany a shift toward company registration. Advisory Committee Report at 36 (cited in note 13). They, however, focus almost entirely on clarifying the due diligence requirements of underwriters, outside directors, accountants, and other gatekeepers. Id at 36-41. Coffee has also written independently on moving toward a company registration system. See Coffee, 52 Wash \& Lee L Rev at 1155-72 (cited in note 11) (discussing the merits of a company registration system).

${ }^{22}$ In this Article, the level of antifraud liability for information disclosures not involving a primary transaction by the issuer is not directly covered. However, as discussed in note 107, an argument exists that even in secondary market disclosures companies should face a status-based system of antifraud liability.

${ }^{23}$ Companies going through a public offering potentially face antifraud liability under Sections 11 and 12(a)(2) of the Securities Act as well as under Rule 10b-5. Private placements, on the other hand, only must endure Rule 10b-5 antifraud liability. See Section 11(a), Securities Act, codified at 15 USC \$ 77k(a); Section 12(a)(2), Securities Act, codified at 15 USCA § 771(a)(2); Rule 10b-5, 17 CFR § 240.10b-5 (1996). 
turn leads to a greater volume of exempt transactions and restricted securities subject to the Securities Act's complex resale limitation provisions. With status-based antifraud liability, the magnitude of such restricted securities will diminish, resulting in more fully registered and transferable securities and therefore the same substantive benefits as with company registration. Status-based antifraud also mitigates enforcement costs, focusing resources on companies with the greatest risk of fraud and the fewest market-based mechanisms to control that risk. Moving toward a status-based antifraud regime, moreover, would leave most of the current system's existing framework in place, avoiding the confusion inherent in shifting to a completely new regulatory paradigm. ${ }^{24}$

In the present regulatory scheme, both the information disclosure and the level of antifraud liability are transaction-based. Section 11(a) of the Securities Act, for example, provides antifraud liability solely for material misstatements or omissions in the registration statement of a public offering. ${ }^{25}$ Antifraud liability under Section 12(a)(2) of the Securities Act, in turn, applies only to prospectuses in the public offering context. ${ }^{26}$ Finally, Rule 10b-5 liability applies generally to all securities-related disclosures, including those in private placements and Exchange Act filings. ${ }^{27}$ The implementation of a status-based antifraud system is straightforward: the level of antifraud liability for primary issuer transactions should turn on the status of the issuer and not

\footnotetext{
24 See text accompanying notes 43-70.

${ }^{25}$ See Section 11(a), Securities Act, codified at 15 USC $\$ 77 \mathrm{k}(\mathrm{a})$.

${ }^{25}$ See Section 12(a)(2), Securities Act, codified at 15 USCA \& 771(a)(2) (1996). See also Gustafson $v$ Alloyd Co, 115 S Ct 1061, 1071-74 (1995) (limiting the reach of Section 12(a)(2) to "public offerings [of securities] by an issuer (or a controlling shareholder)" involving a prospectus "that describes a public offering of securities by an issuer or controlling shareholder"). Section 17(a) of the Securities Act, codified at 15 USC \& 77q(a), also provides an additional antifraud provision for the sale of securities. Several circuit courts, however, have held that private plaintiffs lack any private right of action under this provision. See In re Washington Public Power Supply Systems Securities Litigation, 823 F2d 1349, 1354-57 (9th Cir 1987) (en banc); Brannan v Eisenstein, 804 F2d 1041, 1043 n 1 (8th Cir 1986); Landry $v$ All American Assurance Co, 688 F2d 381, 391 (5th Cir 1982). But see Kirshner $v$ United States, 603 F2d 234, 241 (2d Cir 1978) (indicating that a private right of action exists under Section 17(a)).

${ }^{2}$ Rule 10b-5, 17 CFR $\S 240.10 b-5$ (1996); Section 10(b), Exchange Act, codified at 15 USC \& 78j. See generally Harold S. Bloomenthal and Holme, Roberts \& Owen, Securities Law Handbook $\$ \$ 15.01-15.21$ (Clark Boardman 1997) (summarizing the elements of a Rule 10b-5 action).

Section 18 of the Exchange Act, codified at 15 USC $\S 78$ r(a), provides an additional antifraud liability provision for Exchange Act filings. Plaintiffs under Section 18, however, must prove actual reliance. As a result, scholars have deemed Section 18 a "dead letter," providing no real risk of liability for issuers. See, for example, Cohen, 40 Bus Law at 989 (cited in note 3).
} 
on the type of transaction. ${ }^{28}$ Drawing from the current statusbased distinction made in the Securities Act registration forms, this Article contends that where the issuer is a Form S-1 company, possessing little market experience and few market-based deterrents against fraud, it should be subject to the most stringent level of antifraud liability regardless of the type of transaction it undertakes. Conversely, Form S-2 and S-3 issuers, who are presumptively better followed and more highly capitalized, should face lower levels of antifraud liability.

The Article proceeds in the following fashion. Part I presents the arguments for a status-based antifraud regime and identifies several alternative market-based antifraud mechanisms. Part II provides a detailed analysis of recent efforts to shift more formally toward a status-based company registration and disclosure system. The Article argues that the Advisory Committee's recommendations, although appealing on a theoretical level, are largely peripheral to creating a company registration system. The Article supports this proposition by demonstrating that reforms instituted during the 1980s already introduced most of the substantive benefits of a company registration system within the Securities Act. Furthermore, those Advisory Committee recommendations that more directly introduce a pure company registration system both are unsuitable for non-S-3 companies and provide only incremental substantive changes to the current regime. Part III analyzes the relationship between status-based antifraud and company registration reform, arguing that statusbased antifraud liability achieves at a lower cost many of the incremental benefits that company registration provides for the current system.

\section{STATUS-BASED ANTIFRAUD LIABILITY}

Most of the recent debate regarding antifraud liability reform has centered around reforming procedural aspects of class action litigation to limit the threat of nuisance suits. ${ }^{29}$ The result

${ }^{23}$ Several other scholars and observers have recently argued for company registration. No one, however, has called for a status-based antifraud liability regime. See Roberta S. Karmel, Is Section 5 an Anachronism?, NY L J 3, 3 (Dec 21, 1995); John C. Coffee, Jr., Is the Securities Act of 1933 obsolete? The SEC increasingly appears to believe so but has not yet adopted a consistent policy to replace it., Natl L J B4 (Sept 4, 1995); Gerald S. Backman and Stephen E. Kim, A Cure for Securities Act Metaphysics: Integrated Registration, Insights 18 (May 1995) (proposing an abbreviated registration method for select companies that requires no prospectus or waiting period); Joseph McLaughlin, 1933 Act's Registration Provisions: Is Time Ripe for Repealing Them?, Natl L J 44 (Aug 18, 1986).

${ }^{2}$ A variety of theories exist to explain the ability of plaintiffs attorneys to bring suit and successfully obtain settlements for claims that otherwise would not prevail at trial. 
of years of effort from reform advocates, the Private Securities Litigation Reform Act of 1995 ("Litigation Reform Act") 30 increased the courts' role in monitoring for frivolous litigation and provided institutional investors with a greater ability to take control of plaintiffs' class actions. ${ }^{31}$ The Litigation Reform Act also strengthened forward-looking informational safe harbors ${ }^{32}$ and instituted provisions replacing joint and several liability with proportionate liability for certain securities fraud defendants, including outside directors facing Section 11 Securities Act liability and Rule 10b-5 defendants who did not knowingly violate the securities laws. ${ }^{33}$

The goal of the Litigation Reform Act's largely procedural reforms is clear: to design a filter that allows meritorious claims of fraud to proceed while blocking frivolous claims. ${ }^{34}$ To the extent the Litigation Reform Act succeeds, it should be commended. Empirical evidence does support the contention that much securities litigation before the Litigation Reform Act was frivolous. ${ }^{35}$

See, for example, D. Rosenberg and S. Shavell, A Model in Which Suits Are Brought for Their Nuisance Value, 5 Intl Rev L \& Econ 3, 3-4 (1985) (developing a formal model of nuisance suits based on the plaintiffs' ability to exploit a significant initial cost advantage in conducting a lawsuit); Lucian A. Bebchuk, Suing Solely to Extract a Settlement Offer, $17 \mathrm{~J}$ Legal Stud 437, 437-41 (1988) (arguing that nuisance suits may bring positive returns to plaintiffs where defendants are uncertain whether they actually face a nuisance or meritorious suit).

${ }^{30}$ Pub L No 104-67, 109 Stat 737 (1995), to be codified at scattered sections of Title 15 of the United States Code (amending the Securities Act and the Exchange Act).

${ }^{31}$ See Section 102, Litigation Reform Act, enacting Section 27A, Securities Act, codified at 15 USCA \& 77z-2. See also Section 101, Litigation Reform Act, enacting Section 21D, Exchange Act, codified at 15 USCA § 78u-4. In August 1996, for example, the State of Wisconsin Investment Board attempted to take control of a securities class action against CellStar Corp. See Dean Starkman, Pension Fund To Test New Securities Law, Wall St J B7 (Aug 8, 1996). See also Dean Starkman, Calpers Wins New Role in Suit Against Grace, Wall St J B12 (Sept 12, 1996) (reporting that the California Public Employees Retirement System gained the lead role in a corporate waste suit against W.R. Grace \& Co.).

${ }^{2}$ See Section 27A, Securities Act, codified at 15 USCA § 77z-2. See also Section 102, Litigation Reform Act, enacting Section 21E, Exchange Act, codified at 15 USCA § 78u-5.

${ }^{33}$ See Section 201, Litigation Reform Act, enacting Section 21D(g), Exchange Act, codified at 15 USCA $\S 78 u-4$. The amount of proportionate liability is measured as the percentage of the total fault of all persons who caused or contributed to the plaintiffs loss attributable to a particular defendant. Id at $21 \mathrm{D}(\mathrm{g})(3)(\mathrm{A})$. See also William M. Kelly, Corporate Disclosure Practices After the Private Securities Litigation Reform Act of 1995, 923 PLI/Corp 405 (1996) (considering the implication of the Litigation Reform Act's forwardlooking statement safe harbors on various forms of corporate communication).

${ }^{3}$ See House Floor Debate, H 2760-65, 104th Cong, 1st Sess (Mar 7, 1995), in 141 Cong Rec H 42 (Mar 7, 1995). Any procedural reform must also focus on allowing meritorious claims to proceed. Otherwise, the easiest method of eliminating all frivolous suits would be to do away with antifraud liability altogether. Of course, to the extent any suits are merit-based, this will also totally remove any securities law deterrent against fraud.

${ }^{35}$ See generally James Bohn and Stephen Choi, Fraud in the New-Issues Market: Empirical Evidence on Securities Class Actions, 144 U Pa L Rev 903 (1996) (suggests 
Particularly for initial public offerings in certain industry groups that involved relatively larger offering amounts, securities fraud litigation was frequent and often suspect..$^{36}$ Frivolous litigation, however, is not confined to initial public offerings but may affect all types of securities market transactions. Issuers bear the possible expense of defending against frivolous litigation and settling such claims; ${ }^{37}$ issuers may also underprice their issues to reduce the possibility of frivolous litigation, raising the cost of capital. $^{38}$ The specter of a nuisance suit may also chill a company's voluntary release of information into the market. Finally, frivolous litigation weakens the deterrence against fraud; in the extreme, where issuers face liability regardless of whether any actual fraud occurred, antifraud liability no longer provides deterrence against fraud.

Regardless of the Litigation Reform Act's impact, frivolous suits undoubtedly will continue to prove costly to all companies considering issuing securities. Although still too early to evaluate its overall effect, one recent study reports that the number of securities fraud class actions has remained constant in federal courts while state court filings have actually increased. ${ }^{39}$ Moreover, none of the Litigation Reform Act's procedural reforms provides a "magic bullet." For example, it is unclear whether heightening the role of institutional investors will greatly reduce the incidence of nuisance suits. As with other purchasers in an offering, institutional investors also gain from extracting settlement money from the issuer after the issuer's stock price drops; institutional investors, therefore, may only act to ensure that plaintiff's attorneys share more of the windfall from nuisance suits with the purchasers of the offering. Although plaintiffs attorneys may consequently have less incentive to bring nuisance suits, their incentive is not eliminated and such suits may still occur.

suits correlate with higher quality underwriters); Janet Cooper Alexander, Do the Merits Matter? A Study of Settlements in Securities Class Actions, 43 Stan L Rev 497 (1991) (identifies non-merit-related outcomes in securities litigation settlements).

${ }^{36}$ See Bohn and Choi, $144 \mathrm{U} \mathrm{Pa} L \mathrm{Rev}$ at 940-43 (cited in note 35). This problem was particularly salient in the computer industry. Id at 943.

${ }^{37}$ In 1993 dollars, the expected cost to issuers of securities antifraud litigation was $\$ 145,000$. Id at 981 . Of course, not all litigation is frivolous; the direct cost of frivolous litigation, therefore, may be somewhat less than $\$ 145,000$.

${ }^{38}$ See Seha M. Tiniç, Anatomy of Initial Public Offerings of Common Stock, $43 \mathrm{~J}$ Fin 789, 798-800 (1988).

${ }^{39}$ See Dean Starkman, Securities Class-Action Suits Seem Immune to Effects of a New Law, Wall St J B12 (Nov 12, 1996) (reporting that a National Economic Research Associates study found no decline in the number of securities class-action filings in federal courts and a dramatic increase in state court filings after the Litigation Reform Act). 
Likewise, introducing proportionate liability for outside directors and Rule 10b-5 defendants while expanding safe harbors for forward-looking statements may also reduce the expected gain from a nuisance suit to plaintiff's attorneys. Where, however, those defendants still facing joint and several liabilityincluding non-outside director defendants under Section 11 and Rule 10b-5 defendants who knowingly commit fraud ${ }^{40}$-possess adequate financial resources, plaintiff's attorneys may still profit from nuisance suits alleging fraud in statements not protected under the forward-looking safe harbors. Even if such suits face a lower probability of success at trial, plaintiffs attorneys will gain from frivolous suits if defendants who are risk-averse or who seek to avoid the cost, distraction, or embarrassing publicity of a trial still choose to settle. ${ }^{41}$ Furthermore, those nuisance suits with the highest dollar amounts at stake will provide plaintiff's attorneys with the greatest return despite the reforms. Nuisance suits may thus persist as a major cost of raising capital. Additional reforms, focused more on the substantive level of antifraud liability, may prove necessary to curtail further the high cost of nuisance litigation. ${ }^{42}$

This Article proposes a fundamental shift in the substantive antifraud system toward a status-based antifraud regime for primary offerings. Antifraud liability provides one deterrent against fraud. To the extent that the probability of antifraud liability increases as the quality of a company's disclosures decreases, companies will have more incentive to ensure high quality in their securities filings and information disclosures. For example, companies that face a higher probability of a fraud suit after releasing blatantly false information will take into account the increased expected cost from such a suit when deciding whether to engage in fraud.

Other mechanisms also work to affect the incentive of companies and managers to make accurate and materially complete disclosures. The impact of these other mechanisms turns directly on the size and public following of the issuing company. Reform, therefore, may take advantage of the efficient market-where it exists-and other deterrents against fraud to tailor a more precise legal antifraud liability and thereby reduce the incidence of frivolous litigation. Tailoring antifraud liability based on an is-

\footnotetext{
${ }^{2}$ See Section 11(f), Securities Act, codified at 15 USCA § 77k(f); Section 21D(g)(2)(A), Exchange Act, codified at 15 USCA $\S 78 \mathrm{u}-4(\mathrm{~g})(2)(\mathrm{A})$.

${ }^{41}$ See note 29 (describing different theories of nuisance suit litigation).

12 See note 279 (noting that the Advisory Committee considered a number of different antifraud proposals).
} 
suer's status will also reduce judicial administrative costs and, because the frequency of nuisance litigation is diminished, paradoxically encourage more high-quality issues. This Part (a) discusses the range of different companies that may contemplate issuing securities into the market; (b) examines the alternative antifraud mechanisms which exist in this market; (c) proposes a possible status-based antifraud system; and finally (d) refines this status-based regime. Later Parts of the Article discuss the relationship between status-based antifraud liability and recent company registration proposals, arguing that status-based antifraud liability alone substantively introduces features of company registration into today's securities regime.

\section{A. Differentiating Companies}

Today's antifraud regime applies the same level of antifraud liability regardless of the size or market following of a particular company. When a company such as General Motors ("GM"), for example, conducts a seasoned offering and floats $\$ 100$ million worth of securities into the market with the assistance of several brand name underwriting houses, GM bears the identical level of antifraud liability-and thereby exposure to private litigation risks-as smaller companies. For instance, hypothetical Central Motors ("CM"), a recent startup that seeks an additional $\$ 10$ million in capital through an initial public offering with the help of its local underwriter, faces the same Section 11 level of liability as GM. Although the level of due diligence defense may vary depending on the type of company involved, ${ }^{43}$ issuers do not enjoy this defense and it is unclear to what extent due diligence requirements actually do change for different companies. ${ }^{44}$ Likewise, Rule 10b-5 liability extends to all companies regardless of size or market following: whether a fraudulent misstatement or omission comes from GM or CM, plaintiffs must demonstrate the same level of scienter, materiality, and other prerequisites to liability. ${ }^{45}$

${ }^{43}$ See Rule 176, Securities Act, 17 CFR § 230.176 (1996).

" See Coffee, 52 Wash \& Lee L Rev at 1175 (cited in note 11) ("At best, Rule 176 is an ineffective provision, which appears never to have produced a pre-trial dismissal in a reported case since its adoption more than a decade ago.").

${ }^{45}$ Proof of Rule 10b-5 liability may, however, differ for GM- and CM-type companies. Plaintiffs suing GM may rely on the fraud-on-the-market theory to presume reliance while CM investors may not. See Basic Inc v Levinson, 485 US 224, 241-47 (1988). This makes it easier to pursue a Rule 10b-5 action against GM-sized companies; as this Article discusses later, however, because GM faces more market-based antifraud deterrents than CM-type companies, this is exactly the opposite allocation of legal antifraud liability that investors would desire. 
In fact, a wide range of different companies exist in the market between GM- and CM-sized issuers. Companies vary widely in their operating history, the amount of capitalization they possess, the size of their liquid trading market, and the number of professional securities analysts that follow the companies' progress and market valuation. At one extreme, large, highly capitalized companies issue securities that trade in efficient markets. ${ }^{46}$ At the other extreme, relatively small, low-marketcapitalization companies issue securities that trade in illiquid markets. ${ }^{47}$ These companies enjoy the attention of only a few analysts, if any. Analysts and other securities professionals must expend a fixed amount of resources learning about a particular business and updating this information over time. If a company lacks a large market capitalization and thereby trades in an illiquid market, the ability of analysts to make a return on their information investment is limited, leading fewer analysts to follow the company. Because trades occur infrequently and few analysts exist to apply pressure on the market price of these illiquid securities, investors cannot rely on the secondary market price to incorporate all public information concerning the company. Investors in inefficient market companies, therefore, must turn to other sources of information in evaluating their investments or alternatively rely more heavily on the protections of antifraud liability.

The Securities Act already partially takes into account the range in the efficiency of trading markets for different companies' securities. Based on the likelihood that a company trades in an efficient market, the SEC partitions companies seeking registration into three groups: those eligible for Form S-1, S-2, or S-3 registration. ${ }^{48}$ Form S-3 companies must have engaged in at least

\footnotetext{
${ }^{46}$ See note 19 (describing the semistrong version of the efficient capital markets hypothesis).

"Companies listed in the "pink sheets" over-the-counter market, for example, often do not disclose any information to the SEC and rarely trade more than once a day. See Amy Dunkin, Going For the Green in the Pink Sheets, Bus Week 82, $82-83$ (Aug 19, 1996) (describing the pink sheets market and providing investment tips).

${ }^{*}$ Forms S-1, S-2, and S-3, Securities Act, 2 Fed Sec L Rptr (CCH) III 7121-26 (Oct 25, 1955); III 7141-46 (May 24, 1982); III 7151-55 (May 24, 1982) (instituting different registration forms for the three company types). See also Proposed Comprehensive Revision to System For Registration of Securities Offerings, Securities Act Release No 6235, 45 Fed Reg 63693 (Sept 25, 1980) (proposing a three-tier registration framework). Small business issuers may also register securities under Forms SB-1 and SB-2. See Forms SB-1, SB-2, Securities Act, 2 Fed Sec L Rptr (CCH) II 7312 (June 3, 1993); II 7313-14 (Aug 13, 1992) (creating separate registration procedure for companies with small business status). Foreign issuers may also issue securities under Forms F-1, F-2, and F-3. See Forms F-1, F-2, F-3, Securities Act, 2 Fed Sec L Rptr (CCH) III 6951-56 (Dec 4, 1982); II 6961-66 (Dec 4, 1982); III 6971-74 (Dec 4, 1982) (creating separate registration process for foreign issu-
} 
one year of Exchange Act reporting and, for primary distributions of non-investment-grade securities, enjoy a market capitalization (by nonaffiliates) of at least $\$ 75$ million, among other requirements. ${ }^{49}$ Companies that meet the S-3 qualifications receive the greatest presumption of efficient market status and may incorporate the largest amount of information by reference from their most recent Exchange Act filings into the Securities Act registration statement. ${ }^{50}$ Similarly, S-2 companies must have engaged in at least three years of Exchange Act reporting, but do not have to meet any market capitalization requirements. ${ }^{51}$ The Securities Act therefore maintains a lower presumption of efficient market status and consequently allows less incorporation by reference. ${ }^{52}$ Finally, S-1 companies carry no presumption of efficient market trading and are consequently denied the ability to incorporate by reference. ${ }^{53}$

The same efficient market rationale that supports incorporation by reference also justifies varying antifraud liability level by the market status of companies. Companies with extensive mar-

ers). Although important, these alternate forms are not essential to the analysis of this Article and are consequently not examined.

${ }^{9}$ See Form S-3 (cited in note 16).

${ }^{50}$ Form S-3 issuers must include transaction-related information in the Form S-3 prospectus, involving information regarding the use of proceeds, the underwriters involved in the transaction, the selling security-holders, the issue price and offering dilution, and other information related to the transaction. Outside of the transaction-related information, S-3 issuers may incorporate almost all other information concerning the company directly from Exchange Act filings. S-3 issuers, nevertheless, must update the prospectus with material information not already in an Exchange Act filing. See Form S-3 (cited in note 16). See also Bloomenthal and Holme, Roberts \& Owen, Securities Law Handbook $\S 5.05[1][a]$ (cited in note 27) (summarizing information and eligibility requirements of Form S-3).

${ }^{51}$ See Form S-2 (cited in note 16).

${ }^{52}$ Form S-2 issuers must include the same transaction-related information as S-3 issuers in the Form S-2 prospectus. In addition, S-2 issuers must list basic company-related information-including standardized financial statements, the management discussion and analysis section, a brief description of the registrant's business, and market and dividend information-in either the prospectus or separately in the latest annual report sent with the prospectus to investors. Form S-2 issuers are allowed, however, to incorporate by reference more detailed company-related information from Exchange Act filings. See Form S-2 (cited in note 16). See also Bloomenthal and Holme, Roberts \& Owen, Securities Law Handbook $\$ 5.05[1][a]$ (cited in note 27) (summarizing information and eligibility requirements of Form S-2).

${ }^{53}$ Form S-1 companies must include-without incorporation by reference-all transactional, basic company, and detailed company information in the prospectus. The detailed company information includes a detailed description of the business, any legal proceedings involving the issuer, the officers and directors, transactions with management, the security ownership of 5 percent beneficial shareholders, and executive compensation. See Form S-1 (cited in note 16). See also Bloomenthal and Holme, Roberts \& Owen, Securities Law Handbook § 5.05[1][a] (cited in note 27) (summarizing information and eligibility requirements of Form S-1). 
ket capitalization and a large investment analyst following possess different incentives to engage in misleading disclosures than smaller companies with shorter operating histories and less public presence in the securities market. The next Section discusses these market-based antifraud mechanisms, explains how these market mechanisms vary with the capitalization of the issuer, and examines how legal antifraud liability should respond to this variation. Of course, the SEC's current S-1, S-2, and S-3 framework only roughly captures the differences across companies. ${ }^{54}$ As a proxy for the degree of efficiency with which a company's securities may trade, the framework may suffer from typical overand under-inclusion problems plaguing all bright-line rules. The focus of this Article, however, is not on reforming the exact breakdown of companies among different categories of efficiency, but rather on taking into account these differences among companies as applied to the operation and impact of antifraud rules. Therefore, although somewhat arbitrary, the SEC's S-1, S-2, S-3 division is taken as given for the remainder of the Article. However, nothing in the analysis depends on this particular categorization; what is important is that regulators understand that a range of companies does exist regardless of the particular categories among which companies today are divided.

\section{B. Market-Based Antifraud Mechanisms}

Antifraud legal liability does not exist in a vacuum. When deciding upon their disclosure strategy in the context of a primary transaction, companies must take into account not only the prospect of antifraud legal liability but also market-based mechanisms that deter fraud. Most companies do not issue misleading disclosures or omit material information without some financial reason to do so. In particular, companies (or their managers) may wish to elevate artificially their share price either during a public offering or other primary transaction. Managers, in maximizing both their own welfare and the company's profits, will consider (1) the availability of other contradictory public information; (2) the impact of fraud on their own personal reputations; and (3) the existence of reputational intermediaries who may fail to corroborate the managers' disclosures..$^{55}$ Each of these

\footnotetext{
${ }^{s}$ See James D. Cox, Robert W. Hillman, and Donald C. Langevoort, Securities Regulation: Cases and Materials 248-49 (Little, Brown 1991) ("Cox, Casebook") (noting that many companies that qualify for Form S-3 nevertheless fail to receive much attention from institutional investor or brokerage firm analysts).

ss Compare Jennifer H. Arlen and William J. Carney, Vicarious Liability for Fraud on Securities Markets: Theory and Evidence, 1992 U Il L Rev 691, 701-03 (arguing that
} 
mechanisms, as well as the importance of the market status of the issuer involved, are discussed below.

\section{Information constraints.}

Investors evaluating the information disclosures from a company take into account not only the represented value of the offered securities and other disclosures from the company, but other publicly available information as well. The investing public can tap into a greater amount of information regarding the assets, activities, and plans of larger companies with longer operating histories. Importantly, larger, well capitalized companies also have a greater number of securities analysts that specialize in assessing the value of these companies. ${ }^{56}$ Such analysts corroborate the information released from the company and play an important role in limiting the ability of managers to misstate the value of their companies. In contrast, smaller, lesser known companies have a greater ability to mislead the public. Little alternative public information may exist, for example, on small companies trading in the over-the-counter market. ${ }^{57}$ Moreover, few analysts follow smaller, over-the-counter companies closely enough to assess the company's information disclosures. ${ }^{58}$ Such

"managers of ailing firms commit Fraud on the Market in an attempt to save their jobs, by using the period of the fraud to turn the firm around").

${ }^{56}$ See John C. Coffee, Jr., The SEC and the Institutional Investor: A Half-Time Report, 15 Cardozo L Rev 837, 848 (1994) (providing statistics that institutional investors held 23 percent of outstanding equity in the United States in 1955, 38 percent in 1981, and over 50 percent in 1990); New York Stock Exchange, Fact Book for the Year 1995, at 57 (1996) (reporting that the percentage of U.S. equities held by U.S. pension funds alone increased from 0.8 percent in 1950 to 22.2 percent by 1995).

${ }^{57}$ Unless over-the-counter companies have greater than five hundred shareholders of a class of securities and net assets over $\$ 10$ million or recently conducted a registered offering, they will escape the Exchange Acts periodic reporting requirements. See Section 13(a), Exchange Act, codified at 15 USC \& 78m(a) (referring to Section 12, Exchange Act, for definition of issuers required to file); Section 15(d), Exchange Act, codified at 15 USC § 78o(d) (same); Section 12(g), Exchange Act, codified at 15 USC \& 78l(g) (exempting issuers with fewer than 500 shareholders of a class of securities and less than $\$ 1$ million in assets); Rule 12g-1, Exchange Act, 17 CFR § 240.12g-1 (1996), as amended by Relief and Reporting by Small Issuers, SEC Exchange Act Release No 37,157, [Current] Fed Sec L Rptr (CCH) II 85,801 (May 17, 1996) (extending the exemption from the requirement to file under Section 12 of the Exchange Act for companies with less than $\$ 10$ million in assets). Furthermore, smaller capitalized companies may have fewer incentives to release information voluntarily into the market to the extent they trade only infrequently and are followed by relatively few analysts.

${ }^{58}$ Institutional investors, for example, accounted for nearly 74 percent of the trading volume on the NYSE in 1988 but only 43 percent of the volume on NASDAQ. See Cox, Casebook at 10 (cited in note 54) (citing Securities Industry Association Research Department, Trends: An Analysis of Emerging Trends in the Securities Industry (1989)). Moreover, some evidence exists that less than one thousand of the more than ten thousand Exchange Act reporting companies are followed by one or more investment analysts. 
companies, therefore, can more easily misstate their value. S-1 companies, for instance, are more likely to have a smaller market following and less publicly available information compared to S-3 companies. For S-3 companies, therefore, antifraud legal liability may result in a lower incremental reduction in fraud simply because the S-3 companies have less room to misstate their value credibly. In contrast, because S-1 companies have much greater leeway to make misrepresentations or omissions, legal antifraud liability has a greater impact in deterring fraud by these companies.

Conversely, others may argue that small issuers with securities trading in an illiquid market actually attract more analysts to the extent these analysts may obtain a greater return from their research investment. Analysts may receive more from their research investment because illiquid, small companies tend to be priced relatively farther away from their true fundamental value; uncovering an undervalued small company, therefore, may provide the analyst with a disproportionately large profit. Indeed, if all markets were the same for all securities and all issuers, then analysts would distribute themselves uniformly across all securities until the same level of price inefficiency existed. If this did not occur, then some analysts would shift into relatively more price-inefficient markets to obtain higher profits. However, not all securities and issuers are the same. Larger companies with more securities and capitalization have more sophisticated investors and analysts following them for several reasons. First, investment analysis of a company requires a certain fixed cost investment regardless of the market capitalization of the company; therefore, an investment analyst is better able to spread the costs of such research for companies with a greater capitalization. Second, many sophisticated investors have short-term horizons and therefore may not be willing to invest in an illiquid market, even for undervalued securities. For such investors, achieving a relatively quick short-term return is more valuable than the potentially greater gain from a long-term investment to the extent the long-term investment also places on the investor the risk that the investment may suffer a loss before achieving any profit and, moreover, forces the investor to forgo other valu-

See Cox, Casebook at 41 (cited in note 54) (citing Report of the Advisory Committee on Corporate Disclosure to the Securities and Exchange Commission xviii, 40-42 (1977)). See also Brad M. Barber, Paul A. Griffen, and Baruch Lev, The Fraud-on-the-Market Theory and the Indicators of Common Stocks' Efficiency, 19 J Corp L 285, 303 (1994) (reporting that firms on NASDAQ for the 1984-1990 period had on average 0.68 analysts following the firm and 15.21 institutional investor owners). 
able investments due to capital constraints. ${ }^{59}$ Finally, analysts tend to herd with other analysts in their research and investment choices. Analysts may herd to the extent that doing better than the average analyst is not rewarded as much as doing worse is punished..$^{60}$ The desire to herd, in turn, leads analysts to avoid poorly followed issuers where the possibility of herding with other analysts is low.

\section{Reputational constraints.}

Managers may find themselves constrained by reputational concerns. For example, some managers gain from developing a reputation for honesty and therefore refuse to condone fraudulent disclosures to preserve this reputation. The gain from an honest reputation may translate into monetary, social, or psychological returns. Other companies may pay more to managers with a greater reputation for honesty to signal the quality of the company's enterprise or upcoming offerings. ${ }^{61}$ Realizing this, managers may resist fraudulent disclosures to increase their chance at obtaining one of these high-paying jobs. ${ }^{62}$ Managers may also gain from the greater social standing accompanying an

\footnotetext{
${ }^{59}$ Sophisticated investment arbitrageurs may face a credit constraint to the extent outside lenders are unsure of a particular arbitrageur's abilities; outside lenders may therefore give the arbitrageur only a limited amount of capital at an unfavorable rate until they become more sure of the arbitrageur's abilities. As a result of this credit constraint, arbitrageurs face an opportunity cost in having money tied up in a long-term investment: the arbitrageur may lack the ability to take advantage of valuable interim opportunities due to the lack of funds. Arbitrageurs, therefore, may try to convince outside investors of their financial prowess quickly to raise more funds through good performance in relatively short-term investments. See Andrei Shleifer and Robert W. Vishny, Equilibrium Short Horizons of Investors and Firms, 80 Am Econ Rev 148, 149-50 (Papers and Proceedings, May 1990).

${ }^{\infty}$ This may occur where others are trying to judge an analyst's investment ability that is not generally known to the market. To the extent "smart" investors act in a correlated manner-e.g., they all realize a particular stock is in fact a bad investment and refuse to invest--then acting differently from the group may signal to the market that a particular analyst in fact is not "smart". Therefore even analysts with some special insight into the value of a security may ignore this insight and simply go along with the group to the extent doing better than the group results in a greater investment return while doing worse may result in being branded a bad analyst, resulting in a loss of investment funds and possibly employment. See David S. Scharfstein and Jeremy C. Stein, Herd Behavior and Investment, 80 Am Econ Rev 465, 465 (1990).

${ }^{61}$ See Lynnette Khalfani, As Employers Focus on Ethics Training, Cottage Industry for Consultants Grows, Wall St J B4 (Aug 12, 1996) (detailing how several companies are turning to ethics consultants to boost their internal ethics programs); Randy N. Myers, At Martin Marietta, This Board Game Is Lesson in Ethics, Wall St J A52 (Sept 25, 1992) (detailing Martin Marietta's push to raise ethics awareness among its employees).

${ }^{\circ}$ See also Arlen and Carney, $1992 \mathrm{U}$ III L Rev at 702 (cited in note 55) (arguing that the threat of termination of employment normally provides managers with strong incentives not to commit fraud).
} 
upstanding, honest reputation. ${ }^{63}$ Involvement with a misleading disclosure may thus not only taint a manager's business prospects but also her standing with friends and social organizations. Finally, managers may prefer to act ethically and treat ethical behavior as a worthwhile goal.

Importantly, the incentive for managers to engage in reputation building is greatest where the manager is under the greatest public scrutiny. More public scrutiny results in a higher correlation between the manager's actions and her public reputation. Companies with greater public following or visibility consequently will enjoy the highest level of managerial reputation incentives to remain truthful and complete in their disclosures. Even where no legal action is ever brought against a company making misleading disclosures, managers associated with a highly visible disclosure may experience a decrease in their labor market reputations. Applying this insight to the current Securities Act disclosure regime, S-3 company managers gain the most from maintaining truthful company disclosures. Accordingly, the incremental gain in fraud deterrence from increased antifraud legal liability is diminished in the case of S-3 companies.

\section{Gatekeeper constraints.}

Third parties associated with an offering may act to signal the quality and value of a company and its disclosures to investors. Academics deem a third party acting in this manner as a "gatekeeper" or "certifier." ${ }^{\text {"64 }}$ Certifiers reduce the asymmetric information problem between investors and issuers. Through association with a certifier, higher value firms are able to signal credibly their value to investors. Investors view such a signal as credible so long as (a) the certifiers actually possess the necessary screening expertise to distinguish among different value issuers and (b) the certifiers have adequate incentives to execute faithfully their certification duties. Due diligence requirements in Section 11, for instance, provide one incentive for certifiers to perform their gatekeeping function. ${ }^{65}$

$\varpi$ But see Dawn Blalock, For Many Executives, Ethics Appear to Be a Write-Off, Wall St J C1 (Mar 26, 1996) (citing evidence that a large number of business professionals would commit securities fraud under certain circumstances).

6 See generally Reinier H. Kraakman, Corporate Liability Strategies and the Costs of Legal Controls, 93 Yale L J 857, 888-96 (1984). See also Stephen J. Choi, Certification Intermediaries: Market Lessons for Gatekeepers (on file with U Chi L Rev) (arguing that in many cases, legal liability is unnecessary and detrimental to the role of third-party intermediaries to signal quality to investors or consumers).

s Due diligence sets both a certain type and quantity of screening that must occur before third parties are free from Section 11 liability. See Escott $v$ BarChris Construction 
Other factors may also drive third-party intermediaries. ${ }^{66}$ In particular, market-based mechanisms induce some third parties to act as certifiers. ${ }^{67}$ Imagine three sets of parties-issuers, investors, and certifiers-in a world without antifraud liability. All other things being equal, issuers desire to sell securities to investors at the highest price possible. Some issuers, therefore, may engage in fraud to raise their issue price. Rational investors, however, realize this incentive and will discount the securities of all issuers accordingly. Issuers that somehow credibly signal their true value to investors will obtain a lower discount for their shares and thereby raise greater offering proceeds. Association with a third party acting as a gatekeeper against fraud provides issuers at least one avenue to signal their value credibly. ${ }^{68}$ Gatekeepers that screen accurately for fraud and do so faithfully, therefore, are more valuable to issuers and may demand a greater compensation.

Indeed, left only to market-based incentives, a range of different quality reputational intermediaries may arise. Suppose a particular underwriter, for example, has a reputation for relatively high-quality screening for fraud. Both high-quality and relatively lower-quality issuers may seek to retain the services of the high-quality underwriter. In fact, to the extent investors are otherwise unable to distinguish between the high- and lowquality issuers, both types of issuers gain the same amount from associating with the high-quality underwriter: associated issuers are considered high-quality while non-associated issuers are considered lower-quality. The high-quality underwriter, however, is not indifferent between selecting either type of firm. To the ex-

Corp, 283 F Supp 643, 682-97 (S D NY 1968); Rule 176, Securities Act, 17 CFR § 230.176 (1996).

${ }^{66}$ The Advisory Committee as a whole and Coffee in particular recognize the gatekeeping role that underwriters and other third parties play. See Coffee, 52 Wash \& Lee L Rev at 1169 (cited in note 11). They ignore, however, the market-based incentive for underwriters to perform this function.

"Coffee, among others, has argued that shelf registration has hurt the ability of underwriters and auditors to conduct their due diligence investigations. See id at 1170 ("Perhaps irretrievably, underwriters have lost their role as reputational intermediaries in shelf registrations."). This view, however, ignores the market incentives of issuers and underwriters to find a way for underwriters to perform a certification function to the extent investors value certification. The drop in due diligence investigations, therefore, may reflect more the low value that investors place on the legal level of due diligence and less the failing of the certification mechanism.

${ }_{\infty}^{\infty}$ Other means of providing investors with a credible signal of value are possible. For example, companies making repeated trips to the capital markets for financing may develop a reputation for honest dealing with investors. This reputation, in turn, is credible to the extent investors realize that companies have an incentive to maintain their reputation in order to keep the door open for further capital market financing. 
tent the high-quality underwriter selects mainly low-quality firms, investors eventually will reduce the reputation of the underwriter, depreciating the value to issuers of associating with the underwriter in the first place. As a result, issuers will no longer seek to employ the services of the underwriter (or will do so only at a lower fee). High-quality underwriters, therefore, will seek to service only the highest-quality firms. Likewise, the next highest-quality of underwriters will associate with the nexthighest-quality firms.

In this manner, a sorting will take place whereby the different range of underwriter quality will in turn signal a different range of quality issuers to the market. Through a diverse pool of certifiers, therefore, investors may obtain information on the relative quality and risk involved in a wide variety of different firms in the market based on how these firms sort themselves out among the different certifiers. Not only are investors better protected as a result, but companies engaging in fraud are more likely to receive a lower return for their efforts, reducing the ex ante incentive of such companies to engage in fraud.

The market, however, may not always work in this separating fashion. In particular, there is always the risk that a thirdparty intermediary may collude with the issuer and "certify" an issue known to be fraudulent. In fact, the higher the reputation of the intermediary, the more both the issuer and the certifier have to gain from false certification. Legal liability may therefore act as a means to bond third-party intermediaries to remain faithful in the screening. However, market-based bonding mechanisms also exist. In particular, high-quality certifiers often are repeat players with large investments in their screening capabilities; for such intermediaries, the loss of this investment and reputation far outweighs the gain from assisting any one issuer in committing fraud. Underwriters, for example, may invest in operations around the world and hire more personnel to staff these operations. ${ }^{69}$ Greater capacity increases the cost to certifiers from a loss in credibility with investors, thereby deterring certifiers from cooperating with issuers to mislead investors in any one offering. Nevertheless, legal liability may have some room to help smaller, lower-quality certifiers bond themselves to remaining faithful. Note, however, that this argument falls far short of a general third-party legal liability regime. In fact, im-

${ }^{69}$ See Fred R. Bleakley, U.S. Firms Shift More Office Jobs Abroad: But Most are Filled with Local Hires, Not Americans, Wall St J A2 (Apr 22, 1996) (describing the overseas expansion of white-collar jobs for many companies, including Goldman Sachs). 
posing the same level of legal liability on all certifiers may do more harm than good, particularly where it raises costs unnecessarily and levels the range of different quality certifiers that investors depend on to determine the quality of the issue for pricing purposes. ${ }^{70}$ Where all certifiers screen with the same level of legally imposed accuracy, investors lose the signaling information certification provides on the relative quality of different issuers.

Some adjustment in the level of third-party liability based on the quality of the third-party intermediary, therefore, may improve their gatekeeper function. Moreover, the quality of thirdparty certification will tend to vary systematically with the market capitalization and following of the issuing companies. Investment in certification screening quality requires large capital and ongoing expenditures. As a result, only a few securities professionals may undertake this expense, leading to a relatively small pool of high-quality certifiers. ${ }^{71}$ In addition, to recoup these expenses, these professionals may charge relatively high fees for their services. Among even high-quality issuers, for example, only those companies with enough market capitalization on which to spread the higher fees the high-quality certifiers charge will associate with the high-quality certifiers. Moreover, the cost of certification may be cheaper for well followed issuers with a relatively long operating history to the extent the certifier has some track record with which to assess the companies' present status. Smaller companies therefore may simply be unable to afford the cost of a certifier that performs a stringent level of review; alternatively, certifiers may have less incentive to expend resources in screening these companies. As a result, smaller companies may be forced to employ lesser-known certifiers that may have less to lose from gambling with their reputation, and as a result may voluntarily choose to ignore signs of fraud. Some level of third-party liability, therefore, may be necessary to bond certifiers that service smaller companies or companies conducting smaller offerings to remain faithful to their screening and signaling functions. ${ }^{72}$

\footnotetext{
${ }^{70}$ For a discussion of the defects in the market-based certification mechanism and the role of legal intervention to bolster the certification market, see Choi, Certification Intermediaries at $39-60$ (cited in note 64 ).

${ }^{7}$ See Richard Carter and Steven Manaster, Initial Public Offerings and Underwriter Reputation, $45 \mathrm{~J}$ Fin 1045, 1054-56 (1990) (constructing a ranking of underwriter quality based on their relative positions in tombstone advertisements for offerings from January 1979 to December 1983).

${ }^{72}$ See, for example, Rule 176, 17 CFR § 230.176 (1996) (providing that some specified factors are "relevant circumstances" in determining whether a party has satisfied its due
} 


\section{A Status-Based Antifraud Proposal}

Has the time come for a shift toward a status-based antifraud liability regime? The alternative market-based antifraud mechanisms vary in strength largely based on the market capitalization and public following of the issuing company. Tailoring antifraud legal liability to apply most strongly where other antifraud mechanisms are weakest would result in the highest value application of judicial resources. Tailoring would reduce the cost of maintaining the antifraud liability system-including judicial administrative costs, litigation costs, and the costs of frivolous litigation-without a correspondingly large drop in antifraud deterrence due to the strong presence of alternative antifraud devices. Several additional reasons also argue for a status-based antifraud system.

First, even with the same formal level of antifraud liability, private enforcement is more vigorous for S-3 companies. Simple economics drives this observation. The incentives of plaintiff's attorneys largely propel securities class actions. A meritorious fraud action, for example, will not be brought where plaintiff's attorneys are not assured an adequate return on their litigation expenses. Even after the Litigation Reform Act, private enforcement still depends on the aggregating role of plaintiff's attorneys, who amass the interests of disparate shareholders with little individual incentive to pursue litigation. Plaintiff's attorneys will agree to manage class actions only to the extent they recover their expenses and turn a profit. Furthermore, the costs of litigation tend to be relatively independent of the actual size of the offering amount in question. ${ }^{73}$ To prove a successful case for issue sizes of $\$ 1$ million to $\$ 100$ million, plaintiffs attorneys must conduct depositions, go through discovery, obtain class certification, and undertake other procedural aspects of litigation. Even meritbased plaintiff's attorneys thus have a greater economic incentive to pursue larger claim cases. Antifraud liability should adjust for these incentives, increasing the return for merit-based attorneys pursuing smaller companies for fraud, as would occur in a statusbased antifraud system.

diligence defense under Section 11(c) of the Securities Act). But see Coffee, 52 Wash \& Lee $\mathrm{L}$ Rev at 1160 n 46; 1175 n 90 (cited in note 11) (noting that Rule 176 has not been interpreted by any court and that the bar largely considers Rule 176 ineffective).

${ }^{73}$ See, for example, Bohn and Choi, $144 \mathrm{U} \mathrm{Pa} \mathrm{L} \mathrm{Rev} \mathrm{at} \mathrm{936-37} \mathrm{(cited} \mathrm{in} \mathrm{note} \mathrm{35)}$ (providing evidence that smaller offerings less frequently face private securities fraud litigation, and attributing this phenomenon to the plaintiffs attorneys' fixed costs of litigation). 
Second, where plaintiff's attorneys pursue frivolous litigation, the incentives of such attorneys result in a disproportionately larger cost for those companies conducting larger offerings. Frivolous-suit plaintiff's attorneys will target companies with relatively large amounts of cash as a means of boosting the amount of money they may possibly obtain from settlement. To the extent that larger, more highly capitalized companies possess a greater amount of liquid resources to satisfy a judgment or settlement, tend to conduct larger offerings, or else own greater amounts of securities litigation liability insurance, these companies more frequently will become the target of frivolous suits. ${ }^{74}$ Reducing antifraud liability for larger companies may result in greater numbers of such companies seeking to raise capital through securities offerings rather than more traditional bank financing. Where market-based antifraud mechanisms work effectively to deter fraud even in the absence of legal liability, the number of quality issues from large companies will increase. Paradoxically, reducing antifraud liability raises the average quality level of issues presented to investors.

From the standpoint of fraud deterrence, therefore, varying the level of antifraud liability based on the status of the company may present a more efficient use of judicial resources and improve the quality of capital market offerings. Furthermore, a status-based antifraud regime may be accomplished through a simple reform to the existing Securities Act regime. This Article, for example, proposes that reform track the same differentiation that currently exists within the Securities Act: S-3 companies would be presumed to face the greatest array of alternative deterrents against fraud and would accordingly receive the lowest level of antifraud liability. Similarly, S-2 and S-1 companies would receive a reduced presumption of market following and increasingly greater levels of antifraud liability.

Antifraud liability, of course, incorporates several different elements. For each of the major antifraud provisions in the securities laws, courts must deal with different materiality, reliance, causation, and scienter requirements. Section 11, for example, requires no showing of reliance, causation, or scienter but does require a material misstatement or omission for liability to attach. ${ }^{75}$ Similarly, Section 12(a)(2) liability applies only to material misstatements and omissions; in contrast to Section 11, how-

\footnotetext{
"Id. Note, however, that to the extent that smaller issuers possess securities liability insurance, frivolous plaintiff's attorneys may also target the smaller issuers.

${ }^{75}$ See Section 11(a), Securities Act, codified at 15 USC § 77k(a).
} 
ever, Section 12(a)(2) requires some amount of causation. ${ }^{76}$ Furthermore, Section 12(a)(2) provides a negligence standard of sorts in the form of a defense against liability: the defendant has the burden of proof to show that "he did not know, and in the exercise of reasonable care could not have known, of such untruth or omission" to escape liability. ${ }^{77}$ Finally, Rule 10b-5 similarly contains a material misstatement or omission requirement. ${ }^{78}$ Reliance and causation are required, but plaintiffs may use the "fraud-on-the-market" theory to demonstrate reliance. ${ }^{79}$ In contrast to both Sections 11 and 12(a)(2), however, Rule 10b-5 imposes a scienter requirement. ${ }^{80}$

The major antifraud provisions also differ in their specification of who may bring suit as private plaintiffs and who may be sued as potential defendants. Section 11 provides liability only for those who purchased securities sold pursuant to a registration statement; ${ }^{81}$ Section 11 also lists a closed set of possible defendants including the issuer, directors of the issuer, professionals who certified a portion of the registration statement, and all underwriters involved in the offering. ${ }^{82}$ Under Section 11(b), furthermore, all defendants except the issuer enjoy a due diligence defense. $^{83}$ Section 12(a)(2) provides liability generally for purchasers of securities; in contrast to Section 11, however, purchasers may bring suit under Section 12(a)(2) only against those with whom they enjoy privity or those who engaged in a solicitation of

${ }^{76}$ See Section 12(a)(2), Securities Act, codified at 15 USCA \& 771(2); Sanders $v$ John Nuveen \& Co, 619 F2d 1222, 1225 (7th Cir 1980) (stating that § 12(a)(2) "requires some causal connection between the misleading representation or omission and plaintiffs purchase").

${ }^{\pi}$ Section 12(a)(2), Securities Act, codified at 15 USCA § 771(2).

${ }^{73}$ See Rule 10b-5, Exchange Act, 17 CFR § 240.10b-5 (1996); Basic Inc v Levinson, 485 US 223, 230-32 (1988).

${ }^{79}$ See Basic, 485 US at 247 ("Because most publicly available information is reflected in market price, an investor's reliance on any public material misrepresentations, therefore, may be presumed for purposes of a Rule 10b-5 action.").

${ }^{80}$ See Ernst \& Ernst v Hochfelder, 425 US 185, 201-14 (1976) (language and history of Section 10(b) support scienter requirement); Gray v First Winthrop Corp, 82 F3d 877, 884 (9th Cir 1996) ("In order to meet the scienter requirement [of Rule 10b-5], plaintiffs must show either knowing or reckless conduct on the part of defendants.").

${ }^{81}$ See Section 11(a), Securities Act, codified at 15 USC § 77k(a).

${ }^{82}$ See Section 11(a)(1)-(5), Securities Act, codified at 15 USC $\S 77 \mathrm{k}(a)(1)-(5)$. See also Section 6, Securities Act, codified at 15 USC $\$ 77 f$ (requiring that the issuer and its principal executive officer, financial officer, and the majority of the board of directors sign the registration statement).

See Section 11(b), Securities Act, codified at 15 USC \& 77k(b). The nature of the due diligence defense depends on the relationship between the defendant and the issuer. Escott v BarChris Construction Corp, 283 F Supp 643, 682-97 (S D NY 1968); Rule 176, Securities Act, 17 CFR § 230.176 (1996). 
an offer to buy. ${ }^{84}$ Lastly, Rule 10b-5 provides a private remedy for all purchasers and sellers against any party that perpetrates a fraud "in connection with the purchase or sale of securities." Because the Supreme Court abolished aiding and abetting liability under Rule $10 \mathrm{~b}-5,{ }^{86}$ however, third parties face an uncertain scope of liability. ${ }^{87}$

Finally, antifraud provisions may differ in the amount of damages available as well as possible defenses against liability. ${ }^{88}$ Section 11, Section 12(a)(2), and Rule 10b-5, however, each provide defendants the ability to prove that the plaintiffs' lossusually measured in terms of a drop in the secondary market price-was caused by factors other than the defendants' misleading misstatement or omission. ${ }^{89}$

A status-based antifraud regime must correlate the variation among these elements with (1) the availability of alternative antifraud mechanisms, and (2) the company's size and trading status. In particular, the demands of materiality, scienter, and third-party defendants and their defenses should vary with the company's status when determining liability in such a regime.

\section{Materiality.}

Materiality serves as a common element for all the antifraud provisions, determining the scope of disclosure subject to antifraud liability. The materiality requirement demands an untrue statement of a material fact or an omission of a material fact

${ }^{84}$ See Section 12(a)(2), Securities Act, codified at 15 USCA $\S 771(a)(2) ;$ Sanders, 619 F2d at 1226 ( $[$ [T] he statute explicitly requires privity between plaintiff-purchaser and defendant-seller.").

${ }^{85}$ Rule 10b-5, Exchange Act, 17 CFR $\S 240.10 b-5$ (1996). Courts have found activities by defendants to be "in connection" with the purchase or sale by the plaintiff of a security in cases where the defendant merely disseminated false or misleading statements into the market through a press release or other means reasonably calculated to affect investors trading the security on the open market. See SEC v Texas Gulf Sulphur Co, 401 F2d 833, 858-61 (2d Cir 1968).

${ }^{86}$ See Central Bank of Denver $v$ First Interstate Bank of Denver, 511 US 164, 191 (1994) (holding that plaintiffs may not maintain an aiding and abetting suit under Section 10(b) of the Exchange Act).

${ }^{87}$ Third parties may still face Rule $10 \mathrm{~b}-5$ liability as "indirect" primary violators.

88 Prior to 1991, the antifraud provisions also differed in the statute of limitations to file a claim. In 1991, however, the Supreme Court extended the same statute of limitations contained in Section 13 of the Securities Act to Rule 10b-5 actions. See Lampf, Pleva, Lipkind, Prupis \& Petrigrow v Gilbertson, 501 US 350, 359 (1991).

${ }^{8}$ See Section 11(e), Securities Act, codified at 15 USC $\S 77 \mathrm{k}(\mathrm{e})$; Section 12(a)(2), Securities Act, codified at 15 USCA \& 771(a)(2); Jon Koslow, Note, Estimating Aggregate Damages in Class-Action Litigation Under Rule 10b-5 for Purposes of Settlement, 59 Fordham L Rev 811, 817 \& n 27 (1991) ("[T] he connected elements of materiality, reliance and causation require that damages calculations under Rule 10b-5 exclude the effects of market fluctuations unrelated to the fraud or misrepresentation."). 
necessary to make the statements therein not misleading. ${ }^{90}$ Even for information that otherwise would be considered material, however, the securities laws provide at least two different safe harbors under Rule $\mathbf{1 7 5}$ of the Securities Act ${ }^{91}$ and the new Section 27A of the Securities Act, enacted as part of the Litigation Reform Act. ${ }^{22}$ Although similar in approach, the safe harbors under Rule 175 and Section 27A are not identical. Section 27A applies generally to all forward-looking statements regardless of whether the statement is oral or contained in a written document; ${ }^{93}$ Rule 175 applies only to forward-looking statements present in a specified Exchange Act filing or in a registration statement filed under the Securities Act. ${ }^{94}$ Furthermore, Rule 175 requires that the issuer both have a reasonable basis and act in good faith. ${ }^{95}$ Section 27A, on the other hand, provides a safe harbor for an issuer that either makes meaningful cautionary statements or succeeds in defending against the charge that it had actual knowledge of the misleading statement or omission. ${ }^{96}$ Finally, although wider in scope, the safe harbor in Section 27A

${ }^{90}$ Although termed "materiality" in this Article, this element actually consists of two parts: there must be present a (1) material misstatement or omission of a (2) fact. See Virginia Bankshares, Inc $v$ Sandberg, 501 US 1083, 1090-98 (1991) (holding that even if statements were material, they must still consist of "facts" to fall within the scope of Rule 14a-9 proxy solicitation antifraud liability). For the purposes of this Article, however, all that is important is that the material fact requirement together with the forward-looking statement safe harbors determine the scope of statements within the reach of antifraud liability.

9117 CFR § 230.175 (1996). Rule 3b-6 of the Exchange Act provides a parallel provision for the Exchange Act. See 17 CFR \& 240.3b-6 (1996).

${ }^{2}$ Section 27A, Securities Act, codified at 15 USCA \& 77z-2. Section 21E of the Exchange Act provides a parallel provision for the Exchange Act. See Section 21E, Exchange Act, codified at 15 USCA § 78u-5. In addition to Rule 175 and Section 27A, courts have also constructed a carve-out from materiality under the bespeaks caution doctrine. See Jonathan B. Lurvey, Note, Who is Bespeaking to Whom? Plaintiff Sophistication, Market Information, and Forward-Looking Statements, 45 Duke L J 579, 587 \& n 46 (1995).

${ }^{93}$ Section 27A(i)(1) provides a definition of "forward-looking statement" that includes statements containing financial projections, the plans and objectives of management, and the management's discussion and analysis of the company's financial condition or results of operations. See Section 27A(i)(1), Securities Act, codified at 15 USCA § 77z-2(a)(i)(1). Section 27A does make several exclusions based on past bad acts, specific transactionsincluding going private transactions, tender offers, and initial public offerings, among other exclusions. See Section 27A(b), Securities Act, codified at 15 USCA § 77z-2(b).

* See Rule 175(b)(1), Securities Act, 17 CFR § 230.175(b)(1) (1996).

${ }^{9}$ See Rule 175(a), Securities Act, 17 CFR § 230.175(a) (1996).

${ }^{96}$ See Section 27A(c)(1), Securities Act. The meaningful cautionary statements must accompany the forward-looking statement. Furthermore, the forward-looking statement must be specifically identified as such. See Section $27 \mathrm{~A}(\mathrm{c})(1)(\mathrm{A})$, Securities Act, codified at 15 USCA § 77z-2(c)(1)(A). Furthermore, the plaintiff bears the burden of proof of demonstrating that the defendant (or an executive officer where the issuer is the defendant) had actual knowledge. See Section 27A(c)(1)(B), Securities Act, codified at 15 USCA § 77z2(c)(1)(B). 
applies only to Exchange Act reporting companies and their agents $;^{97}$ even initial public offering issuers, conversely, may take advantage of Rule 175 to protect forward-looking statements made in the registration statement. ${ }^{98}$ The current forwardlooking information safe harbors, therefore, do take a somewhat status-based approach, recognizing at least partially that the danger of fraudulent forward-looking statements misleading investors varies with the company involved.

This Article contends that lawmakers should more explicitly take into account differences among companies in constructing information safe harbors. As an initial matter, lawmakers may wish to focus on three facets of the information safe harbors: (a) the medium of the forward-looking statement-whether oral or written, and if written, what type of document; (b) the information investors are required to receive or possess in addition to the forward-looking statement; and (c) the state of mind required of the issuers. For companies that trade in an efficient market with a large analyst following, the danger of misleading forwardlooking statements is at a minimum while the risk of frivolous litigation is large. Institutional investors of larger, well followed issuers, for example, have both a larger amount of information and greater resources to analyze a company's forward-looking disclosures. ${ }^{99}$ Moreover, less sophisticated investors of large issuers are protected through the secondary market price mechanism in an efficient market. Associated certification intermediaries will also be more willing to put their reputation for screening against fraud on the line and invest resources into assessing the issuer. For such companies, a safe harbor should exist for forward-looking information disclosures without restriction on the means of transmission-oral or written-because investors will assess the forward-looking statement equally well regardless of the medium. Furthermore, because information exists in the market to protect investors through an efficient price mecha-

${ }^{57}$ See Section 27A(a), Securities Act, codified at 15 USCA § 77z-2(a). In addition to the issuer, persons acting on behalf of the issuer, outside reviewers retained by the issuer, and underwriters may make use of Section 27A. See id. Moreover, forward-looking statements made in connection with an initial public offering are expressly excluded from the safe harbor. See Section 27A(b)(2)(D), Securities Act, codified at 15 USCA \& 77z2(b)(2)(D).

${ }^{*}$ See Rule 175(b)(1)(ii), Securities Act, 17 CFR § 230.175(b)(1)(i) (1996). In addition, persons acting on behalf of the issuer and an outside reviewer retained by the issuer may make use of the safe harbor. See Rule 175(a), 17 CFR § 230.175(a) (1996).

${ }^{9}$ See Wielgos $v$ Commonwealth Edison Co, 892 F2d 509, 517 (7th Cir 1989) ("Issuers of securities must reveal firm-specific information. Investors combine this with public information to derive estimates about the securities' value. It is pointless and costly to compel firms to reprint information already in the public domain."). 
nism, so long as the market as a whole has enough information to correctly assess the disclosure, no further information should be required of the issuer. Issuers, in other words, should face a duty only to disclose firm-specific information that is necessary for the market to interpret intelligibly the forward-looking statements and that the market does not already possess. ${ }^{100} \mathrm{Al}$ though meaningful cautionary statements made together with a forward-looking statement may satisfy this requirement, where the information already exists in the market, cautionary statements should not be required of well followed companies. Finally, because of the fear of frivolous suits, larger, well followed companies should be allowed to use a forward-looking statement safe harbor even where the market lacks adequate information on the projections so long as the plaintiff fails to demonstrate actual knowledge on the issuer's part.

Conversely, the risk of misleading information for smaller, lightly followed companies is greater while the danger of frivolous suits is reduced. For such companies, therefore, it may first make sense to restrict the forward-looking statement safe harbor to documents that the SEC may have some chance to review. For example, Rule 175 restricts its safe harbor protections to only certain Exchange Act filings and the registration statement under the Securities Act. ${ }^{101}$ Second, because the market most likely is not efficient for small, less well followed companies, simply relying on publicly available information to provide investors a sufficient basis with which to interpret the issuer's projections may prove inadequate. Therefore, smaller companies should face a requirement that meaningful cautionary language specifically tailored to provide investors enough basis to decipher the projections intelligibly be delivered with the forward-looking statements. Third, because the danger of frivolous suit is less, issuers seeking to make use of a forward-looking information safe harbor should also - in addition to the meaningful cautionary language requirement-be required to demonstrate that they acted in good faith.

To put these insights into the current Form S-1, S-2, S-3 framework, this Article proposes the following forward-looking information safe harbor regime. S-3 companies-possessing the greatest presumption of market efficiency and alternative anti-

\footnotetext{
${ }^{100}$ In other words, there must exist a reasonable basis in the market to interpret the projection. See id at 516 (holding that for purposes of Rule 175 a reasonable basis exists so long as no firm-specific information necessary to interpret the forward-looking statements is absent from the market).

${ }^{101}$ See Rule 175(b)(1), Securities Act, 17 CFR $\S 230.175(b)(1)$ (1996).
} 
fraud mechanisms-should be allowed to make forward-looking disclosures freely as under Section 27A with one significant change: rather than being required to deliver meaningful cautionary language with the forward-looking statement, issuers should be allowed to demonstrate either that they supplied such cautionary language or else that the market already possessed enough information to assess the projections (the "broad scope" safe harbor).$^{102}$ At the other extreme, S-1 companies should be restricted to the current regime's Rule 175 safe harbor with one difference: rather than a reasonable basis, S-1 companies should be required to demonstrate that they delivered meaningful cautionary language directly to investors (the "restricted scope" safe harbor). Finally, an S-2 company should be allowed to use a forward-looking information safe harbor for (a) forward-looking statements in all forms of oral and written communications; (b) so long as the company provided meaningful cautionary language or the market had enough information to form a reasonable basis; and (c) the S-2 company also acted in good faith (the "intermediate scope" safe harbor).

\section{Scienter.}

Scienter represents one of the greatest barriers to securities fraud actions. Where no scienter is required, as under Section 11, plaintiffs have a relatively easy time proving other aspects of the cause of action that depend on more objective elements. The chances of success at trial diminish with Section 12(a)(2), which may require plaintiffs to rebut the defense that the defendants did not have knowledge or with reasonable care could not have obtained knowledge of the misstatement or omission. Finally, plaintiffs face the greatest hurdle proving actual intent or recklessness under Rule 10b-5.

Although the differences in the antifraud liability system's use of scienter now vary by transaction, the availability of the alternative antifraud mechanisms, as well as the risk of frivolous litigation, counsel for varying the scienter requirement based on the company's status. For example, one possible system would assign S-3 companies antifraud liability based on actual intent or recklessness regardless of the transaction in which they engaged. S-2 companies would face liability to the extent they acted without reasonable care in their disclosures. Finally, strict liability would apply to S-1 companies. Such a system would provide the

${ }^{102}$ See Wielgos, 892 F2d at 516. 
greatest amount of legal antifraud liability where market-based mechanisms are at their weakest: for S-1 companies. ${ }^{103}$

\section{Third-party liability.}

The final antifraud element that should vary based on company status is the extent of liability on third parties associated with the company. ${ }^{104}$ For all types of issuers, third parties play a crucial role in signaling the value and quality of the offering to the public. The market, moreover, provides third parties acting as gatekeepers with an incentive to maintain their vigilance. Underwriters, for instance, are paid by issuers based on their ability to attract investors; underwriters, in turn, attract investors through the underwriters' reputation for screening lowquality issues. Legal liability on third parties acts as a secondary incentive mechanism to ensure that third parties truly act as gatekeepers. As with legal liability on issuers, however, legal liability on third parties is not cost-free. Gatekeepers may respond to legal liability through excessive screening expenditures or, alternatively, third parties may simply refuse to participate in the offering transaction. This cost increases with the greater probability of frivolous litigation, as in the case of the larger companies. Moreover, as discussed above, the market-based incentive of third parties to act as gatekeepers is strongest for larger, more capitalized companies and companies with larger offerings. ${ }^{105}$

\footnotetext{
${ }^{103}$ Moreover, for companies with relatively less leeway to engage in fraud-for example where a number of analysts follow the company, managers face reputational pressures to remain truthful, and certifiers possess strong market-based incentives to screen for fraud-requiring a greater showing of scienter provides two direct benefits. First, the possibility of frivolous suits is reduced to the extent scienter becomes another issue on which securities defendants may rid themselves of a suit under summary judgment. Second, with a greater scienter requirement, antifraud liability acts to discipline only the most egregious fraudulent statements or omissions, leaving the market to deter less open instances of fraud. See text accompanying notes $66-68$ for a discussion of the marketbased incentive for third-party intermediaries to screen for fraud.

${ }^{10}$ The present Section 11 and Section 12(a)(2) liability provisions provide different scopes of third-party liability. Section 11 imposes liability on officers and directors of the issuer, underwriters, and experts including auditors. See Section 11(a), Securities Act, codified at 15 USC $\S 77(\mathrm{k})(\mathrm{a})$. Section 12(a)(2), conversely, imposes liability on those third parties that acted to solicit an offer to buy from the investor. Therefore, brokers that would not be considered underwriters under Section 2(11) and, as a result, not within Section 11 liability may still face Section 12(a)(2) liability. Similarly, auditors that are targeted specifically for Section 11 liability may escape Section 12(a)(2) liability to the extent they never deal directly with the investors. See Section 12(a)(2), Securities Act, codified at 15 USCA $\$ 771(a)(2)$. A detailed examination of the optimal range of third-party liability is outside the scope of this Article. Rather, at a minimum, the Article assumes that third-party liability, where it is justified at all, should fall on major participants in an offering-including the underwriters, auditors, and officers and directors of the issuer.

${ }^{105}$ See text accompanying notes 69-72.
} 
As a starting point, this Article proposes the following thirdparty liability scheme. First, the scope of third-party liability should fall only on a clearly defined set of third parties that operate under a market relationship with the issuer. Section 11 provides such a well defined list of possible third-party defendants, imposing liability on underwriters, experts with respect to expertised portions of the registration statement, and directors and key officers of the issuer. Neither Section 12(a)(2) nor Rule 10b-5, however, currently provides a similarly well-defined scope of third-party liability. ${ }^{106} \mathrm{Ex}$ ante clarity is important to provide those third parties who are able to screen for fraud the incentive to do so and relieve other third parties from the fear of liability. Moreover, under all three liability provisions, those third parties with the ability to screen for fraud and signal this information to the market remain the same. The scope of third-party liability, therefore, should also remain constant-focusing on underwriters, experts (for example, accountants with respect to information in the financial statements), directors, and officers.

Second, the level of third-party liability should vary based on whether the issuer is an S-1, S-2, or S-3 company. To achieve the full benefits of a market-based certification, third-party intermediaries associated with S-3 companies should face no legal liability. Likewise, because of the danger that certifiers associated with S-1 companies may have fewer market-based incentives to screen faithfully for fraud-and the certification market may collapse as a result for such companies-third-party liability should be placed on certifiers, with a due diligence defense for third parties that perform a reasonable investigation and have a reasonable and actual belief in the accuracy of the issuer's disclosures. Through the due diligence defense, third parties are given an incentive to maintain a standard of screening at least as great as required by due diligence. Finally, third parties associated with S-2 companies should face the same standard of investigation and care required of third parties associated with S-1 companies; however, to account for the greater danger of frivolous suits, the burden should be on plaintiffs to prove that third parties failed to meet this standard of investigation and care and acted negligently.

Table 1 summarizes the proposed status-based level of antifraud liability that different companies should face regardless of the type of primary transaction in which they engage. The remainder of this Article refers to the three levels of liability as

${ }^{106}$ See text accompanying notes $84-87$. 
Level I for S-1 companies, Level II for S-2 companies, and Level III for S-3 companies.

Table 1: Elements of Status-Based Antifraud Liability

\begin{tabular}{|c|c|c|c|}
\hline & \begin{tabular}{|l} 
Level I \\
(Form S-1)
\end{tabular} & \begin{tabular}{|l} 
Level II \\
(Form S-2)
\end{tabular} & \begin{tabular}{|l}
$\begin{array}{l}\text { Level III } \\
\text { (Form S-3) }\end{array}$ \\
\end{tabular} \\
\hline \begin{tabular}{|l} 
Scienter / \\
Standard of \\
Care \\
\end{tabular} & - Strict Liability & - Negligence & - Scienter \\
\hline \begin{tabular}{|l} 
Third-Party \\
Liability
\end{tabular} & \begin{tabular}{|l} 
Experts, \\
Underwriters, \\
Officers \& \\
Directors \\
\\
- Reasonable \\
Investigation, \\
Reasonable \\
Belief Defense \\
\end{tabular} & $\begin{array}{l}\text { Experts, } \\
\text { Underwriters, } \\
\text { Officers \& } \\
\text { Directors }\end{array}$ & $\begin{array}{l}\text { None (issuer } \\
\text { only is liable) }\end{array}$ \\
\hline $\begin{array}{l}\text { Forward- } \\
\text { Looking } \\
\text { Statements } \\
\text { (Scope of } \\
\text { Materiality) }\end{array}$ & $\begin{array}{l}\text { Good Faith and } \\
\text { Accompanying } \\
\text { Meaningful } \\
\text { Cautionary } \\
\text { Language } \\
\\
\text { - SEC Filing } \\
\text { Documents } \\
\text { only } \\
\end{array}$ & $\begin{array}{l}\text { - Good Faith and } \\
\text { Reasonable } \\
\text { Basis within } \\
\text { the Market } \\
\\
\text { - Any Document } \\
\text { or Oral } \\
\text { Disclosure } \\
\end{array}$ & $\begin{array}{l}\text { Good Faith or } \\
\text { Reasonable } \\
\text { Basis within } \\
\text { the Market } \\
\text { Any Document } \\
\text { or Oral } \\
\text { Disclosure }\end{array}$ \\
\hline
\end{tabular}

D. Refining Status-Based Antifraud Liability

Several possible arguments exist against a shift toward status-based antifraud liability. First, some commentators may view a status-based antifraud system as unfairly penalizing S-1 companies. The proposed status-based approach seems in conflict with the trend within both the SEC and Congress to facilitate raising capital for smaller-sized firms. Both the SEC and Congress, in fact, have repeatedly adopted initiatives to reduce the cost of issuing securities for small companies. Small businesses, for example, may use either Regulation A or Rule 504 of Regulation $\mathrm{D}$ to issue moderate amounts of nonrestricted securities into the general marketplace without undergoing Section 5's public 
offering process. ${ }^{107}$ Such issues, furthermore, are immune from Section 11 or 12(a)(2) liability and face only Rule 10b-5's level of antifraud deterrence. Although investors may have relatively less public information on these small issuers, the desire to reduce the cost of raising capital for small businesses may justify such exemptions. Placing a more stringent level of antifraud liability on these small issuers, therefore, runs counter to the goal of increasing the access small businesses have to the capital markets.

On the other hand, the danger of frivolous or even meritbased litigation for small issuers is not great. ${ }^{108}$ Therefore, imposing a higher level of antifraud liability may not impose too large a cost on issuers to the extent most small issuers will never experience an antifraud suit in any case. Although antifraud liability may increase, on an absolute level, even if some antifraud suits are frivolous, the probability of such suits is small. Furthermore, to the extent market-based antifraud mechanisms are weak for small issuers, raising the level of legal antifraud liability may have a relatively large deterrent effect. Moreover, to the extent small companies do pose a greater risk of fraud, failing to raise the level of antifraud liability provides such companies with too great a benefit. If the government wishes to encourage such companies, more direct subsidies-such as tax breaks-make more sense from the standpoint of protecting the integrity of the capital markets.

Second, others may claim that imposing Section 11-type liability on S-1 companies for all forms of primary transactions in which the S-1 companies engage will have negative consequences on the disclosure of even truthful information from such companies. This argument, however, depends critically on the assump-

\footnotetext{
${ }^{102}$ See, for example, Linda C. Quinn, Reforming the Securities Act of 1933: A Conceptual Framework, Insights 25, 27 (Jan 1996) ('From the investors' perspective, the increased compensation to distributors and the compressed period of the selling effort, as well as the issuer's interest in obtaining funds, set up a situation in which potential conflicts of interest between investors and sellers are enhanced.").

Quinn also argues that primary market transactions should take on more importance because fraud within such transactions directly impacts capital allocation decisions in the economy, whereas secondary market transactions do not. Id at 27. Secondary market disclosures, however, may indirectly affect primary transactions. For example, issuers often look to the secondary market price in determining whether to conduct an offering and at what price. Furthermore, other companies may base both their internal capital allocation and external financing decisions on their own and other companies' secondary market prices.

${ }^{100}$ This is true at least to the extent small companies tend to raise only small amounts of capital. See Bohn and Choi, $144 \mathrm{U}$ Pa L Rev at 936 (cited in note 35) (noting that initial public offerings with offering amounts below $\$ 1.79$ million almost never faced a securities fraud class action in connection with the offering).
} 
tion that some amount of error takes place either at trial or at settlement in a securities fraud suit. For example, to the extent issuers are willing to settle even frivolous complaints, then issuers may find truthful information disclosure costly. Without error or frivolous suits, conversely, issuers face no antifraud liability from engaging in truthful disclosures. ${ }^{109}$ Furthermore, frivolous suits may occur regardless of the level of even truthful information disclosure. Such suits, for example, may be brought based on an alleged omission of material information; so long as a duty to disclose is present, ${ }^{110}$ no explicit information disclosure of any type is required in alleging a fraud suit. Evidence exists, in fact, that the type of information disclosure alleged fraudulent in a securities class action suit has little impact on the relationship between the eventual settlement and the potential damage award in such a suit. ${ }^{111}$ Additionally, even if error is present at trial, reducing the substantive level of antifraud liability may not be the best way of addressing this problem. After all, antifraud liability also works to deter truly fraudulent disclosures or omissions; reducing liability, therefore, may increase the incidence of actual fraud in addition to truthful information disclosures. The procedural screens imposed through the Private Securities Litigation Reform Act, therefore, may provide a better means of reducing the incidence of frivolous suits, at least for less well followed companies.

Third, some may also argue that larger, more well followed companies may gain the most from fraudulent disclosures or omissions and, moreover, may share this with their third-party intermediaries as an inducement to certify fraud. Investors, holding the belief that fraud is less likely for such companies and their certifiers, will discount less for fraud and therefore provide an appetizing target for fraudulent issuers. However, it seems doubtful that investors would systematically hold incorrect beliefs as to the incentives of large, well followed companies and their intermediaries. Investors that correctly anticipate the incentive of issuers and their intermediaries to engage in fraud on average will discount the shares of such companies, reducing the gain from fraud for such companies in turn. In fact, two equilibria are possible: (a) certifiers may remain unable to bond

\footnotetext{
${ }^{100}$ See Arlen and Carney, $1992 \mathrm{U}$ II L Rev at 692 n 8 (cited in note 55).

${ }^{110}$ The Management's Discussion and Analysis section of the registration statement, for example, provides a duty to disclose a variety of information on the current operations and financial condition of the issuer. See Item 303, Regulation S-K, Securities Act, 17 CFR § 229.303 (1996).

${ }^{11}$ See Bohn and Choi, 144 U Pa L Rev at 970-76 (cited in note 35).
} 
themselves to faithfully executing their certification role, and investors will treat the certification as worthless and discount accordingly. In this case, even well followed companies will have no particular ability to defraud investors on average. Or (b) certifiers may find some means of bonding themselves to screening for fraud - either through legal liability or market reputation-and therefore investors will believe that on average company disclosures-at least after certification-are relatively truthful. In this equilibrium, however, certifiers must maintain their accurate screening and stop issuers from engaging in fraud in order to maintain their reputations. Therefore, in the second possible equilibrium, large, well followed issuers also possess no special ability to defraud investors.

Finally, the incentive of companies to engage in misleading disclosures may in fact vary based on the type of primary transaction involved. ${ }^{112}$ As a result, the need of investors for antifraud protections may also vary across different transactions, counseling against a status-based antifraud regime.

Public offerings typically are sold to a wide range of investors, including individuals. Accordingly, public offering investors

${ }^{12}$ Although this Article does not focus on the question of antifraud liability for secondary market transactions, arguably even for information disclosures outside the context of a primary issuance of securities the level of liability on the company should vary based on the status of the company. Some may argue, however, that companies engaged in a public offering possess a greater incentive to mislead; overstating earnings and other financial information, for example, may directly raise an issuer's offering proceeds. See, for example, Quinn, Insights at 27 (cited in note 107) ("From the investors' perspective, the increased compensation to distributors and the compressed period of the selling effort, as well as the issuer's interest in obtaining funds, set up a situation in which potential conflicts of interest between investors and sellers are enhanced."). In contrast, companies without an ongoing public offering may have less incentive to produce misleading information that may act only to affect secondary market prices. This argument lacks force, however, because secondary market prices do matter to companies and their managers. Managers, for example, care greatly about secondary market prices to the extent they may engage in secondary market trades for their own account or possess options in the company's stock. More importantly, the secondary market price often directly determines the ability of companies to conduct a seasoned offering at a particular price. See note 107 (describing the link between secondary market and offering prices). Therefore, the distinction between information that affects the company's offering price and information that only affects the secondary market price is ambiguous at best.

Nevertheless, unlike in a primary market transaction, it is unclear at what level the amount of damages should be set for fraud in secondary market transactions. See Donald C. Langevoort, Symposium, Capping Damages for Open-Market Securities Fraud, 38 Ariz $\mathrm{L}$ Rev 639, 642-43 (1996) (arguing that damages in fraud on the market cases should be aimed at deterring violators, rather than compensating victims); Frank Easterbrook and Daniel Fischel, Optimal Damages in Securities Cases, 52 U Chi L Rev 611, 612-14 (1985) (applying an economic model to determine the optimal level of damages). Therefore, although the same standards of liability should apply between primary and secondary market information disclosures, additional analysis beyond the scope of this Article is required to determine the correct damages level. 
may differ considerably in their investment expertise. Private placements, on the other hand, are sold mostly to institutional investors and others with either a great degree of investment sophistication (or access to such sophistication through their investment advisors) or insider access to the issuer. ${ }^{113}$ Such investors may neither require nor value high levels of antifraud liability. If this characterization is true, social welfare increases with higher levels of antifraud liability for public offerings relative to private placements.

But private placements may also include investors without great investment sophistication. Under Rule 504 of Regulation D, for example, issuers may sell securities to any number of investors, regardless of their sophistication, so long as they keep the total offering amount below $\$ 1$ million. ${ }^{114}$ Regulation $D$ also allows issuers to sell securities under Rules 505 or 506 to as many accredited investors as they desire. ${ }^{115}$ Although accredited investors do include institutional investors and other seemingly sophisticated investors, the reach of the definition is overly broad; it includes all individual investors making more than $\$ 200,000$ per year or worth over $\$ 1$ million regardless of their financial expertise. ${ }^{116}$ Indeed, both Rules 505 and 506 allow the sales of securities to up to thirty-five unaccredited investors. ${ }^{117}$ Whether private placement investors systematically possess a greater degree of sophistication over public offerings is therefore debatable. Furthermore, other exempt transactions, including intrastate offerings, ${ }^{118}$ possess a range of investors little different from a general public offering.

Even were private placements to contain a significantly different pool of investors from public offerings, the argument for a different level of antifraud liability is still suspect. For example, although investors may be more sophisticated in a private placement, the presence of sophisticated investors in an S-3 company's public offering will protect unsophisticated investors. Although not all investors in a public offering may receive the prospectus before they make their purchase decision, at least some of the more sophisticated investors will receive this information.

\footnotetext{
${ }^{123}$ See Section 4(1), Securities Act, codified at 15 USC § 77d(2).

${ }^{114}$ See Rule 504, Regulation D, Securities Act, 17 CFR § 230.504 (1996).

${ }^{115}$ See Rules 505 and 506, Regulation D, Securities Act, 17 CFR § 230.505-06 (1996).

${ }^{116}$ See Rule 501(a), Regulation D, Securities Act, 17 CFR \& 230.501(a)(5)-(6)(1996).

${ }^{117}$ See Rules 505 and 506, Regulation D, Securities Act, 17 CFR $\S$ 230.505(b)(2)(ii), $230.506(\mathrm{~b})(2)(\mathrm{i})$.

${ }^{118}$ See Section 3(a)(11), Securities Act, codified at 15 USC \$ 77c(a)(11) (exempting intrastate offerings); Rule 147, Securities Act, 17 CFR $\$ 230.147$ (1996) (clarifying transactions covered and defining terms used in the Section 3(a)(11) exemption).
} 
Sophisticated investors may also look to the SEC filings pursuant to the offering to obtain information on the offering. These investors will then trade in the secondary market until all information from the offering is incorporated into the secondary market price. Issuers will then set their offering price based on this secondary market price; to do otherwise would either run the risk of driving away investors, to the extent the secondary market price is lower than the offering price, or giving up offering proceeds, where the secondary market price is greater than the offering price. Unsophisticated investors in a public offering of S-3 company securities, therefore, are protected through the secondary price mechanism. For S-3 companies, the different pools of investors simply do not matter.

Now take the case of an S-1 company contemplating both a public and private offering. Here the opponents of the statusbased liability regime can make their best argument for some tailoring of antifraud liability based on the type of investors involved in the transactions. Unlike S-3 offerings, regulators may not presume the existence of an efficient market mechanism to transmit information from one type of offering to the other. Similarly, the number of sophisticated investors may be limited. Furthermore, no secondary market price signal may exist to transmit the information known to sophisticated investors to other investors.

Regulators, as a result, may wish to add a transaction-based component to the basic status-based antifraud approach detailed in this Article. This Article therefore proposes a possible refinement to the status-based regime outlined above: Antifraud liability for S-1 companies in the private placement context should decrease modestly from Level I liability to Level II liability. S-1 companies would still face Level I liability for public offerings.

Nonetheless, it is important not to overstate the importance of the transaction-based aspect of antifraud liability. Although some investors may be more sophisticated in private placements for S-1 companies, even these sophisticated investors may not make the necessary fixed cost expenditures to assess fully the companies' true value to the extent the market capitalization and offerings from S-1 companies tend to be smaller. ${ }^{119}$ Furthermore, the alternative antifraud mechanisms are at their weakest for $\mathrm{S}$ -

\footnotetext{
${ }^{119}$ Of course, investors in a private placement may individually obtain a larger share of the private placement than they would in a public offering. Even if they were to do so, investors would still have more incentive to invest in assessing the value of a public offering to the extent the resulting trading market allowed them to take advantage of any information they learned (for example, through short sales).
} 
1 companies. ${ }^{120}$ Even within a private placement involving more sophisticated investors, investors must take into account that the S-1 company has a lower analyst following, a reduced managerial reputational incentive to avoid fraud, and potentially absent or lower-quality third-party certification intermediaries.

\section{STATUS-BASED REGISTRATION AND DISClOSURE}

Despite the arguments for status-based antifraud liability, most commentators have instead focused on introducing statusbased registration and disclosure requirements more formally into the securities laws. Under the rubric of "company registration," the SEC's Advisory Committee Report represents the culmination of recent academic and governmental efforts toward implementing status-based registration and disclosure. This Part analyzes the transaction- versus status-based approaches within the current regime and discusses the Advisory Committee's proposed reforms. The Article concludes that the reforms do little to move current practices substantively further toward a company registration system. Most of the proposed reforms do not deal directly with company registration, but instead involve incremental adjustments in the current regime. To the extent the Advisory Committee's reforms actually do make a substantive impact on registration and disclosure practices, the Article argues that a status-based antifraud regime accomplishes the same results with lower transaction and uncertainty costs.

\section{A. The Current Regime}

The current regime's dual status- and transaction-based approaches stem from the initial separation of functions between the Securities Act and Exchange Act. Conceived as a means to protect investors from the "sharp" practices of issuers, the Securities Act regulates individual securities market transactions. ${ }^{121}$ To guard against the incentive of issuers to mislead during an offering and to ensure that investors receive adequate investment information, the Securities Act's transaction approach provides investors and the SEC a convenient focal point for regulation. Especially where information on particular companies is not readily available, targeting issuer-initiated transactions allows

\footnotetext{
${ }^{120}$ See Section I.B.

${ }^{221}$ Section 5 of the Securities Act serves as the linchpin for this transaction-based focus. Section 5(a), Securities Act, codified at 15 USC $\S 77$ (a), makes unlawful any sale of a security through the means of interstate commerce, unless the security is sold under an effective registration statement.
} 
the SEC to provide information where investors most need protection. The Exchange Act, in contrast, focuses more on protecting the secondary markets and ensuring their integrity. ${ }^{122}$ Many secondary market transactions do not directly involve the issuer, but rather take place with market participants on both sides of transactions. Waiting for an issuer-initiated transaction to trigger information disclosure may leave these market participants without adequate investment information. To provide all secondary market investors with timely information, the Exchange Act takes a status-based approach, forcing issuers meeting certain requirements to file periodic information updates with the SEC, which are subsequently transmitted to the market. ${ }^{123}$ This Section (1) details the transaction focus within the Securities Act, and (2) compares it to the Exchange Act's statusbased approach. ${ }^{124}$

\section{Securities Act.}

The linchpin of the Securities Act's transaction focus is the registration process of Section 5 of the Act. Commonly referred to as the gun-jumping rules, the registration process carefully controls the flow of information to investors and proceeds through three distinct phases. In the "pre-filing period," Section 5(c) restricts all offers and sales prior to the filing of the registration statement with the SEC. ${ }^{125}$ After the registration statement is

\footnotetext{
${ }^{122}$ The Exchange Act includes a smorgasbord of provisions aimed at regulating exchanges and the National Market System, brokers and dealers, insider short-swing profit trading, and market manipulation. See, for example, Section 9, Exchange Act, codified at 15 USC § 78i (prohibiting manipulation of security prices). This Article focuses solely on the Exchange Act's disclosure and antifraud provisions.

${ }^{223}$ The periodic disclosure filings are public documents. Furthermore, under the SEC's Electronic Data Gathering Analysis and Retrieval System ("EDGAR"), investment analysts may easily access this information through a computer link to the SEC or other archival sources. See Regulation S-T, Exchange Act, 17 CFR $\S \S 232.10$ et seq (providing general rules and regulations for electronic filings). See also Bloomenthal and Holme, Roberts \& Owen, Securities Law Handbook $\$ \S 13.01-13.10$ (cited in note 27) (providing an overview of the EDGAR system).

${ }^{12 x}$ Transactions occurring under Section 5 are also subject to the more stringent antifraud provisions of Sections 11 and 12(a)(2) of the Securities Act; moreover, any technical violations of Section 5 make the seller liable for recission under Section 12(a)(1) of the Securities Act. See Section 12(a)(1), Securities Act, codified at 15 USC § 771(a)(1).

${ }^{225}$ Section 5(c), Securities Act, codified at 15 USC § 77e(c). Offers, furthermore, are construed broadly, greatly limiting the ability of issuers and their associates to release information relating to the offering. See Section 2(3), Securities Act, codified at 15 USC $\S$ $77 \mathrm{~b}(3)$; Publication of Information Prior to or After the Filing and Effective Date of a Registration Statement Under the Securities Act, SEC Securities Act Release No 5009, 1 Fed Sec L Rptr (CCH) II 1465 (Oct 7, 1969); Publication of Information Prior to or After Effective Date of Registration Statement, SEC Securities Act Release No 3844, 1 Fed Sec L Rptr (CCH) III 3250-56 (Oct 8, 1957).
} 
filed, but before it becomes effective (the "waiting period"), issuers and their associates may not make any sales; furthermore, written communications are allowed only in the form of a Section 10(b) preliminary prospectus. ${ }^{126}$ Finally, once the registration statement becomes effective, sales may commence and written material other than the statutory prospectus may be sent to potential investors, but only if a Section 10(a) statutory prospectus is sent either prior to or concurrently with the communication to investors (the "post-effective period"). ${ }^{127}$ Section 5 does not limit its reach solely to issuer-initiated transactions; rather, Section 5 sweeps broadly, regulating every offer and sale of a security. ${ }^{128}$ Under Section 5's terms, even secondary market transactions between two individual investors must satisfy the registration process or else qualify for an available exemption within the Securities Act. ${ }^{129}$ The effectiveness of a registration statement, however, lapses after a certain period of time. ${ }^{130}$ Accordingly, resellers in the secondary market cannot rely on the registration statement under which the securities were initially sold to satisfy Section 5(a).

Through a series of broad exemptions for most secondary market transactions, however, the Securities Act confines its operation primarily to the offering of securities in the securities market by an issuer or a control person of the issuer. ${ }^{131}$ The vast majority of secondary market transactions are exempted from Section 5 through Section 4(1), which places all transactions not involving an issuer, underwriter, or dealer outside the reach of Section 5. ${ }^{132}$ Although the definition of underwriter is broad, ${ }^{133}$

\footnotetext{
${ }^{120}$ See Section 5(b)(1), Securities Act, codified at 15 USC $\$ 77 \mathrm{e}(\mathrm{b})(1)$ (prohibiting transmission of non-10(b) prospectus); Section 2(10), Securities Act, codified at 15 USC § $77 \mathrm{~b}(10)$ (defining "prospectus").

${ }^{127}$ See Section 5(b)(2), Securities Act, codified at 15 USC $\$ 77 e(b)(2)$ (prohibiting sale of security without accompanying or preceding 10(b) prospectus); Section 2(10), Securities Act, codified at 15 USC $\$ 77 \mathrm{~b}(10)$ (defining "prospectus").

${ }^{123}$ Section 2(3) of the Securities Act, codified at 15 USC $\S 77 \mathrm{~b}(3)$, broadly defines an "offer" of a security to include solicitations of offers. 5).

${ }^{129}$ See text accompanying notes $144-49$ (describing the different exemptions to Section

${ }^{130}$ See Section 6(a), Securities Act, codified at 15 USC § 77f(a) ("A registration statement shall be deemed effective only as to the securities specified therein as proposed to be offered."). Almost from the start, the SEC has viewed Section 6(a) as mandating that the registration of securities other than those the issuer intended to offer in the near future is misleading. See In re Shawnee Chiles Syndicate, 10 SEC 109, 113 (1941).

${ }^{131}$ Those that assist a control person in selling her securities are considered underwriters. See Section 2(11), Securities Act, codified at 15 USC \& 77b(11).

${ }^{132}$ See Section 4(1), Securities Act, codified at 15 USC § 77d(1) (exempting transactions "by any person other than an issuer, underwriter, or dealer"). See also Section 4(3)(4), Securities Act, codified at 15 USC § 77d(3)-(4) (exempting certain dealer transactions and unsolicited broker transactions).
} 
most secondary market transactions of registered securities do not involve such an underwriter, and therefore may rely on the Section 4(1) exemption. ${ }^{134}$

The complex machinery of the Securities Act manifests itself primarily in three areas, each regulating the path that securities may travel from an issuer or control person of the issuer to the general securities marketplace. These three areas broadly cover public offerings, nonpublic offerings, and resales of restricted securities. For each area, problems caused by the Securities Act transaction-based approach are discussed below.

a) Public offerings. The starkest contrast between the current transaction-focused system under the Securities Act and a potential company registration regime is in the treatment of securities of the same company and class that happen to enter the market at different times and in a different manner. Take Realco, a company seeking to raise capital through sales of securities in the public capital markets. Realco may register one million shares of common stock with the SEC and sell these securities through a public offering. A secondary market may then develop and each subsequent secondary market seller may conduct transactions, without regard to the Securities Act's registration requirements, through Section 4(1)'s exemption. ${ }^{135}$ After its public offering, however, Realco may not authorize additional equity shares for sale to the general market without separately registering these securities. Even where Realco authorizes shares of the same class of common stock, because of the transaction focus within Section 5, Realco must register the new shares sepa-

${ }^{250}$ Section 2(11) of the Securities Act, codified at 15 USC $\$ 77(b)(11)$ defines the term "underwriter" to include not only all traditional institutions participating in a public offering, but also all purchasers who buy with a view toward resale, or who otherwise "participate" in the offering.

${ }^{13}$ More troublesome is the presence of a broker in almost all secondary market transactions. Section 2(12), codified at 15 USC § 77(b)(12), defines dealer to include the "agent, broker, or principal" in a securities transaction, excluding all transactions involving brokers at least literally from Section 4(1)'s exemption. But in combination with Section 4(3)'s nonparticipating dealers exemption, codified at 15 USC § 77(d)(3), and Section 4(4)'s unsolicited broker transaction exemption, codified at 15 USC \& 77(d)(4), courts have held that the mere presence of a broker does not disqualify a transaction from exemption under Section 4(1). See Ackerberg v Johnson, 892 F2d 1328, 1334 n 4 (8th Cir 1989) ("While it is true that $\S 4(1)$ exempts transactions and not individuals ... the mere involvement of a broker, qua broker, in a secondary transaction by persons other than an issuer, underwriter or dealer is insufficient to vitiate the exemption.").

${ }^{135}$ Note, however, that Realco may have to satisfy the periodic information disclosure requirements under Section 13 of the Exchange Act. See notes 6-7 (summarizing the periodic disclosure requirements). Nevertheless, most non-issuer secondary market parties need not provide any affirmative information. 
rately. ${ }^{136}$ The shares may possess the same voting, dividend, and liquidation rights; investors may value the shares the same, requiring similar information in calculating this value. From the investor's perspective, the shares are identical. Nevertheless, the trading status of individual units of a particular class of securities depends on the transaction-specific path that the securities take to investors. Where Realco's securities trade in an efficient market, however, it is unclear what is gained from treating securities differently that are in fact identical from the perspective of investors. Regardless of the path the securities take to the market, investors may rely on publicly available information common to the company in assessing the value of the securities. Conversely, where Realco's securities do not trade in an efficient market, then it is also unclear why the two different sets of Realco common stock should be treated differently. In both cases, relatively little public information will exist on the securities; investors transacting in either set of securities must make do with whatever information they individually hold.

At least for companies in an efficient market, one of the greatest advantages of a company registration system is its elimination of the need to register repeatedly securities of the same class. ${ }^{137}$ Because entire companies are registered, investors may freely purchase any security of the registered company; rather than becoming a focal point for regulation and disclosure, primary transactions simply are treated as any other major information event. Note, however, as this Article discusses below, as the cost of conducting repeated registrations of securities diminishes-through shelf offerings, for example ${ }^{138}$ - this advantage of formal company registration diminishes. Likewise, a true company registration system would similarly restrict the trading of securities of lightly followed companies with little public information regardless of the path the securities took to market. The Advisory Committee, however, does not examine this possibility, instead focusing exclusively on the implications of company registration for companies trading in an efficient market only.

The transaction focus of public offerings also manifests itself in the actual distribution of information during the offering. A

\footnotetext{
${ }^{236}$ See Section 6(a), Securities Act, codified at 15 USC $\S 77 \mathrm{f}(\mathrm{a})$ (" $\mathrm{A}$ registration statement shall be deemed effective only as to the securities specified therein as proposed to be offered.").

${ }^{27}$ See Cohen, 79 Harv L Rev at 1340-44 (cited in note 3) (illustrating varied results from similar situations under current disclosure system).

${ }^{138}$ See text accompanying note 262.
} 
specified set of information must be included in the statutory prospectus under Section $10(a){ }^{139}$ Section $5(b)(2)$, in turn, requires that the statutory prospectus accompany or precede the delivery of securities to purchasers. ${ }^{140}$ In a market where little is known about companies' securities and potential investors must individually determine the investment value of the securities, mandating information disclosure directly to potential investors has some merit. Without such disclosures, the investors may never learn or make use of company-specific information. Requiring the distribution of the prospectus to these individual investors, or to their investment advisors, may therefore reduce investors' overall cost of analyzing the offering's value. Note, however, that even for such lesser known companies, the interests of other stakeholders in the company are affected through the offering; nevertheless, only potential investors in the new securities are provided information. The transaction focus of the Securities Act's distribution of information fails to provide prior stakeholders with any information directly. Continuing with the Realco example, suppose Realco in fact trades in an inefficient market and little information is publicly available on Realco. Prior to Realco's first offering of common stock, assume that Realco sold $\$ 10$ million worth of bonds through another public offering also into a thinly traded and lightly followed market. The value of the bonds changes based on the offering of common stock: more equity raises the cushion of assets protecting bondholders in case of insolvency and thereby reduces the risk of default on the bonds, raising the bonds' value. The bondholders, however, do not receive the information disclosures related to the common stock offering under the current prospectus delivery requirement. ${ }^{141}$

Suppose alternatively that Realco is widely followed in an efficient market and financial analysts may easily obtain the information contained in the common stock offering prospectus either through brokers involved in the offering or directly from the SEC. For Realco investors, under these circumstances, it may not matter that the information on the offering is initially distributed only to the public offering purchasers and not to prior stakeholders; the efficient market will incorporate the information into secondary market prices. If Realco truly trades in an ef-

\footnotetext{
${ }^{129}$ See Section 10(a), Securities Act, codified at 15 USC $\$ 77 \mathrm{j}(\mathrm{a})$.

${ }^{100}$ See Section 5(b)(2), Securities Act, codified at 15 USC $\$ 77 e(b)(2)$.

${ }^{111}$ In this example, the value of the bonds increases. However, had the subsequent offering been of first mortgage bonds with senior priority, the value of the bonds might actually decline.
} 
ficient market, however, then even public offering purchasers do not require the information contained within the prospectus. Rather, so long as the information is distributed to investment professionals in some manner, the information will become incorporated in the secondary market price of the shares and thereby reflect itself in the offering price. ${ }^{142}$ In an efficient market, therefore, the distribution of information solely through a filing with a centralized, easily accessible information source, such as the SEC's Electronic Data Gathering Analysis and Retrieval System ("EDGAR"), ${ }^{143}$ may actually increase investor welfare, while lessening the cost to issuers of conducting a public offering.

b) Nonpublic offerings. In deciding to raise capital through the securities markets, issuers are not constrained to follow the public offering process dictated by Section 5 . The Securities Act furnishes several avenues to conduct either a nonpublic offering or a public offering of more limited scope. Under each exemption, the requirements imposed under the Securities Act focus primarily on the specific transaction involved. Although some of these transaction-specific requirements take into account the status of the issuer, they do so only within the confines of the particular transaction. Exemptions are provided for purely intrastate offerings, ${ }^{144}$ offerings essentially nonpublic in character under Section 4(2) of the Securities Act, ${ }^{145}$ Regulation D private placements, ${ }^{146}$ small-size offerings through Regulation $A,{ }^{147}$ and offshore transactions pursuant to Regulation S. ${ }^{148}$ For convenience of analysis, this Section focuses solely on private place-

\footnotetext{
${ }^{142}$ Of course, there is no requirement that the issuer peg its offering price to the secondary market price. Where the offering price is greater than the secondary market price for the same class of securities, however, investors will refuse to purchase the offering; similarly, where the offering price is below the secondary market price, the issuer may raise its offering proceeds simply by raising the offering price up to the secondary market price. The offering price will accordingly correlate closely with the secondary market price.

${ }^{233}$ Temporary Rules and Forms for the Pilot Electronic Disclosure System, SEC Securities Act Release No 6539, [1984 Transfer Binder] Fed Sec L Rptr (CCH) I 83,642 (June 27,1984 ) (SEC's temporary rules for EDGAR, adapting existing SEC rules to accommodate electronic filing); Electronic Filing, Processing and Information Dissemination System, SEC Securities Act Release No 6519, [1983-84 Transfer Binder] Fed Sec L Rptr (CCH) II 83,600 (Mar 22, 1984) (announcing introduction of EDGAR pilot program).

${ }^{14}$ Section 3(a)(11), Securities Act, codified at 15 USC § 77c(a)(11); Rule 147, Securities Act, 17 CFR $\$ 230: 147$ (1996).

${ }^{145}$ Section 4(2), Securities Act, codified at 15 USC \$ 77(d)(2).

${ }^{346}$ Rules 501-08, Regulation D, Securities Act, 17 CFR § 230.501-08 (1996).

${ }^{167}$ Rules 251-63, Regulation A, Securities Act, 17 CFR § 230.251-63 (1996).

${ }^{149}$ Rules 901-04, Regulation S, Securities Act, 17 CFR § 230.901-04 (1996).
} 
ments. The analysis, nevertheless, carries through to the other transaction exemptions. ${ }^{149}$

Rules 505 and 506 of Regulation D, for example, provide two alternate means of issuing securities in a nonpublic manner under Sections 3(b) and 4(2) of the Securities Act, respectively. Rule 505 requires that the total dollar amount of the offering not exceed five million dollars, and that the number of purchasers of the securities not exceed thirty-five. ${ }^{150}$ Rule 506, in contrast, sets no dollar limit on the offering; rather, Rule 506 limits the number of purchasers to thirty-five and requires that each purchaser meet a sophistication requirement. ${ }^{151}$ Under either exemption, certain highly qualified investors-deemed accredited investors under Rule 501-are not counted as "purchasers" and are not part of the thirty-five-investor limit. ${ }^{152}$

From the perspective of an individual transaction, Regulation D's safe harbors make some sense. In isolation, Regulation D ensures that those investors able to fend for themselves are given the opportunity to participate in a private offering without the high cost of compliance with Section 5's registration requirements. ${ }^{153}$ This transaction perspective, however, ignores that other investors besides participants in the private placement of-

\footnotetext{
${ }^{109}$ Although the other exemptions from Section 5 contain different prerequisites, they all take a transaction-based focus and, as a result, impose complex restrictions on resales. For example, issuers and control persons may seek to avoid the requirements of Section 5 through off-shore offerings of securities meeting the requirements of Regulation S. Under Regulation S, securities sold in an offshore transaction through a distribution not targeting the United States are exempt from Section 5's registration requirements. Rule 903, Regulation S, Securities Act, 17 CFR § 230.903 (1996). Even issuers incorporated in the United States may use Regulation $S$ to issue securities solely in France, for example, without any promotional effort in the United States, and thereby avoid Section 5's registration requirements. The transaction-based approach of Regulation $S$, however, imposes complex resale restrictions on these securities even though the U.S. issuer may have securities of the same class trading in the United States concurrently. See, for example, Stephen J. Choi and Andrew T. Guzman, The Dangerous Extraterritoriality of American Securities Law (forthcoming $\mathrm{Nw}$ J Intl L \& Bus) (describing how company registration may alleviate the flowback problem of Regulation S).

${ }^{250}$ Rule 505, Securities Act, 17 CFR \& 230.505 (1996).

${ }^{25 s}$ Rule 506, Securities Act, 17 CFR $\$ 230.506$ (1996). Rule 506 requires that "[e]ach purchaser who is not an accredited investor either alone or with his purchaser representative(s) has such knowledge and experience in financial and business matters that he is capable of evaluating the merits and risks of the prospective investment .... Rule 506(b)(2)(ii), Securities Act, 17 CFR \$ 230.506(b)(2)(ii) (1996).

${ }^{152}$ See Rule 501(a), Securities Act, 17 CFR § 230.501(a) (1996) (defining "accredited investor").

${ }^{153}$ Investors, for example, that are deemed "accredited" as defined under Rule 501(a)including individuals with a net worth of over $\$ 1$ million or an annual income of over $\$ 200,000$-may participate in a Rule 505 or 506 offering without counting toward the limit on the number of purchasers and without any mandatory information disclosure. See Rule 501(a), 501(e), Securities Act, 17 CFR § 230.501(a), (e) (1996).
} 
fering are affected by the offering. Other stakeholders in the issuer are affected by the change in capitalization from the private placement. Broadly speaking, even a private placement is an information event for all the stakeholders of the issuer. As with other significant events, the transaction affects the valuation of the issuer and is relevant to all investors. ${ }^{154}$ Although not important for companies that trade in an efficient market, this lack of information disclosure may be important for less followed companies and their prior stakeholders. ${ }^{155}$

c) Restricted resales. Securities sold through one of the exemptions from Section 5's registration requirements typically assume restricted status. As restricted securities, purchasers are unable to resell the securities to other investors without meeting another transaction exemption. Furthermore, Section 4(1)'s exemption for transactions not involving an issuer, underwriter, or dealer often is not available to these investors. The expansive definition of underwriter under Section 2(11) treats investors that purchase with a view to distribute as underwriters. ${ }^{156}$ Whether an investor has a view to distribute depends on the investor's motive at the time of purchase and the type of resale in which the investor engages. ${ }^{157}$ In practice, investors typically require at least a three-year holding period to obtain a presumption of investment motive and thereby escape classification as an underwriter directly under Section $2(11){ }^{158}$ To provide more cer-

\footnotetext{
${ }^{25}$ The transaction may affect the valuation of the issuer from the perspective of an individual investor in several different ways. First, the mere fact that the issuer is raising additional capital may signal that the issuer is about to engage in a project requiring such capital. Second, the choice of a private placement may also provide a signal about the issuer's intentions and attitude toward information disclosure to the public market. Finally, the creation of additional securities may affect the value of existing securities holders-particularly where the securities are of a different class and hold different voting, dividend, or liquidation rights. For example, holders of junior notes may find that their liquidity cushion against the issuer's bankruptcy is adversely affected after the issuer sells senior notes into the market.

${ }^{25 s}$ Small-sized offerings are also potentially exempt under Rule 504 of Regulation D. Rule 504 allows issuers to issue up to one million dollars worth of securities; unlike Rules 505 and 506, Rule 504 does not impose any limitations on the number of purchasers. See Rule 504, Securities Act, 17 CFR § 230.504 (1996). Similarly, Regulation A allows certain issuers to raise up to five million dollars through a public offering without meeting the information requirements of Section 5; rather, issuers under Regulation $A$ must put forth an offering circular. See Rules 251-63, Regulation A, Securities Act, 17 CFR $§ 230.251-63$ (1996).

${ }^{156}$ See Section 2(11), Securities Act, codified at 15 USC $\$ 77 \mathrm{~b}(11)$.

${ }^{157}$ In Gilligan, Will \& Co v SEC, 267 F2d 461, 464-68 (2d Cir 1959), the Second Circuit held that an investor who sought to resell restricted securities ten months after purchase from the issuer because the issuer's circumstances had changed lacked investment motive and, therefore, was participating in the issuer's original distribution as an underwriter.

${ }^{15}$ See, for example, A.A. Sommer, Jr., Considerations Leading to the Adoption of Rule
} 
tainty for investors seeking to resell their restricted securities in the public capital markets, the SEC instituted Rule 144 in 1972. ${ }^{159}$ Rule 144 provides that investors meeting the rule's twoyear holding period, ${ }^{160}$ volume limitation, ${ }^{161}$ information, ${ }^{162}$ and manner of sale requirements ${ }^{163}$ are not Section 2(11) underwriters and therefore may take advantage of the Section $4(1)$ exemption to resell restricted securities into the public capital markets. ${ }^{164}$ Through Rule 144, securities sold in one of the transaction exemptions to Section 5 may eventually become freely traded in a public market.

Suppose Midco, a relatively small company, made a private placement of $\$ 5$ million common stock in 1980 with thirty individual investors ${ }^{165}$ and today trades on the over-the-counter "pink sheets" market and has assets worth only $\$ 4$ million and fewer than five hundred shareholders of record. ${ }^{166}$ Under Rule 144 and Section 4(1), investors may freely trade Midco's securities without any affirmative information disclosure requirements from either the Securities Act or Exchange Act. ${ }^{167}$ This is despite the fact that, without information and given the thin nature of the trad-

144, $67 \mathrm{Nw}$ U L Rev 65, 69 (Supp 1972). Even without investment motive, however, so long as the resale takes place within the same scope as the original offering, the resale is not considered a "distribution." Therefore, where investor $\mathrm{X}$ purchases bonds from Realco through a private placement to only accredited investors, so long as X resells only to other accredited investors, the private placement exemption is met and $X$ is not considered an underwriter under Section 2(11). See Cox, Casebook at 455-57 (cited in note 54).

${ }^{259}$ See Adoption of Rule 144, SEC Securities Act Release No 5223, 37 Fed Reg 591 (Jan 11, 1972).

${ }_{160}$ Rule 144(d) requires that a minimum of two years must elapse between the date of acquisition from the issuer (or the issuer's affiliate) and the resale of securities for Rule 144 to apply. Rule 144(d), Securities Act, 17 CFR § 230.144(d) (1996).

${ }^{165}$ See Rule 144(e), Securities Act, 17 CFR § 230.144(e) (1996) (providing different volume limitations for affiliates and nonaffiliates of the issuer).

${ }^{152}$ See Rule 144(c), Securities Act, 17 CFR \& 230.144(c) (1996) (detailing the requirement that there exist adequate public information on the issuer of the restricted securities).

${ }^{1 \circledast 5}$ See Rule 144(f), Securities Act, $17 \mathrm{CFR} \S 230.144$ (f) (1996) (requiring that the restricted securities be resold in "broker's transactions" as defined in Rule 144(g), Securities Act, 17 CFR $\S 230.144(\mathrm{~g})$ (1996)). Notice of the proposed sale must also be filed with the SEC under Rule 144(h), Securities Act, 17 CFR § 230.144(h) (1996).

${ }^{164}$ See Rule 144(b), Securities Act, 17 CFR $\$ 230.144(b)$ (1996). Rule 144 also requires that a notice of the proposed sales be filed with the SEC. See Rule 144(h), Securities Act, 17 CFR $\S 230.144(\mathrm{~h})$ (1996). Three years after the purchase from the issuer, however, nonaffiliates may ignore the volume limitation, information, manner of sale, and notice requirements of Rule 144. See Rule 144(k), Securities Act, 17 CFR § 230.144(k) (1996).

${ }^{165}$ Midco may make this sale using Rule 505's private placement exemption, for example. See Rule 505, Securities Act, 17 CFR \& 230.505 (1996).

${ }^{366} \mathrm{Midco}$, as a result, is not required under Section 13 of the Exchange Act to make periodic filings with the SEC. See Section 13, Exchange Act, codified at 15 USC $\$ 78 \mathrm{~m}$.

${ }^{157}$ Note, however, that Rule 15c2-11 of the Exchange Act, 17 CFR \& 240.15c2-11 (1996), may impose some information requirements on broker-dealers. See note 246. 
ing market for such a small issue of securities, investors are at high risk for fraud and speculative pricing.

On the other hand, suppose Fidco is a large, Exchange-Act reporting multinational company with billions in assets and $\$ 10$ billion in publicly traded common stock. Fidco chooses in early 1997 to make a private placement of $\$ 5$ million of its common stock. Because of the transaction focus of the Securities Act, the private placement common stock is restricted even though an active public market exists for the same class of common stock. Although both sets of common stock offer identical risks, returns, and voting rights from the investors' standpoint, the Securities Act's transaction focus forces the trading status of the shares to turn on their path into the market. Comparing Midco and Fidco, the transaction focus of the Securities Act allows shares of Midco to be freely traded, even though no public information exists on the stocks simply because the shares were sold a number of years in the past; on the other hand, Fidco private placement shares are not tradable, even though investors have a wealth of information on Fidco.

In summary, the current Securities Act regime is constructed with the purpose of forcing issuers to provide information on a transaction-focused basis. It is, however, puzzling that the focus is on issuers and not on investors. ${ }^{168}$ Investor protection is the primary goal of securities regulation. A status-based regime that focused on providing information to investors and tailored regulation to the amount of information already available in the market on a particular issuer may better serve this goal of investor protection. Where information is lacking-perhaps because the issuer has only sold securities through private placement transactions-resales should be limited, perhaps to only institutional investors. On the other hand, where information on the issuer is abundant, both issuers and investors should be allowed to sell securities freely. If the offering of new securities alters the company's capitalization and valuation, the offering should be treated as a significant company event and disclosed to all investors and not only to offerees and purchasers of the particular transaction. ${ }^{169}$ As the next Section discusses, the Exchange Act, in fact, takes a status-based approach, as embodied in the periodic reporting requirements.

\footnotetext{
${ }^{168}$ See, for example, Cohen, 79 Harv L Rev at 1341-42 (cited in note 3).

${ }^{16}$ Perhaps companies can satisfy this disclosure requirement through the Form 8-K filing.
} 
2. Exchange Act.

In contrast to the Securities Act, the Exchange Act focuses on the secondary markets, where millions of securities, involving a wide variety of amounts and parties, are exchanged daily. ${ }^{170}$ Following the rationale of the Securities Act's resale provisions, individual investors are not required to provide information on a transaction-by-transaction basis. The information requirements of the Exchange Act instead work to ensure that companies provide the markets and the SEC periodically with an adequate amount of information. The amount of information required depends on the particular status of the company. Section 13 of the Exchange Act imposes periodic reporting requirements on all companies registered on any national securities exchange under Section 12(b); ${ }^{171}$ Section 13, similarly, results in periodic reporting requirements pursuant to Section 12(g) for companies with greater than 500 shareholders of record for any given class of securities and with assets totaling more than $\$ 10$ million. ${ }^{172}$ Finally, Section 15(d) of the Exchange Act imposes periodic reporting requirements for new initial public offering companies until the first fiscal year in which the company has fewer than 300 shareholders of record. ${ }^{173}$

Under the Exchange Act's periodic reporting requirements, issuers must file with the SEC annual Form 10-K, quarterly Form 10-Q, and occasional Form 8-K documents. ${ }^{174}$ The SEC's EDGAR system provides investors an electronic means of accessing this information directly. ${ }^{175}$ Aimed at the secondary market as a whole, Exchange Act disclosure relies on the ability of investment analysts and investors to access information filed with the SEC.

\section{B. The Advisory Committee Proposal}

In response to the complexities and tensions created by the current regime's dual transaction- and status-based approaches,

\footnotetext{
${ }^{170}$ Given that the equity trading markets were thirty-five times larger than the primary markets as of 1995, the Exchange Act's regulations cover a much wider scope of transactions than the Securities Act. See Advisory Committee Report at 14 \& a 4 (cited in note 13).

${ }^{171}$ Section 13, Exchange Act, codified at 15 USC \& 78m; Section 12(b), Exchange Act, codified at 15 USC § 781(b).

${ }^{172}$ Section 13, Exchange Act, codified at 15 USC § 78m; Section 12(g), Exchange Act, codified at 15 USCA § 78l(g), as applied by Rule 12g-1, Exchange Act, 17 CFR § 240.12g-1 (1996) (raising the asset requirement to $\$ 10$ million).

${ }^{173}$ Section 15(d), Exchange Act, codified at 15 USC \$ 780(d).

${ }^{17}$ See note 7 (describing periodic reporting requirements).

${ }^{175}$ See note 123 (citing sources on EDGAR).
} 
the SEC's Advisory Committee and other commentators have put forth several reform proposals aimed at formally instituting company registration and disclosure. The Advisory Committee Report, however, presents a curious mixture of proposals directly related to creating a company registration system and other proposals not necessarily dependent on company registration. Some of these peripheral reforms are in part justified by the impact of a shift toward company registration on disclosure quality, due diligence investigations, and the timing of the securities registration process. Others, however, stand almost completely independent of the company registration system and should be analyzed separately. To the extent they prove worthwhile, the SEC and Congress may wish to apply such reforms to the current Securities Act regime even should company registration never become implemented. This Section (1) discusses the reform proposals directly related to company registration; (2) reviews the peripheral reforms; and (3) finally discusses the shortcomings of the Advisory Committee's Report.

\section{Company registration.}

At its heart, the Advisory Committee's proposed company registration system establishes a form of continuous shelf registration system. ${ }^{176}$ Companies entering the company registration regime are required to file a new Form C-1 with the SEC containing "a generic description of the type of securities the issuer anticipated issuing, as well as a general discussion of its financing plans."177 After the initial filing of Form C-1, the information in the Form C-1 document would be kept current by incorporating all existing Exchange Act filings, including Form 10-K, 10-Q, and 8-K filings. ${ }^{178}$ The continuous registration statement for Section 5 and Section 11 purposes then consists of the original Form C-1 and all incorporated documents. ${ }^{179}$ Company registration is

\footnotetext{
${ }^{176}$ See Advisory Committee Report at 20 (cited in note 13) (“[T] $]$ he companyregistration system essentially will make the Form C-1 the equivalent of a shelf registration statement that is applicable on a continuous basis for all future offerings.").

${ }^{17}$ Id at 80 .

${ }^{178}$ Id at 22 ("Much like today, companies also would file Exchange Act reports, which would automatically be incorporated into the Form C-1, and the information in the company's public file would then form the primary basis for decisions by the investing public with respect to a registered company's securities."); id at 80-81 (describing company registration scheme in more detail).

${ }^{179}$ Id at 80-81. The two main benefits claimed by the Advisory Committee over today's shelf registration under Rule 415 are that: "[T] tion system on the amount of securities that could be registered would be eliminated, as would the need to file a new registration statement to register additional securities." Id at 9. Rule $\mathbf{4 1 5}$ currently allows $\mathrm{S}-3$ companies to register only up to $\mathbf{1 0}$ percent of a com-
} 
targeted initially only at "pilot" companies that meet the following requirements: the "completion of an initial public offering, a two-year reporting history, $\$ 75$ million public float, and a class of securities listed on the New York Stock Exchange, the American Stock Exchange, or the NASDAQ-NMS stock market."180

Although providing a new continuous shelf-offering system, the Advisory Committee's proposal retains a significant transaction-based element. The proposal divides and regulates companies based on the nature of the offering transaction. ${ }^{181}$ Four types of equity offerings are possible. De minimis equity offerings are defined as an offering of less than 3 percent of the public float of the security in a period of any three business days. Routine equity offerings involve greater than or equal to 3 percent and less than 20 percent of the public float. Nonroutine equity offerings consist of offerings greater than or equal to 20 percent and less than 40 percent of the public float. Finally, extraordinary equity offerings include all offerings greater than or equal to 40 percent of the public float. The proposal also treats all nonconvertible debt offerings separately as a class.

During an offering of securities, ${ }^{182}$ issuers are required to file transaction-specific information on the offering-including the offering amount, the identity of selling security holders, the use of proceeds, and the plan of distribution-with the SEC, either as a Form 8-K filing or a prospectus supplement, depending on the type of transaction. ${ }^{183}$ For non-de minimis equity offerings, issuers must file a Form 8-K statement with the SEC. ${ }^{184}$ Through the Form 8-K filing, the transaction-specific information is incorporated into the registration statement and brought under the coverage of Section 11 liability. ${ }^{185}$ Issuers making a de minimis transaction, in contrast, may elect at their discretion to forego a Form 8-K filing and file a prospectus supplement with the SEC instead. Because the prospectus supplement does not become

pany's outstanding voting equity for "at the market" offerings; furthermore, the company must reasonably expect to issue its shelf-registered equity within two years of its registration. See Rule 415, Securities Act, 17 CFR § 230.415 (1996).

${ }^{200}$ Advisory Committee Report at 93 (cited in note 13). Roughly 30 percent of all reporting companies qualify for the pilot. Id at 95 .

${ }^{281}$ Id at 24-27.

${ }^{122}$ Note that initial public offerings and offerings of securities not valued on the basis of the issuer's business and financial information (for example, asset-based or special purpose issues) are not eligible for company registration. Id at 99-100.

${ }^{125}$ Id at 22-23.

${ }^{12}$ Id at 23.

${ }^{25}$ Id. The Advisory Committee also argues that the Form 8-K will serve as a focal point to facilitate due diligence inquiries of underwriters, auditors, and other third parties. Id at 82. 
part of the registration statement, the transaction-specific information comes only under Section 12(a)(2) liability protection. ${ }^{186}$ In all cases where a Form $8-\mathrm{K}$ is filed, updating information on material company-related disclosure not yet in the Form C-1 public file would be required to be filed some period of time before the sale to provide the market with an ample period to take this information into account. ${ }^{187}$ Issuers of all types of transactions must also make a post-effective amendment to the registration statement in the event that the company undergoes a "fundamental change." ${ }^{188}$

For issuers under the company registration system, the gunjumping rules governing pre-effective offers to potential investors are effectively eliminated. ${ }^{189}$ The current gun-jumping rules under Section 5 impose large costs. Reporting companies in particular suffer from the double burden of providing material information to the investing public while at the same time, before a public offering, avoiding anything that might condition the market. ${ }^{190}$ For example, where the offering may radically change the value of the company for current investors, reporting companies are placed in a bind as to whether to inform the current investors of the offering or remain silent for fear of advertising the offering prior to the effective date. Furthermore, it is unclear what is gained by restricting pre-offering information for reporting companies. In particular, the large, well followed pilot companies typically have many institutional owners as well as investment analysts tracking the performance and valuation of the pilot companies' securities. ${ }^{191}$ For such companies, therefore, there exists little risk that pre-effective information disclosures from the issuer will cause the market to launch into a speculative frenzy. ${ }^{192}$ Even if smaller investors are present, the weight of in-

\footnotetext{
${ }^{186}$ Issuers pay a minor registration fee when they first file their Form C-1. Thereafter, the system would operate on a "pay-as-you-go" basis, depending on the amount of securities issued. Id at 22.

${ }^{287} \mathrm{Id}$ at 24.

- ${ }^{288}$ Id at 25-27, 83. This parallels the requirement imposed under current Rule 415 that issuers comply with item 512(a) of Regulation S-K to make a post-effective amendment to reflect any fundamental changes. See Rule 415(a)(3), Securities Act, 17 CFR \& 230.415(a)(3) (1996).

${ }^{29}$ See Advisory Committee Report at 16 (cited in note 13).

${ }^{200}$ Id ("Statutory limitations and regulatory restrictions on solicitation activities prior to and during the registration process make it difficult for reporting companies to distinguish between permitted and prohibited market communications.").

${ }^{291}$ See note 54 (detailing data on the incidence of analysts for companies) and note 58 (detailing data on the incidence of institutional investors).

${ }^{192}$ See Guidelines for the Release of Information by Issuers Whose Securities Are in Registration, SEC Release No 5180, 1 Fed Sec L Rptr (CCH) II 3056 (Aug 16, 1971) (listing rationale of gun-jumping rules to stop conditioning market).
} 
stitutional money will maintain the secondary market stock price of the issuer at or near its fundamental value. This will force the issuer in turn to keep its offering price also anchored to the company's fundamental value. For pilot companies, then, the fear of unduly conditioning the market prior to the offering seems unfounded and unnecessary, especially where this fear chills the normal flow of information into the market. ${ }^{193}$

With each new issue of securities, the Advisory Committee's proposal would allow issuers to fulfill Section 5's prospectus delivery requirement through a document of its own choosing. According to the Committee, this change gives issuers the flexibility to fashion the prospectus more as a marketing document, providing more readable and understandable information to investors. ${ }^{194}$ Depending on the type of transaction, both general company as well as transaction-specific information would be incorporated by reference into the statutory prospectus. ${ }^{195}$ Issuers of de minimis and routine offerings, for instance, would be allowed to incorporate both transaction-related and company information into the statutory prospectus by reference. Issuers of nonroutine and extraordinary offerings, in contrast, would not be allowed to incorporate transactional information by reference except for prospectuses targeting accredited investors. ${ }^{196}$ For all but ex-

\footnotetext{
${ }^{13}$ Note, however, that the elimination of the gun-jumping rules is not necessarily a feature of the company registration process. This elimination parallels the reduced importance of gun-jumping rules in today's shelf registration system. Companies under Rule 415 must obey the gun-jumping rules while obtaining their universal shelf registration; thereafter, however, they may issue securities freely without concern for the gun-jumping rules. Furthermore, nothing in today's registration process is inconsistent with a reform to eliminate only the gun-jumping aspects of the system. Congress or the SEC could maintain the current transaction-based framework and simply do away with their gunjumping rule aspect.

${ }^{19}$ Advisory Committee Report at 83 (cited in note 13) ("A principal goal of the Committee has been to recast the prospectus from what in many cases is its current function-a document prepared to comply with regulatory requirements and to provide the issuer with a defense in the event of litigation, which often is not sent to investors until after the investment decision is made-into a tool to convey meaningful information at the time of the investment decision."). Note, however, that "plain English" reform of prospectuses is not a unique feature of company registration. The SEC, in fact, recently instituted a pilot program aimed at introducing more "plain English" prospectuses within the current regime. See Bell Atlantic, NYNEX First to File "Plain English" Disclosure Documents, 28 Sec Reg L Rep (Sept 13, 1996); Disclosure: SEC Plain English Initiative is One of Levitt's "Highest Priorities", 28 Sec Reg L Rep 971 (Aug 9, 1996).

${ }^{150}$ Note that where the issuer is offering a new security, the Advisory Committee would require the issuer to disclose the terms of the new security and the specific risks of the security directly to potential investors, without the benefit of incorporation by reference. Advisory Committee Report at 83 (cited in note 13).

${ }^{156}$ As with S-3 offering prospectuses, however, pilot companies would be allowed to incorporate nontransactional, company-related information by reference into the prospectus. Id at 87. The Advisory Committee, furthermore, would require that issuers deliver
} 
traordinary transactions, the SEC would abstain from conducting any direct review of the Form C-1 or transactional disclosures prior to an offering; the SEC, however, would retain the right to review periodic Exchange Act disclosures. ${ }^{197}$

In addition to continuous shelf registration and prospectusdelivery reform, the Advisory Committee's proposal presents one final major feature: the elimination of most of the complex resale limitations surrounding restricted securities. ${ }^{198}$ Because securities of issuers within the company registration system are registered already, there is little need to issue them through a private placement. The Advisory Committee, however, remained ambivalent toward the exact role private placements and other exemptions should play in the company registration system. ${ }^{199}$ Rather than decide the issue, the Advisory Committee instead chose to allow pilot companies to elect either to join the full company registration system or opt for a modified form of company registration. Under the full company registration system, issuers and affiliates would lose the right to use any of the transactional exemptions except for certain exempt securities. ${ }^{200}$ Issuers, however, would be able to make use of a "limited placement" and sell a limited amount of restricted securities to one or more accredited investors. ${ }^{201}$ Significantly, the Advisory Committee recommends eliminating any fixed holding period for the limited exemption securities; instead, securities would remain restricted until full disclosure is made to the public in a Form 8-K or other public filing. ${ }^{202}$ Full company registration companies would also be allowed to make private placements of nonconvertible debt securities to institutions during the pilot period. ${ }^{203}$ Issuers selecting the modified regime, on the other hand, would retain the right to engage in one of the current regime's transaction exemptions

this prospectus before investors purchase the security. Id.

${ }^{197}$ Id at 22, 89-90. Under the current system, the SEC may choose to review any registration document. The SEC, however, pursues a policy of selective review for all filings other than initial public offering filings. From 1994 to 1995, for example, the SEC reviewed 13.9 percent of the total number of non-shelf S-3 filings. Id at 47-48.

${ }^{198}$ Id at 8-9, 17, 22.

${ }^{199}$ Id at 100 ("The Committee engaged in considerable discussion on whether companies participating in the company-registration system should be able to rely on exemptions for private placements and other transactions that are available today from the registration and liability provisions of the Securities Act.").

${ }^{200}$ Id at 101.

${ }^{201}$ Id at 102. Securities sold as part of a limited placement would be restricted. Investors would be able to resell such securities only after "full disclosure is provided to the public through a Form 8-K or other public filing of such information and its inclusion in the Form C-1." Id.

${ }^{20}$ Id.

${ }^{203}$ Id at 81. 
separate from the company registration system. ${ }^{204}$ Even under the modified system, however, the decreased cost of making a registered offering under the company system would greatly diminish the volume of the transactional exemptions, reducing the importance of the complex resale restrictions. ${ }^{205}$

The core of the Advisory Committee's proposals brings the current Securities Act regime into a company registration format through the perpetual extension of the shelf registration. Form C-1 essentially represents the continuous shelf registration document. Combined with a broad concept of incorporation by reference into the prospectus, the Advisory Committee's proposal makes it relatively inexpensive for registered companies seeking to issue securities through a public offering. Although some securities of the same class may still face disparate treatment as restricted securities, the Advisory Committee's proposal, by reducing the role of private placements and other transaction exemptions from Section 5, does achieve equal treatment for most securities of the same company.

\section{Peripheral proposals.}

In addition to introducing continuous shelf registration, the Advisory Committee suggests a number of peripheral reforms designed to enhance and complement the move toward company registration. None of these reforms is necessary to company registration; furthermore, they may also be easily applied to today's transaction-based regime. ${ }^{206}$ The Advisory Committee, nevertheless, justifies these proposals as required to strengthen investor protections in light of the impact of a company registration system on disclosure and due diligence practices. ${ }^{207}$

First, the Advisory Committee calls for an expansion of antifraud liability covering disclosure documents. ${ }^{208}$ Antifraud liability is expanded by extending the reach of both Section 11 and Section 12(a)(2) of the Securities Act. Because the company registration proposal requires that transaction-specific information and material company updates be filed as an amendment to the registration statement under Form $8-\mathrm{K}$ for all but debt and de minimis equity offerings, this information comes within the scope

204 Id at 101-02.

${ }^{\infty}$ Id at $100-01$.

${ }^{206}$ Indeed, some members of the Advisory Committee have suggested that these reforms be applied independent of the company registration system to today's universal shelf registration process. Id at 109.

${ }^{20}$ Id at 102-03.

${ }^{20}$ Id at 110-13. 
of Section 11 liability. The Advisory Committee's proposal therefore expands the scope of liability currently applied to certain updates to Rule 415 shelf offering filings. In particular, issuers making a Rule 415 shelf registration under the current regime must provide updated information in the form of either a prospectus supplement (for material, nonfundamental changes not relating to the plan of distribution $)^{209}$ or an amendment to the registration statement (for fundamental changes or material changes relating to the plan of distribution). ${ }^{210}$ Where an issuer conducting a shelf registration, therefore, potentially bears Section 11 liability only for fundamental changes or material changes to the plan of distribution, pilot companies under the company registration system will face Section 11 liability for all material company updates. Furthermore, although the company registration proposal allows issuers to treat their own selling documents as the "statutory prospectus," this feature of the proposal introduces the possibility of Section 12(a)(2) liability on . what in the current system would be considered "free writing" and not a prospectus for purposes of either the gun-jumping rules or antifraud liability. ${ }^{211}$

As discussed in Section I, however, it is unclear that greater antifraud liability advances investor protection goals. ${ }^{212}$ In the face of high costs due to frivolous litigation, more antifraud liability may actually increase the cost of going public. On the other hand, because a company registration system provides issuers the ability to bring securities to market relatively quickly,

\footnotetext{
${ }^{209}$ Although not directly imposed under Rule 415, issuers may face a duty to update the prospectus for material changes from Section 12(a)(2), for example, that imposes antifraud liability for material misstatements or omissions necessary in light of prior statements not to make the prospectus materially misleading. See Section 12(a)(2), Securities Act, codified at 15 USCA § 77l(a)(2). Rule 424(b), moreover, imposes a requirement that an updated prospectus embodying "substantive changes from or additions to a previously filed prospectus" must be filed with the SEC. See Rule 424(b), Securities Act, 17 CFR $\S 230.424(\mathrm{~b})$ (1996).

${ }^{210}$ See Rule 415(a)(3), Securities Act, 17 CFR § 230.415(a)(3) (1996) ("The registrant furnishes the undertakings required by Item 512(a) of Regulation S-K . . . .); Item 512(a)(ii), Regulation S-K, Securities Act, 17 CFR § 229.512(a)(ii) (imposing an obligation on issuers to "reflect in the prospectus any facts or events arising after the effective date of the registration statement ... which, individually or in the aggregate, represent a fundamental change in the information set forth in the registration statement"). Material changes to the plan of distribution must also be filed as a post-effective amendment to the registration system. See Item 512(a)(iii), Regulation S-K, Securities Act, 17 CFR $\S 229.512$ (a)(iii). Unlike amendments to the registration statement, which are subject to Section 11 liability, supplements to the prospectus bear only Section 12(a)(2) liability risk. See generally Louis Loss and Joel Seligman, Fundamentals of Securities Regulation 11415 (Little, Brown 3d ed 1995) (describing the required undertakings under Rule 415).

${ }^{211}$ Loss and Seligman, Securities Regulation at 112-13 (cited in note 210).

${ }^{212}$ See text accompanying notes $34-39$.
} 
the argument goes, third parties may not have time to conduct an adequate due diligence investigation. Incorporation by reference of Exchange Act filings, which are typically subject only to Rule 10b-5 liability, into Securities Act filings may also reduce the quality of disclosures. ${ }^{213}$ More inaccurate and incomplete information disclosures may result. ${ }^{214}$ This argument, however, ignores the possibility that alternative market-based mechanisms exist to deter against fraudulent or incomplete disclosures. ${ }^{215}$ Given that antifraud liability acts as only one substitute for these other mechanisms, the need for liability diminishes as the efficacy of the other mechanisms rises. The market-based mechanisms, moreover, are strongest for larger, highly capitalized companies that are well followed in the securities markets. Although the argument for increased liability may prove correct on average for Exchange Act filings, the Advisory Committee Report must take into account these differences among companies. ${ }^{216}$

${ }^{213}$ See Gerald S. Backman and Stephen E. Kim, From disclosure to registration, Bus L Today 53, 55 (Jan/Feb 1996) (noting that "a 1993 ABA Task Force Report asserted that diligence may consist of no more than a phone discussion with the issuer the night before a shelf takedown, consultation with the underwriter's equity analyst following the issuer and perhaps a quick check of any available ratings information").

It remains somewhat ambiguous whether Exchange Act documents incorporated by reference into Securities Act filings are subject to Section 11 liability. See, for example, Coffee, 52 Wash \& Lee L Rev at 1160 n 45 (cited in note 11) (noting that although Section 11 applies to the annual report on Form 10-K incorporated by reference into a Securities Act filing, debate exists as to whether Section 11 liability applies to interim Exchange Act filings).

${ }^{24}$ Milton Cohen, for example, argues for an expanded version of Section 18 of the Exchange Act's antifraud prohibitions, including third-party liability and a negligence standard of care. Cohen contends that raising antifraud liability for all Exchange Act disclosures lessens the risk that incorporation by reference into a company registration system will result in offering disclosures of lower quality. See Cohen, 40 Bus Law at 988-90 (cited in note 3 ).

${ }^{215}$ See Section I.B.

${ }^{215}$ In their separate statement, Advisory Committee members Coffee, Greene, and Sonsini do present an argument that the due diligence defense for third parties should vary with the size and character of the offerings. See Advisory Committee Report at 39-40 (cited in note 13) (separate statement). As discussed below, however, it is unclear why disclosure or antifraud requirements should turn on the size of an individual offering transaction. See text accompanying notes 239-42. Although larger offerings involve a greater change in the capitalization of the issuer and perhaps also in the issuer's future prospects, the larger offering will also attract concomitantly greater attention from the investment community. Not only will investment analysts assess the issuers more closely, but the value of reputational certification from third-party intermediaries will also increase, leading issuers to expend more resources to hire more high-quality intermediaries to screen their offering. Coffee, Greene, and Sonsini are correct, nevertheless, to call for different levels of due diligence for companies of different "character," focusing on the high-speed use of shelf-offering transactions by S-3 companies. Even here, however, they incorrectly rely upon the inability of certifiers or gatekeepers to screen issuers adequately during rapid access offerings as their rationale. See id at $\mathbf{4 0}$ (separate state- 
Second, aware of the role third-party liability plays in controlling the incidence of fraud, the Advisory Committee recommends providing clearer guidelines for third parties who are associated with the offering and who act as gatekeepers. ${ }^{217}$ Under Section 11 of the Securities Act, underwriters are potentially liable for material misstatements and omissions in the prospectus unless they meet a due diligence defense. ${ }^{218}$ The Committee suggests "clarifying" the due diligence burden that underwriters and others must undergo to escape this liability. ${ }^{219}$ Given the expanded emphasis on gatekeepers, the Committee also suggests limiting the definition of "underwriters" to protect non-securities professionals from potential liability. ${ }^{220}$ But as with the other peripheral reforms, the expansion and clarification of gatekeeper duties or the definition of "underwriter" are neither unique to nor necessary for a company registration system. Moreover, additional underwriter duties may not necessarily enhance investor protection. To the extent investors value the underwriters' gatekeeper role, they will pay more for securities associated with such a gatekeeper. Issuers, as a result, will have an incentive to provide underwriters with adequate opportunity to conduct their gatekeeper investigation. Where investors, however, do not value underwriters as gatekeepers, imposing legal liability may result in costly investigation that elevates the transaction cost of an offering without much benefit to investors.

Third, the Advisory Committee Report argues that its proposed company registration system generates more timely dissemination of information to investors and more readable and understandable prospectuses. ${ }^{221}$ Under the proposal, material updates to general company information are required to be filed under Form 8-K some period before the first sale of securities for

ment) ("Gatekeeper liability makes sense only when the gatekeeper is placed in a position to take effective preventive action."). Where the market values such certification, issuers will voluntarily provide third parties with the opportunity to engage in a gatekeeping role; otherwise, the market will penalize the issuer with a greater discount for the issuer's shares. Due diligence should vary based on the character of the issuer; this evaluation, however, should not revolve around size or timing of the offering, but rather on the presence of alternative antifraud mechanisms as identified above.

${ }^{217}$ Id at 113-17.

${ }^{218}$ See Section 11(b), Securities Act, codified at 15 USC $\S 77 \mathrm{k}(\mathrm{b})$.

${ }^{219}$ Advisory Committee Report at 114-15 (cited in note 13).

${ }^{200}$ Id at 97 (proposing to limit the statutory definition of underwriter to broker-dealers acting on behalf of the issuer or affiliate in a distribution).

${ }^{221}$ Id at 78-88. Under the current shelf registration system, issuers need only file a prospectus supplement containing updating information within two days after actual shelf registration takedown sales occur. See Rule 424(b)(2), Securities Act, 17 CFR $\S 230.424(\mathrm{~b})(2)(1996)$. 
all but nonconvertible debt and de minimis equity offerings of securities. ${ }^{222}$ The Committee therefore argues that the market receives this information sooner than under the current regime where information oftentimes arrives only with the final prospectus at the confirmation of sale, after the investor has made its purchase decision. Relying on the efficient markets hypothesis, the Committee argues that once this information is in the SEC's public file, institutional investors and others may freely examine and assess it before making their purchase decisions. ${ }^{223}$

Although important to ensure that investors receive information before they make their investment decisions, the Advisory Committee's information-delivery reform is not tied to a company registration system. For example, simply requiring that the final prospectus be delivered before investors make their purchase decisions accomplishes the same result under the current system. While not lacking merit, the Committee's proposal is separate from the company registration proposal. ${ }^{224}$

Fourth, the Advisory Committee's proposal reduces the scope of affiliate resale restrictions. Under Section 2(11), all those selling for "any person directly or indirectly controlling or controlled by the issuer, or any person under direct or indirect common control with the issuer" are considered underwriters. ${ }^{225}$ Control persons under the current system, therefore, are ineligible for Section 4(1)'s exemption from the registration requirements of Section 5. Although somewhat ambiguous, the definition of control person today extends to cover a wide range of parties able to influence policy decisions at the issuer, including top executive officers and major shareholders. ${ }^{226}$ The Advisory Committee

${ }^{22}$ Advisory Committee Report at 23-27 (cited in note 13). The Advisory Committee defines a de minimis equity offering as involving less than three percent of the public float of the security in any period of three business days. Id at 24-25, 27. For nonconvertible debt and de minimis equity offerings, the information could be disclosed either on a Form $8-\mathrm{K}$-and become part of the registration statement-or as a prospectus supplement. Id at 25.

${ }^{223}$ Id at 78.

${ }^{22}$ The Advisory Committee also argues that a company registration system saves issuers the legal, accounting, underwriting, printing, filing fees, and other direct administrative costs associated with conducting a public offering today. Id at 17 . While true, these costs would also be saved through an expansion of the current shelf registration system. Indeed, as discussed above in the text, the main contribution of the Advisory Committee toward achieving a company registration regime is to institute what is essentially a perpetual shelf registration for registered companies. See text accompanying notes 176-205.

${ }^{2 \approx}$ See Section 2(11), Securities Act, codified at 15 USC § 77b(11).

${ }^{206}$ Control is not defined explicitly in the Securities Act. Rule 405 of the Act, however, does provide that control "means the possession, direct or indirect, of the power to direct or cause the direction of the management and policies of a person, whether through the 
would reduce the scope of affiliate registration to the CEO, inside directors, those persons with 20 percent of the voting power, and those with 10 percent of the voting power and at least one director on the board. ${ }^{227}$ Regardless of the merits of reducing those considered control persons under Section 2(11) for registration purposes, the Advisory Committee's proposal on affiliates is unrelated to company registration, and could just as easily be employed under today's regime.

Finally, the Advisory Committee makes a number of recommendations to enhance the value of the information disclosure requirements. ${ }^{228}$ The Committee, for example, would compel two members of a company's "top management" to certify to the SEC that they reviewed the information contained in the company's Form 10-K, 10-Q, and 8-K filings and that they are unaware of any misleading disclosures or omissions. ${ }^{229}$ Furthermore, the Committee recommends requiring management to prepare a report to the board of directors' audit committee that would describe "the company's practices and procedures, if any, to ensure the integrity of all periodic and current reports filed under the Exchange Act." ${ }^{230}$ The Committee also proposes expanding the scope of required Form 8-K filings to include material developments relating to the rights of security holders, the resignation or removal of any of the top five executive officers, defaults of senior securities, sales of significant percentages of the company's outstanding stock, or warnings from an independent auditor that reliance on an audit report included in a previous filing is no longer permissible. ${ }^{231}$ Finally, the Committee would require a risk factor analysis within each company's annual Form 10-K filing. ${ }^{232}$

Although the merits of each of these disclosure-related reforms are debatable, many of them may in fact increase the value of information disclosure to investors. As with many of the other reforms contained in the Advisory Committee's report, however,

ownership of voting securities, by contract, or otherwise." Rule 405, Securities Act, 17 CFR § 230.405 (1996). Some courts, furthermore, have held that control embodies the ability to force the issuer and its officers and directors to provide the necessary signatures for a valid registration statement. See Pennaluna \& Co v SEC, 410 F2d 861, 865 (9th Cir 1969) (adopting "position to obtain" signatures test).

${ }^{2 m}$ See Advisory Committee Report at 98 (cited in note 13).

${ }^{2}$ Id at 29-31.

${ }^{22}$ Id at 30. Top management would include the chief executive officer, chief operating officer, chief financial officer, or chief accounting officer. Id.

${ }^{20}$ Id at 106-07. This report would be made public as an exhibit in the company's annual Form 10-K filing. Id at 106.

${ }^{2011}$ Id at 107-08.

${ }^{222}$ Id at 108-09. 
the Advisory Committee's suggested disclosure reforms could very well apply even under the current system to increase investor protection. Arguably, the increase in disclosure reforms and clarification of gatekeeper antifraud duties are a necessary byproduct of company registration. Because company registration may result in speedier offerings to the public, gatekeepers and management may lack the time to adequately police an offering. Additional legal requirements may therefore ensure that parties close to the offering take care to ensure truthful and complete disclosures. Note, however, that this problem exists today in the shelf registration process and is not necessarily unique to the formal company registration system.

\section{What's missing from the proposal.}

Stripped of its peripheral reforms, the Advisory Committee's central addition to the company registration framework is to introduce continuous shelf registration, reduce the prospectus delivery requirements, and deter issuers in most circumstances from using a private placement or other exempt offering in place of a public shelf offering. Although this certainly provides many of the benefits envisioned by Milton Cohen in his 1966 article, the Advisory Committee left several questions unanswered.

Most conspicuously, the Committee left ambiguous the ability of smaller, less followed companies to partake of the benefits of a company registration system. Excluded from the pilot program, small-size companies may eventually share in the company registration system with additional restrictions. ${ }^{233}$ The Advisory Committee Report notes that, at a minimum, privately held companies must undergo the entire initial public offering process before entering into the company registration system. ${ }^{234}$ Here, however, the arguments for company registration become much weaker. Particularly with the smallest of companies, the efficient market hypothesis may not hold true. Some smaller OTC companies trade only once-if not less-per day. ${ }^{235}$ This lack of liquidity, in turn, leads to less attention from institutional and

${ }^{223}$ The Advisory Committee did suggest that smaller companies may be able to take advantage of the company registration system, so long as additional protections are put into place. These additional protections could include traditional prospectus delivery, greater advance notice of transaction-specific information before any offering to investors, or possible SEC staff review of annual financial and other information before the offering. Id at $28,94$.

${ }^{24}$ Id at 93 ("The Committee believed that the current process for initial public offerings [ ] generally works well in assisting a company in the transition from a private to a public company.").

${ }^{225}$ See Dunkin, Bus Week at 82 (cited in note 47 ). 
other sophisticated investors. Accordingly, the market price of smaller companies' stock often may not reflect all publicly available information. At least for these companies, nonmarket mechanisms may need to supply entirely the information that potential investors need.

A company-based registration system may, therefore, find value in paralleling the different registration requirements in Forms S-1 through S-3. ${ }^{236}$ Where companies trade in an efficient market-S-3 companies, for example - a company registration system could rely heavily on the market to transmit information on the company to all investors. ${ }^{237}$ For such companies, simply filing periodic information disclosures with the SEC may be enough to ensure that all investors receive the necessary investment information; the prospectus delivery requirement could accordingly be eliminated altogether. At the other extreme, S-1 companies may not trade in an efficient market or may not trade in any pre-existing market whatsoever. For such companies, until a company registration statement is filed, prohibiting all trades except among close affiliates of the company or sophisticated investors may make sense. Even after a company registration statement is filed, concern over the efficiency of the market may require that a complete prospectus containing both general and transactional company-related information be sent to each prospective investor. S-2 companies, finally, may be treated somewhere in between these two extremes. S-2 companies may be allowed to issue securities off the company registration statement (under a continuous shelf registration), but under the condition that some amount of company-related information be included in the prospectus delivered to investors.

Rather than focus on the issue of nonpilot companies, the Advisory Committee's proposal instead reintroduces aspects of a transaction-based system, basing the information- and prospectus-delivery requirements on the size and type of offering transaction. ${ }^{238}$ The Advisory Committee mistakenly focuses on these

\footnotetext{
${ }^{266}$ See text accompanying notes 48-53 (describing the SEC's Form S-1, S-2, and S-3 division of companies for registration purposes).

${ }^{27}$ Interestingly, the Advisory Committee chose not to make all S-3 companies part of the pilot program. Advisory Committee Report at 94-95 (cited in note 13) (" $[1]$ t often takes at least two years following an IPO for a company and its management to become fully comfortable with the disclosure obligations of a public company and to have all their mechanisms for gathering and disseminating information in place and properly functioning."). This statement, however, calls into question why S-3 companies are currently allowed to incorporate by reference as much as they do. If two years truly is necessary to ensure an efficient market, S-3 companies should also be required to fulfill this two-year requirement.

${ }^{288}$ See text accompanying notes 182-97.
} 
transactional differences rather than on overall differences at the company level. Although two pilot companies may differ in the size of their equity offering, it is unclear why the amount of disclosure, the extent of antifraud liability, and prospectus delivery should also differ in a similar manner. The Advisory Committee argues that both nonroutine and extraordinary categories of transactions "because of their size, are likely to alter substantially the information previously provided to the market and to involve significant oral and written selling efforts." ${ }^{239}$ Companies that engage in nonroutine or extraordinary transactions, however, will also attract increased attention from securities industry professionals precisely because of the transaction's size. If the issuer's securities trade in an efficient market, this attention will ensure that information is disseminated both quickly and widely into the secondary market. For pilot companies engaged in nonroutine or extraordinary transactions, the efficient market hypothesis thus argues for fewer prospectus delivery requirements rather than the increased amount in the Advisory Committee's proposal. So long as information on the transaction is filed in some form with the SEC, the information will be absorbed into the market.

Professor John C. Coffee, Jr., a member of the Advisory Committee, has independently argued that disclosure should be aimed at individual investors "to the extent that investor attitudes toward risk are necessarily subjective. ${ }^{240}$ Coffee contends that the market values securities on a risk-neutral basis; as a result, risk-averse investors may want information other than the market price to determine the suitability of particular securities for their own taste for risk. ${ }^{241}$ Although investors may have an idea of a company's risk from past disclosures-including the annual report-nonroutine or extraordinary transactions may significantly alter the risk level of the company. ${ }^{242}$ To the extent Coffee is correct, disclosure directly to individual investors in cases of nonroutine or extraordinary issuer transactions may be necessary.

Coffee, however, misses two crucial points. First, investors who are risk-averse gain more than risk-neutral investors from reducing risk. Risk-averse investors, more than any other type of investor, will value the diversification of unsystematic risk provided by mutual funds and other institutional investors. Because

\footnotetext{
${ }^{*}$ Advisory Committee Report at 85 (cited in note 13).

${ }^{2 \omega}$ Coffee, 52 Wash \& Lee L Rev at 1167 (cited in note 11).

${ }^{2 *}$ See id.

${ }^{2 x 2}$ Id.
} 
most risk-averse investors will flock to the institutional investors, the danger of small, individual investors mispricing individual securities based on their own risk preferences is minimized. Second, for those few risk-averse individual investors remaining in the general securities markets, the growth of the Internet and other electronic media has greatly reduced the cost for such investors when gathering information on extraordinary transactions. ${ }^{243}$ Particularly for S-3 companies, the many analysts that follow such companies will undoubtedly report news of an extraordinary transaction to other investors and to the news media. The number of individual investors that truly benefit from direct delivery of prospectus information is accordingly small. Furthermore, it is unclear why the rest of the capital market must pay-through higher issue costs and greater uncertainty and delay-to subsidize the research efforts of these few investors.

Finally, the Advisory Committee's Report also drastically reduces the importance and role of private placements and other exemptions from Section 5's registration requirements. On the one hand, the diminished role of private placements makes sense. If the company itself and all of its associated securities are registered, exemptions from the registration requirements no longer are required. For several reasons developed in Section III below, however, it is unclear if society benefits from the complete elimination of private placements and the current restricted security system. The Committee does allow pilot companies in the full company registration system to make nonconvertible debt private placements and limited placement offerings. Moreover, pilot companies in the modified company registration system may engage in the full range of exempt offerings under Section 5. Although providing some possibility for exempt offerings, the Committee needs to consider more flexible measures designed to allow exempt transactions where both issuers and investors benefit from opting out of the company registration system. For example, the Advisory Committee recognizes that an issuer may wish to reveal confidential information only to a few select investors but not to the market as a whole. Allowing such transactions gives companies an incentive ex ante to invest in projects requiring confidentiality, bolstering both innovation and competition. ${ }^{244}$ Conversely, pressures that may distort the choice to do a

\footnotetext{
${ }^{2 * 3}$ For example, investors may now access detailed company-specific financial information and up-to-date financial indices on the Internet through www.wsj.com and www.marketedge.com among several other Internet content providers.

${ }^{24}$ The ability to maintain the confidentiality of business plans or other business-
} 
private placement-including differential antifraud liabilityshould be eliminated to ensure that issuers conduct an exempt offering only where society as a whole benefits. As Part III discusses, a status-based antifraud regime combined with today's private placement exemption from Section 5 accomplishes this goal.

\section{Impact of Company Registration}

The Advisory Committee's company registration suffers from one further fundamental flaw: although formally the Securities Act's transaction focus presents several problems, many of the SEC's reforms in the 1980s brought securities practice substantively closer to a company registration system. Although the Advisory Committee's continuous shelf proposal does complete the transformation of the Securities Act toward a formal statusbased registration regime, the benefit from this transformation is not as great as it would have been at the time of Milton Cohen's 1966 article. Furthermore, the uncertainty costs of introducing a new registration system, as well as potential costs due to the specter of increased frivolous litigation under the Advisory Committee's proposed expansion of antifraud liability, may outweigh this benefit. This Section details the shifts in the current regime over the past two decades that have already introduced many of the substantive aspects of company registration into the current system.

The differences between the transaction- and status-based regimes embodied within the Securities Act and Exchange Act may be divided into four major areas. First, information disclosure under a company registration system occurs periodically and whenever certain material events occur with respect to the company. Exchange Act reporting companies, for instance, must file with the SEC all material developments relating to changes in control, the purchase or sale of significant assets, changes in accountants, and bankruptcy on both Form 8-K and their periodic filings. ${ }^{245}$ Under the transaction-based Securities Act, however, information disclosure occurs only when a securities trans-

related information is important for at least two reasons. First, from an ex ante perspective, companies may be deterred from making innovative investments to the extent they realize that the securities laws will force them to reveal the innovation to other companies that then may simply "free ride" off the innovation ex post. Second, companies planning to engage in more vigorous competition with their rivals may also be deterred to the extent the securities laws force them to reveal their plans prematurely to the market and thereby to their competitors.

${ }^{265}$ See Form 8-K, Exchange Act, 5 Fed Sec L Rptr (CCH) III 31,001-04 (Jan 30, 1995). 
action occurs. Thus, where a company does not qualify as an Exchange Act reporting company but nevertheless has some class of securities publicly traded, the company may avoid information disclosures even where the information is highly relevant to present investors. ${ }^{246}$

Second, prior to the delivery of the statutory prospectus in the post-effective period, the transaction-based approach of the Securities Act strictly controls most forms of communication relating to the offering. Although oral communications may commence after the registration statement is initially filed with the SEC, additional "free writing" written materials are forbidden unless preceded by or accompanied with a final statutory prospectus after the registration statement has become effective. Because the Securities Act focuses on one particular transaction-the public offering of securities-it places great importance on ensuring that investors in the public offering transaction are given the required statutory prospectus information first, before other potentially more misleading information is received and little importance on the needs of investors generally in the company for free information disclosure. In contrast, the Exchange Act focuses on simply ensuring that an adequate amount of information for Exchange Act reporting companies exists in the market generally without any restrictions on other information disclosure.

Third, information in a company-based regime is distributed to the market as a whole. Several mechanisms exist to disseminate information to the market; for companies in an efficient market, simply filing the information with the SEC may be sufficient to disperse information quickly into the marketplace. Furthermore, because the market already incorporates information from prior filings, investors in an efficient market require only new information. The Securities Act, in contrast, emphasizes the distribution of information directly to potential investors. Transaction-based regimes place little reliance on the ability of individual investors to ferret out information from publicly available sources. Direct disclosure ensures that investors actually receive investment-related information. ${ }^{247}$ Moreover, to provide isolated

\footnotetext{
${ }^{24}$ Rule 15c2-11 of the Exchange Act, however, prohibits broker-dealers from publishing quotations in over-the-counter "pink sheet" markets without obtaining specified information on the company, including basic financial data. See Rule 15c2-11, Exchange Act, 17 CFR § 240.15c2-11 (1996).

${ }^{27}$ Of course, whether simply receiving investment information from the issuer alone provides investors with any guidance is debatable. Investors must look to other sources of information on the economy, the issuer's industry, and the issuer's competitors, and synthesize this with the company-specific information from the issuer to determine the value
} 
investors with full information, this disclosure must include not only new and current information, but also background and past information on the company.

The final difference between the status- and transactionbased approaches concerns the resale aftermarket. The transaction-based approach leads to disparate aftermarket treatment of securities of the same company and even of the same class. Shares of common stock issued through a public offering, for example, enjoy different liquidity than shares of the same class of common purchased in a private placement. For example, investors may not trade IBM common shares sold through a private placement until the Rule 144 holding period expires; identical IBM common shares sold through a public offering, however, may be freely traded. A company registration system would formally eliminate such distinctions, providing for equal treatment of all securities of the same class of a company.

These differences, however, are today more formal than real. Although embodying two separate approaches to regulation, the Securities Act and Exchange Act have both moved in substance much closer to a purely status-based approach over the past twenty years. Several major changes account for this shift, including: the integrated disclosure system; incorporation by reference; shelf registration; and the Qualified Institutional Buyer ("QIB") market. Each is discussed below in turn.

In 1982, the SEC adopted the current integrated disclosure system. ${ }^{248}$ Realizing that investors require the same information in making a decision to purchase securities-whether in an offering from the company or in the secondary market-the SEC established a core set of common information items within Regulations S-K and S-X, which the various forms within the Securities Act and Exchange Act reference. ${ }^{249}$ For example, Item 303 of Regulation S-K sets forth the requirements for the Management Discussion and Analysis of Financial Condition and Results of Operation disclosure. ${ }^{250}$ Both Form S-1 of the Securities Act and Form 10-K of the Exchange Act include Item 303 in their filing provisions. ${ }^{251}$

of an investment in the issuer. Most individual investors, however, lack the financial ability, time, and resources to conduct such an analysis.

${ }^{213}$ See Adoption of Integrated Disclosure System, Securities Act Release No 6383, 47 Fed Reg 11,380 (Mar 16, 1982).

${ }^{29}$ Regulation S-K, Securities Act, 17 CFR § 229 (1996); Regulation S-X, Securities Act, 17 CFR § 210 (1996).

${ }^{200}$ See Item 303, Regulation S-K, Securities Act, 17 CFR § 229.303 (1996).

${ }^{251}$ See Form S-1 (cited in note 16); Form 10-K, Item 7, Exchange Act, 5 Fed Sec L Rptr (CCH) II 31,104 (Jan 30, 1995). 
That same year, the SEC also provided that certain Securities Act registration filings could incorporate by reference some of their required information disclosure from parallel sections in the Exchange Act's periodic disclosure documents, depending on whether the issuer qualified for Form S-1, S-2, or S-3. ${ }^{252}$ The advent of integrated disclosure, combined with incorporation by reference, dramatically reduced the cost of putting together offering documents for S-2 and S-3 companies. ${ }^{253}$ Because many of the individual disclosure items in the registration documents and the Exchange Act documents refer to identical Regulation S-K or S-X items, incorporation by reference does not result in any different type of disclosure. ${ }^{254}$ This both reduces the cost of putting together a registration filing and accelerates the speed of conducting a public offering. Furthermore, if issuers who take advantage of incorporation by reference are well capitalized and followed by many analysts, the information contained in all disclosure documents will be reflected in the market price of the company. ${ }^{255}$ At the extreme, where all information in the registration document is incorporated by reference from Exchange Act documents-as under the Advisory Committee's proposal-no additional work is necessary to put together a registration document. The greater the incorporation by reference, therefore, the closer the current system moves in substance toward a company registration system. ${ }^{256}$

In 1983 , the SEC also modified Rule $415,{ }^{257}$ providing for shelf registration for issuers qualifying for Form S-3 registra-

\footnotetext{
${ }^{252}$ See Securities Act Release No 6383 (cited in note 248 ).

${ }^{2 x}$ See Coffee, 52 Wash \& Lee L Rev at 1159 (cited in note 11) ("Shelf registration and incorporation by reference really implied that disclosure to the market through ' 34 filings replaced disclosure to individual investors through prospectuses.").

${ }^{24}$ Note, however, that where different antifraud liability applies to Form S-2 or S-3 than to Form 10-K and the other Exchange Act documents, the quality of disclosure may differ for identical information line items. See note 213 (citing evidence that incorporation by reference may reduce the quality of Securities Act filings).

${ }^{25 s}$ See Michael W. Prozan and Michael T. Fatale, Revisiting "Truth in Securities": The Use of the Efficient Capital Market Hypothesis, 20 Hofstra L Rev 687, 697-703 (1992) (describing the efficient market hypothesis's influence on the SEC's formulation of Forms S-1, S-2 and S-3). Prozan and Fatale note that increased technological advances in the communication of information will lead more companies' securities to trade in an efficient market, thereby putting pressure on the three-tier Form S-1, S-2, and S-3 qualifications to expand incorporation by reference in the future. Id at 702-03.

${ }^{206}$ Of course, under the current system, issuers must follow the gun-jumping rules and prospectus delivery requirements, even with incorporation by reference. Nevertheless, the more information incorporated by reference, the less time the issuer must spend in the gun-jumping phase of the registration process. In the limit, registration with complete incorporation by reference may take place almost instantaneously after the issuer decides to issue securities.

${ }^{252}$ See Shelf Registration, SEC Securities Act Release No 6499, [1983-84 Transfer
} 
tion. ${ }^{258}$ Where incorporation by reference reduces the cost and delay of the registration process, shelf registration allows issuers to incur these costs once and then issue a variable amount of securities reasonably expected to be sold within two years following the initial registration. ${ }^{259}$ S-3 issuers that take advantage of Rule 415 when issuing equity also must either make a fixed price offering or comply with the rule's volume limitations. ${ }^{260}$ Nevertheless, during the two-year time period, S-3 issuers do not have to contend with Section 5's gun-jumping rules because the securities under shelf registration are already registered. ${ }^{261}$

The availability of shelf registration almost completely moved the Securities Act regime toward the company registration model in substance. ${ }^{262}$ Companies using shelf registration to-

Binder] Fed Sec L Rptr (CCH) I 83,449 (Nov 17, 1983); Delayed or Continuous Offering and Sale of Securities, SEC Securities Act Release No 6423, [1982 Transfer Binder] Fed Sec L Rptr (CCH) I 83,250 (Sept 2, 1982).

${ }^{258}$ See Rule 415(a)(1)(x), Securities Act, 17 CFR \& 230.415(a)(1)(x) (1996) (making Rule 415 available for securities registered on Form S-3). Rule 415 also applies to securities sold on behalf of those other than the registrant, securities sold pursuant to an employee benefit plan of the registrant, securities to be issued upon the exercise of outstanding warrants or options, and securities to be issued in connection with a business combination, among other transactions. See Rule 415(a)(1)(i)-(ix), Securities Act, 17 CFR \$ 230.415(a)(1)(i)-(ix) (1996). See also Bloomenthal and Holme, Roberts \& Owen, Securities Law Handt $=n k$ \$ 5.12 (cited in note 27) (describing the requirements of Rule 415 shelf offerings). Since 1992, issuers under Rule 415 have been able to make a "universal" shelf registration, registering an aggregate dollar amount of securities without delineating the exact amount of any particular class of securities for registration. See Simplification of Registration Procedures for Primary Securities Offerings, SEC Securities Act Release No 6943, [1992 Transfer Binder] Fed Sec L Rptr (CCH) II 85,015 (July 16, 1992).

${ }^{25}$ Rule 415(a)(2) provides that securities eligible for shelf registration under Rule 415(a)(1)(x), among others, "may only be registered in an amount which, at the time the registration statement becomes effective, is reasonably expected to be offered and sold within two years from the initial effective date of the registration." Rule 415(a)(2), Securities Act, 17 CFR § 230.415(a)(2) (1996).

${ }^{20}$ See Rule 415(a)(4)(ii), Securities Act, 17 CFR § 230.415(a)(4)(ii) (1996) ("[W]here voting stock is registered, the amount of securities registered for such purposes must not exceed 10 percent of the aggregate market value of the registrants outstanding voting stock held by non-affiliates of the registrant ...."). For S-3 issuers offering equity securities not at a fixed price, the securities must be sold through underwriters and the underwriters must be named in the prospectus that is part of the registration statement. See Rule 415(a)(4)(iii)-(iv), Securities Act, 17 CFR § 230.415(a)(4)(iii)-(iv) (1996).

${ }^{201}$ See SEC Securities Act Release No 6499 (1983) (cited in note 257) ('The Rule enables a registrant to time its offering to avail itself of the most advantageous market conditions.").

${ }^{202}$ From January 1994 to December 1995, S-3 issuers registered $\$ 284.1$ million of common stock through a shelf offering while only registering $\$ 111.1$ million of common through a non-shelf offering. See Advisory Committee Report at 48 (Appendix A) (cited in note 13). See also Margaret A. Bancroft, Responding to Gustafson: Company Registration and a New Negligence Standard, Insights 14, 15 (July 1995) ("Company registration carries the integrated disclosure concept to both its intellectual and practical conclusion.”).

At the time of the implementation of shelf registration, several scholars commented on its desirability. See Barbara A. Banoff, Regulatory Subsidies, Efficient Markets, and 
gether with incorporation by reference in an S-3 registration statement may avail themselves of a two-year period in which they may issue securities into the market without any delay and with only a minimal amount of additional information disclosures. The reduced cost of conducting a public offering under Rule 415 also lowers the incentive of issuers to conduct an exempt transaction. In the extreme, where issuers are able to conduct all offerings through shelf registration without any extra cost or delay, issuers will choose to register almost all their securities and thereby bypass the complex resale provisions of the Securities Act.

The Advisory Committee, nevertheless, argues that the current shelf registration process is inadequate for a couple of reasons. Initially, it contends that issuers may avoid the current shelf registration process due to the fear of "market overhang," whereby the stock price of the issuer drops due to the announcement of a plan to issue additional common stock. ${ }^{263}$ The announcement of a specific amount of securities to be sold over a two year period, the Advisory Committee argues, may engender such a market overhang effect. ${ }^{264}$ Two responses, however, are possible to the Advisory Committee's arguments. First, to the extent a market overhang effect truly is present, the company registration proposal will exacerbate such an effect by essentially placing an infinite amount of securities on the shelf. Second, if a market overhang effect exists, it most likely is due to the signal sent by issuers about the motivation behind their offering of securities-for example, because the market price is overvaluedrather than due to anything inherent in increasing the market capitalization of the company. To the extent such a signal exists and impacts the stock price, it is unclear why the magnitude of the signal is different under either the shelf or company registration approaches. Within both systems, the issuer must at some point before the actual sale of securities indicate to the market its desire to conduct such an offering, generating a clear signal to the market. Although the issuer must signal at an earlier time

Shelf Registration: An Analysis of Rule 415, 70 Va L Rev 135 (1984); Merritt B. Fox, Shelf Registration, Integrated Disclosure, and Underwriter Due Diligence: An Economic Analysis, 70 Va L Rev 1005 (1984).

${ }^{2 \times}$ See Advisory Committee Report at 51-54 (Appendix A) (cited in note 13). Citing data from Advisory Committee member Dr. George Hatsopoulos, the Committee noted that the market overhang effect is greatest for smaller issuers and lower for larger companies, including in particular the pilot companies. See id.

${ }^{24}$ See id at 53-54 (Appendix A) ("[T]he continuing need to specify an aggregate dollar amount of securities to be offered apparently has perpetuated market overhang concerns."). 
under the shelf registration process, this signal is necessarily diluted by the probability that the securities may never be sold off the shelf, whereas the signal of an offering in a company registration setting will result in a larger price drop because the probability of securities being sold is much higher. ${ }^{265}$ Moreover, at the actual offering, regardless of the timing of the signals, to the extent the signals for both shelf and company registration offerings indicate that the managers feel the securities are overpriced, the signals will result in the same price drop in the securities. ${ }^{266}$

The Advisory Committee also points out that Rule 415 only allows issuers to register the amount of securities they reasonably expect to offer in a two-year period. This may result in two disadvantages to issuers. First, issuers unable to plan for the amount of securities they wish to sell may underestimate this amount and thereby lack the same amount of flexibility as issuers under the company registration system. However, although issuers are limited to registering only the amount of securities they "reasonably expect" to sell in two years, in practice courts and the SEC may have difficulty second-guessing the business plans of issuers. Furthermore, to the extent an issuer does face a sudden and dramatically greater need to raise securities not covered under a shelf registration, the issuer can simply register these securities separately using Form S-3, incorporating by reference much of the required information. ${ }^{267}$ The second disadvantage to issuers is that they must re-register the securities every two years to maintain their shelf offering. Again, however, the

\footnotetext{
${ }^{25}$ Of course, once the issuer decides to takedown securities from the shelf, an additional signal will be sent to the market. The combination of this takedown signal with the earlier signal from the initiation of the shelf offering should equal the magnitude of the one signal generated by the company registration notice of an offering.

${ }^{206}$ The Advisory Committee also argues that short-sellers may become more active when the potential supply of securities is increased because their risk of a squeeze is reduced. See Advisory Committee Report at 53 (Appendix A) (cited in note 13). However, for companies followed by many analysts and institutional investors, the ability of shortsellers to move the price of securities away from their fundamental value is suspect. Moreover, the potential increased supply of securities is even greater under the company registration system that essentially places an infinite amount of securities on the shelf.

${ }^{27}$ Most takedowns from the shelf occur within sixty days of the initial filing of the Form S-3 registration statement. See id at 54 (Appendix A). This provides evidence that issuers do not value the ability to avoid filing a subsequent Form S-3 registration statement. Furthermore, although some argue that issuers value the flexibility company registration grants in being able to time the market and issuer securities quickly when market conditions dictate, the actual small usage of shelf takedowns past sixty days from the initial Form S-3 filings runs counter to this argument. If issuers truly did value the flexibility of offering securities in coordination with market conditions, one would expect to see more shelf takedowns later in the life of a shelf registration.
} 
magnitude of this additional burden is unclear given the ability of issuers to incorporate-by-reference under Form S-3. Moreover, simply reducing SEC review of Form S-3 companies alone will reduce the delay on shelf-offerings. ${ }^{268}$

Then, in 1990, recognizing the growing role of institutional investors in the capital markets and in order to combat the growing trend of such investors foregoing the United States in favor of other countries with more lax securities regulation, the SEC instituted Rule 144A to provide for a liquid market solely for QIBs. ${ }^{269}$ To qualify for Rule 144A, institutional investors must meet QIB requirements setting minimum investment thresholds. ${ }^{270}$ Under Rule 144A, restricted securities may be sold freely to QIBs without regard to any resale limitation or information requirement. ${ }^{271}$ The securities sold through Rule 144A, however, may not consist of the same class of any security of the issuer

\footnotetext{
${ }^{258}$ The Committee also points out that Rule 415 places several additional limitations on "at-the-market" offerings of equity securities. Id. See Rule 415(a)(4), Securities Act, 17 CFR § 230.415(a)(4) (1996). Here, the Committee's point is valid in that the current shelf registration system may be inferior to the company registration proposal. Again, however, it is unclear why this particular disadvantage of shelf registration cannot simply be handled through reform to Rule $\mathbf{4 1 5}$ directly. If it is true that the limits on at-the-market equity offerings are an unnecessary burden, why not simply repeal these limits directly? Additionally, the Committee notes that the filing fee for shelf registration is nonrefundable and payable at the time of registration rather than at the takedown of securities from the shelf as would be the case under company registration's "pay-as-you-go" system. However, switching to a pay-as-you-go system could be accomplished fairly easily under the current shelf registration process. Moreover, especially for pilot companies conducting a relatively large offering, it is unclear how the manner or timing of SEC filing fees that constitute only a minuscule fraction of the offering transaction costs affect the public offering process. For Form S-3 shelf registrations from 1993-95, the combined total of registration fees, legal fees, accounting fees, state registration fees, and printing costs amounted to only 0.4 percent of the offering amount. See Advisory Committee Report at 46 (Appendix A) (cited in note 13).

${ }^{205}$ Rule 144A, Securities Act, 17 CFR § 230.144A (1996). See also Bloomenthal and Holme, Roberts \& Owen, Securities Law Handbook \$ 11.01 (cited in note 27) (describing Rule 144A and the PORTAL market). The scope of Rule 144A resales has grown dramatically. From eight placements totaling $\$ 916$ million in 1990, the use of Rule $144 \mathrm{~A}$ grew to 243 placements totaling $\$ 44.672$ billion in 1993. Staff Report on Rule 144A, [1994-95 Decisions] Fed Sec L Rptr (CCH) II 85,428 (Aug 18, 1994).

${ }^{270} \mathrm{~A}$ Qualified Institutional Buyer is defined in Rule $144 \mathrm{~A}(\mathrm{a})(1)$ as an institutional entity that in the aggregate owns and invests on a discretionary basis at least $\$ 100$ million in securities of issuers that are not affiliated with the entity .... Rule 144A(a)(1)(i), Securities Act, 17 CFR § 230.144A(a)(1)(i) (1996). Dealers registered pursuant to Section 15 of the Exchange Act must meet only a $\$ 10$ million requirement. Rule 144A(a)(1)(ii), Securities Act, 17 CFR § 230.144A(a)(1)(ii) (1996).

${ }^{27}$ See Rule 144A(b), Securities Act, 17 CFR § 230.144A(b) (1996). Sellers must ensure that the purchaser in fact is a QIB (or is reasonably believed to be a QIB). Rule 144A(d)(1), Securities Act, 17 CFR \& 230.144A(d)(1) (1996). Furthermore, the seller must take reasonable steps to ensure that the purchaser is aware that the seller is relying on an exemption from Section 5's registration requirements. Rule 144A(d)(2), Securities Act, 17 CFR § 230.144A(d)(2) (1996).
} 
listed on a U.S. securities exchange or traded on an automated U.S. interdealer quotation system, such as NASDAQ. ${ }^{272}$ Furthermore, for the securities of non-Exchange Act reporting issuers, the purchaser has the right to demand certain specified information at its discretion. ${ }^{273}$

Rule 144A provides a means for at least some investors-the QIBs - to trade restricted securities. Furthermore, issuers may use Regulation D to sell securities to QIBs directly, and thereby initiate Rule $144 \mathrm{~A}$ trading. ${ }^{274}$ The combination of Regulation D and Rule 144A results in a special trading market for restricted securities without any mandatory information disclosure on the issuer's part and no holding period requirement. ${ }^{275}$ Because special information requirements exist for non-Exchange Act reporting companies, however, QIB markets are more likely to arise for companies that make Exchange Act filings. Recall that one of the major differences between the company registration model and the current system is that the trading status of a company's securities under company registration depends not on the particular path by which each individual security entered the market but rather on the capitalization and quality of the underlying company. The QIB market established under Rule 144A, therefore, blurs the distinction between the transaction-based

${ }^{272}$ See Rule 144A(d)(3), Securities Act, 17 CFR § 230.144A(d)(3) (1996). Whether a security meets this fungibility criterion is determined as of the date when the Rule 144A securitíes were initially issued. Id.

${ }^{273}$ Rule 144A(d)(4), Securities Act, 17 CFR § 230.144A(d)(4) (1996).

${ }^{274}$ See Rule 144A, Prelim Note 7, 17 CFR § 230.144A (1996) (providing that purchasers in a Regulation D offering may acquire the securities with a view to reselling the securities under Rule $144 \mathrm{~A}$ without affecting the initial Regulation D exemption). Issuers themselves may not use Rule 144A because Rule 144A simply protects the issuers from being labeled as underwriters under Section 2(11). Because Section 4(1), however, requires that the transaction involve no issuer, underwriter, or dealer, issuers must still satisfy Section 5's registration requirements unless they find another exemption, such as Rule 506 of Regulation D. Rule 506, Regulation D, 17 CFR $\$ 230.506$ (1996).

${ }^{27}$ Through NASDAQ's "PORTAL Market," QIBs may now easily trade in restricted securities, significantly reducing the liquidity penalty of such securities. See SelfRegulatory Organizations; Order Approving Proposed Rule Change by the National Association of Securities Dealers, Inc., Relating to a Security Application Fee for The PORTAL Market, Exchange Act Release No 34,562, 59 Fed Reg 44,210 (Aug 19, 1994).

The rationale behind resale restrictions and the resale exemptions in Rule 144 and Rule 144A turns on the transaction focus of the Securities Act. The resale limitation is necessary to prevent issuers from avoiding the volume, number of investors, and manner of sale limitations imposed under the various transaction exemptions to Section 5 . If the investor's resale is in reality part of the issuer's initial transaction-where, for example, the investor acts as a Section 2(11) underwriter for the issuer-then resales to those outside the scope of the initial transaction exemption must be restricted to maintain the exemption's limitations. Suppose Acme, Inc. sells bonds through an intrastate offering under Section 3(a)(11). If investors were able to resell the securities immediately to out-ofstate investors, issuers would easily be able to undo the intrastate limitations. 
Securities Act regime and company registration, creating a liquid market for even restricted securities of Exchange Act reporting companies.

Finally, the SEC'S EDGAR system of electronic filing combined with the growth of easy access avenues to EDGAR through the Internet has reduced the difference between the means of information dissemination used in the Securities Act and Exchange Act. Where even as recently as a few years ago, investors had to locate Exchange Act filings physically at the SEC or rely on a commercial intermediary to locate those filings, investors may now simply turn to several different Internet web sites to access filings for a particular company. ${ }^{276}$ As well, investors may use these same Internet sites to access filings and prospectuses for companies undergoing a public offering transaction pursuant to the Securities Act. For both the Securities Act and Exchange Act information disclosure provisions, the introduction of new inexpensive and quick means of information dissemination reduces the importance of the formal differences in the approaches the two Acts take to distributing information.

In summary, the Securities Act and Exchange Act are not as far apart in practice as their different transaction- and statusbased frameworks would suggest. The introduction of integrated disclosure, incorporation by reference, shelf registration, Rule 144A trading, and the EDGAR filing system substantially brought elements of company registration into the Securities Act. Information disclosure under Form S-3 and shelf registration now occur largely through periodic disclosure and incorporation by reference, as in a status-based regime. Although information during an offering is still distributed primarily to the transacting parties, ${ }^{277}$ the bulk of the actual disclosure occurs through the periodic SEC filings if this information is incorporated by reference from Exchange Act documents. Investors, moreover, may find most Securities Act and Exchange Act information on the Internet through the EDGAR system. The availability of shelf registration further reduces the burden on issuers of meeting the transaction-specific requirements of an offering and thereby reduces the importance of the exemptions to Section 5. Finally, although some restricted securities are still issued in the current system, the QIB market has reduced the importance of the liquidity penalty which many shares of restricted securities expe-

\footnotetext{
${ }^{276}$ For instance, investors may look to the SEC's own site at www.sec.gov or to a commercial provider such as at www.disclosure.com.

${ }^{m}$ See Coffee, 52 Wash \& Lee L Rev at 1159 (cited in note 11) (listing the prospectus delivery requirement as one obstacle to administrative integration of the securities laws).
} 
rience. It therefore remains an empirical question whether the remaining differences-involving the prospectus delivery requirements, limits on shelf registration, and treatment of restricted securities-amount to much practical difference.

Moreover, the Advisory Committee Report calls for company registration only where it is most warranted: for the pilot companies. Given the ability of pilot companies to engage in shelf registrations within the current regime, however, the marginal benefits of extending the shelf registration time period are unclear. Indeed, Coffee and two fellow Advisory Committee members-Edward F. Greene and Lawrence W. Sonsini-expressed doubt that companies will view the benefit of continuous shelf registration as enough to induce them to voluntarily elect into the company registration pilot program. ${ }^{278}$ Outside the pilot companies, real questions remain as to the scope of company registration. In some cases, where companies do not trade in an efficient market, retaining some aspects of the transaction-based system may further investor welfare. A whole-hearted formal transition to a company registration system, therefore, may not be warranted for the entire market. To the extent that only S-3 companies deserve company registration treatment, a less radical reform-such as instituting a broader shelf registration system-may accomplish the same substantive goals as company registration without the accompanying administrative change for non-S-3 companies. Furthermore, reform should leave open the possibility of private placements for S-3 companies at their own discretion. As the next Part discusses, providing a private placement option improves social welfare, even in a company registration system. Finally, although the Advisory Committee did concern itself with some aspects of the Securities Act's liability provisions, ${ }^{279}$ it missed the area where reform would provide the most benefit: status-based antifraud liability. As this Article discusses below, shifting toward a more status-based antifraud regime will move the current Securities Act framework even closer to the substantive ideal of company registration. Moreover, and perhaps more importantly, status-based antifraud liability also

${ }^{278}$ See Advisory Committee Report at 40-41 (cited in note 13) (separate statement of John C. Coffee Jr., Edward F. Greene, and Lawrence W. Sonsini) (commenting on "how weak the incentives may be to elect into a voluntary company-registration system, especially in light of the growing use of unallocated shelf registration statements").

${ }^{279}$ The Advisory Committee did consider a number of different antifraud schemes to go along with company registration. Id at 110-11. Although these proposals advocated varying antifraud liability by type of transaction or investor involved, none of them advocated introducing a status-based determination of how to apply antifraud liability. 
provides more effective deterrence against fraud while conserving scarce enforcement resources.

\section{COMPANY REGISTRATION AND ANTIFRAUD LIABILITYY}

Given the array of reforms in the 1980s that introduced most of the substantive aspects of company registration into the securities laws, the greatest source of remaining complexity and tension between the transaction- and status-based approaches lies in the availability of exempt nonpublic offerings. For example, the use of private placements requires that securities of the same issuer be tracked separately and treated differently depending on the path they take to market. This is true even for securities of the same class. One easy way to eliminate this last vestige of transaction-based regulation would be to do away with private placements and other transaction exemptions to Section 5's registration requirements. The Advisory Committee failed to recommend such a radical reform, and for good reason. Private placements serve a valuable social function, allowing issuers to raise capital for information-sensitive projects that otherwise would go unfunded, benefiting the issuers, investors, and society. Recognizing this, the Advisory Committee put forth a new "limited" exemption under the full company registration pilot and would allow all current transaction exemptions to continue under the modified pilot program. ${ }^{280}$ This Part discusses (a) the benefit of retaining some sort of transaction exemption and (b) how shifting to status-based antifraud liability retains these benefits while reducing the substantive magnitude of the complexity and tension in the current system's dual transaction- and statusbased approaches.

\section{A. Preserving the Private Placement}

In choosing between conducting a private placement or a public offering, companies weigh several factors, including the required information disclosure and the level of antifraud liability. ${ }^{281}$ Private placements force issuers and investors to endure

\footnotetext{
${ }^{250}$ Coffee argues that shortening the holding period for restricted securities in Rule. 144 and expanding the scope of the QIB market to include listed securities would greatly increase the ability of issuers to raise capital quickly and inexpensively. See Coffee, 52 Wash \& Lee L Rev at 1179 (cited in note 11) ("II]t is not self-evident that companyregistration will produce greater gains than those that might result from liberalizing the private placement exemption.").

${ }_{231}$ In the United States, private placements went from $\$ 16$ billion in 1980 to $\$ 170.7$ billion in 1989. This represented a jump from 22 percent of all corporate financing to 35.5 percent. See Kenneth F. Oettle, Publicly Traded Securities Are A Waiver Prerequisite, 135
} 
one substantial cost: the shares sold through a private placement are typically restricted and therefore lack liquidity. ${ }^{282}$ In contrast, private placements allow companies to reduce the level of their antifraud liability exposure and cost of disclosure.

The Advisory Committee's proposed full company registration system would eliminate almost all forms of exempt transactions under Section 5, including private placements. Eliminating private placements would greatly simplify a number of transactions under the Securities Act. Under the current system, securities issued through a private placement are restricted and subject to resale limitations typically for two years after the placement. $^{283}$ Because Section 5 of the Securities Act governs all transactions, subsequent resellers of the security must find their own exemption from Section 5. Resellers typically use Rule 144's exemption; some larger institutions may engage in resales sooner than two years after the placement through Rule 144A. ${ }^{284}$ The full company registration system eliminates the need for these complex resale limitations. No longer would investors, issuers, and their attorneys need to trace the history of each individual security they sold; rather, they would only need to focus on the type of security and information general to the entire issuer's valuation.

The benefits derived from eliminating private placements, however, are overstated. First, many companies may already approximate many of the benefits afforded by a private placement through a public offering, thereby reducing the number of issuers voluntarily selecting to conduct a private placement and the volume of restricted securities. Through shelf registrations, for example, large companies may already approximate the speed of private placements through a normal public offering. Further-

NJ L J 919, 941 (1993) (citing figures published by IDD Information Services). See also Mark Carey, et al, The Economics of Private Placements: A New Look, 2 Fin Markets, Institutions \& Instruments 1, 23 (Aug 1993) (noting that life insurance companies owned 82.6 percent of the private placement market from 1990-92 and that pension funds, finance companies, mutual funds, insurance companies, commercial banks, and investment banks owned the remainder).

Stanley Keller has noted that many companies today conduct a private placementpublic offering hybrid consisting of a traditional private placement followed immediately with shelf registration to allow purchasers to resell their securities. See Stanley Keller, Basic Securities Act Concepts Revisited, Insights 5, 7 (May 1995) (noting that through "private investment, public equity" or "PIPE" transactions, issuers can enjoy many of the benefits of both private placements and public offerings).

${ }^{222}$ See Rule 502(d), Securities Act, 17 CFR \& 230.502(d) (1996) (providing that securities acquired in a transaction under Regulation D, except under Rule 504(b)(1), cannot be resold without registration or an exemption from registration).

${ }^{223}$ See Rule 144, Securities Act, 17 CFR § 230.144 (1996).

${ }^{24}$ See Rule 144A, Securities Act, 17 CFR $\$ 230.144$ A (1996). 
more, under a status-based antifraud regime, the use of one form of offering over another would no longer provide an antifraud liability advantage. Accordingly, many offerings which today are conducted through private placements would, under a statusbased antifraud regime, voluntarily be shifted toward a public offering. Once issued through a public offering, investors, issuers, and their attorneys would no longer need to trace the history of such securities.

Second, private placements may still serve some purpose even under a company registration system. In particular, private placements provide for reduced mandatory information disclosure. Companies issuing securities under a private placement need not assemble a formal registration statement, although many will voluntarily provide similar information to attract investors. Furthermore, because investors are small in number and the information disclosed is not required to be made public or filed with the SEC, companies are often able to provide information on a confidential basis. ${ }^{285}$ This allows companies to attract investors to projects containing sensitive information in a manner that such companies could not conduct in a public offering, benefiting the capital markets and society as a whole.

Indeed, the Advisory Committee recognizes the benefit of allowing even registrants in a full company system to make "limited exemption" offerings to a few accredited investors. ${ }^{286}$ Under the limited exemption, issuers would be able to convey confidential information to purchasers without filing such information with the SEC. Nevertheless, the limited exemption is inferior to retaining the current set of private placement exemptions under a status-based antifraud rule for several reasons. First, the limited exemption still provides a level of antifraud liability that is different from registered transactions. Although the Advisory Committee recommends that the liability provisions of the Securities Act apply to limited exemption securities, ${ }^{287}$ because Section 11 requires a registration statement and Section

\footnotetext{
${ }^{225}$ See Lisa K. Bostwick, Note, The SEC Response to Internationalization and Institutionalization: Rule 144A Merit Regulation of Investors, 27 L \& Pol Intl Bus 423, 426 (1996) ("CP\}rivate placements offer issuers many advantages over public offerings, especially opportunities for cost-effective, expedient, confidential, and flexible financing."); Coffee, 52 Wash \& Lee L Rev at 1174 (cited in note 11) ("[I]n private transactions the purchaser, or its agents, has a greater opportunity to conduct 'hands-on' due diligence and to receive private information (forecasts, estimates, and valuations) that the issuer would feel uncomfortable including in a registration statement.").

${ }^{2 \infty}$ See text accompanying notes 200-05 (describing transaction exemptions to the Advisory Committee's full and modified company registration system).

${ }^{297}$ See Advisory Committee Report at 102 (cited in note 13).
} 
12(a)(2) requires a prospectus - both of which are missing in a limited exemption until the issuer makes full disclosure through a Form 8-K-the limited exemption effectively provides issuers with a reduced exposure to antifraud liability. Issuers, therefore, would have an artificial incentive to avoid registering simply to reduce their antifraud exposure; furthermore, as discussed above, ${ }^{288}$ the difference in antifraud protection does not further disclosure goals, at least for companies trading in an efficient market. Second, the limited exemption does not include unaccredited investors and thereby leaves significant numbers of investors out of the investment opportunities provided by private placements. Although the current private placement exemptions under Regulation D are mostly aimed at sophisticated investors, some unsophisticated investors are able to participate. ${ }^{289}$ Third, because the limited exemption represents a new rule, it would force all parties to incur uncertainty costs in working out the mechanics of the rule.

One final difference between the current private placement system and the Advisory Committee's limited exemption is the holding period requirement. Rather than subject the securities sold in a limited exemption to any bright-line holding period, the Advisory Committee simply restricts purchasers from making sales of the exempted securities (or similarly priced securities) until the issuer makes a public filing on the confidential information (the public filing requirement). Note that both the current private placement's holding period and the public filing requirement serve similar functions, imposing a liquidity penalty on unregistered securities. ${ }^{290}$ Allowing private placements without resale restrictions, for example, would undermine the public offering system from an ex ante perspective. Given the choice between meeting the disclosure requirements of a public offering or conducting a private placement, many companies would simply choose the private placement and thereby avoid mandatory disclosure. ${ }^{291}$ Moreover, where private placements involve confiden-

See text accompanying notes 43-53.

${ }^{239}$ See Rule 505, Securities Act, 17 CFR $\S 230.505$ (1996). Of course, some would argue that cutting non-sophisticated investors out of private placements altogether would result in fewer defrauded investors. Rational, non-sophisticated investors, however, can make the choice themselves whether to partake of a private placement.

${ }^{20}$ See Bostwick, Note, $27 \mathrm{~L}$ \& Pol Intl Bus at 428 (cited in note 285) (noting that issuers in a private placement experience a ten to fifteen basis point illiquidity penalty).

${ }^{{ }^{2}}$ Some commentators, however, argue that companies will voluntarily release information to distinguish themselves from lower-quality companies. See Frank H. Easterbrook and Daniel R. Fischel, Mandatory Disclosure and the Protection of Investors, $70 \mathrm{Va}$ L Rev 669 (1984). But see John C. Coffee, Jr., Market Failure and the Economic Case for A Mandatory Disclosure System, 70 Va L Rev 717, 723 (1984) (arguing for a mandatory 
tial information, allowing free resale after a private placement may result in the loss of investor confidence among nonparticipating investors. In some sense, the confidential information puts the private placement investors in a similar position as insiders. If they are allowed to freely trade their securities, other investors in the market may lose confidence in the fairness of the system. Investors, of course, may respond by discounting the value of all securities. Managers, however, may nevertheless use private placements as an indirect means to profit from insider trading. If managers then adjust corporate information disclosure or the corporate projects they undertake to take advantage of this insider trading ability, then society is harmed. A resale limitation reduces the risk of insider information trading. Indeed, the logic of this argument calls for treating all the trades of a private placement investor-whether in private placement or registered securities-as suspect and therefore restricted. ${ }^{292}$

Nevertheless, the public filing resale requirement of the limited exemption is inferior to the holding period requirement. As a bright-line rule, the holding period requirement provides more certainty for investors. Conversely, investors in the limited exemption must rely on the issuer to make a public filingsometimes years after the initial purchase-in order to resell their securities. ${ }^{293}$ Furthermore, by the very nature of the information disclosed to investors in the limited exemption, outside investors would face large hurdles in proving whether the public filing requirement was actually met. Finally, most confidential projects typically either resolve themselves during the two-year holding period or have already become known to the market in the time period. ${ }^{294}$

disclosure system).

${ }^{252}$ The Advisory Committee's limited exemption would restrict purchasers of securities from trading not only the limited exemption securities but all other price-related securities of the issuer. See Advisory Committee Report at 102 (cited in note 13).

${ }^{23}$ Investors may obtain contractual guarantees from issuers; issuers, however, may resist such guarantees to avoid putting the very information they intended to keep confidential into the terms of the contract.

${ }^{24}$ Coffee similarly argues that a holding period will induce institutional investors to take better care in evaluating and monitoring private placement investments, thereby benefiting the entire capital market. See Coffee, 52 Wash \& Lee L Rev at 1183-84 (cited in note 11) ("[S]o long as some significant period of illiquidity remains, whether two years or one, institutions that buy in private placements have a stronger incentive to monitor and perform due diligence investigations than those that buy otherwise equivalent securities in public markets."). 


\section{B. Substantive Company Registration}

Given the SEC's recent interest in moving toward a formal company registration system, a status-based antifraud regime provides an important benefit: status-based liability achieves most of the substantive benefits of the Advisory Committee's company registration system with less disruption in the existing regulatory structure. The primary benefit of the Advisory Committee's proposal is to extend shelf registration indefinitely. Even here, however, it is unclear that relieving companies of the burden to re-register securities for the shelf every two years provides much benefit. As discussed in Section II.C, Form S-3 companies can now approximate almost all the benefits of a company-based registration system. ${ }^{295}$ Through incorporation by reference and Rule 415 shelf offerings, S-3 companies may avoid most of the strictures of the gun-jumping rules and offer securities on short notice to the public. The main roadblock to achieving company registration is not that companies lack the avenue to quickly and inexpensively register securities under the Securities Act.

Company registration is undermined within the current system by the many transaction exemptions to Section 5 that create numerous, artificial distinctions between different securities of the same issuer. The Advisory Committee's proposal, however, does not completely eliminate this weakness in the current regime. Even under the Advisory Committee's full company registration system, some companies may still choose, given the opportunity, to conduct a limited exemption placement or a nonconvertible debt private placement. Companies and investors making the selection for an exemption lose liquidity, but gain the benefits of reduced antifraud liability and truncated mandatory disclosure. As discussed above, such transaction exemptions may prove socially valuable to the extent more wealth-increasing confidential projects are undertaken by firms. ${ }^{296}$ Nevertheless, the availability of transaction exemptions-no matter how valuable to society-weakens the company registration system and reintroduces the need for complex resale rules.

Some, therefore, may contend that a formal company registration system is essential to relieve issuers of the gun-jumping restrictions and investors of the complex resale limitations placed on restricted securities. However, a regime of status-based antifraud rules for primary transactions coupled with a longer

\footnotetext{
${ }^{2 \times}$ See Section II.C (describing the substantive shift in the Securities Act toward a company registration system that has already occurred).

${ }^{26}$ See text accompanying notes $281-94$.
} 
shelf registration period would also relieve issuers and investors of these burdens and at a lower uncertainty and transitional cost. First, shelf registration already relieves issuers of the need to comply with the gun-jumping rules except at periodic two-year intervals when the issuers must re-register for the shelf. Extending the shelf registration period past the two-year mark will further diminish the cost of the gun-jumping rules on shelfregistration-eligible issuers.

Second, the magnitude of the complexity problems caused by the resale limitations varies directly in proportion to the volume of securities going through an exempt transaction. With statusbased antifraud liability rules combined with shelf registration, however, the incentives to conduct an exempt offering are greatly reduced. Only those issuers desiring to maintain some amount of confidentiality in their information disclosures to particular investors will continue to use the exempt offering mechanism. No longer will issuers choose a private placement because of its reduced antifraud liability; furthermore, shelf registration removes the advantage of speed and low-transaction costs enjoyed by exempt offerings. With both status-based antifraud liability and shelf registration, in fact, investors will push issuers for registration to gain the benefit of liquidity. As the importance of exempt transactions diminishes, the securities of most companies will consist almost entirely of registered and liquid capital. Through Exchange Act filings, all security holders will obtain updated information specific to the company. In substance, moving to a status-based antifraud regime will result in the vast majority of S-3 and S-2 companies mimicking company-registered capital structures. For those few companies that choose nevertheless to engage in a private placement and suffer the cost of illiquidity, society will still benefit as both issuer and investor gain the benefit of keeping sensitive company information in confidence. ${ }^{297}$

\section{CONCLUSION}

Company registration is a concept whose time has come and gone and now has come again. The first major efforts toward company registration reform, culminating in the ALI model federal securities code, met with failure in the early 1980s. Ultimately, many of company registration's substantive aspects

\footnotetext{
${ }^{20}$ Note that this argument does call for reducing the number of different transaction exemptions in the current system to those absolutely necessary to allow companies to engage in confidential wealth-increasing projects. Therefore, although Regulation $\mathrm{D}$ private placements should be retained, the SEC and Congress may wish to consider eliminating intrastate offering and Regulation A exemptions, among other exemptions.
} 
found expression in the current regime's integrated disclosure, incorporation by reference, and shelf registration provisions. Today we face another movement to install a formal company registration system. As framed by the Advisory Committee, company registration would incorporate not only formal company-centered disclosure, but a whole host of peripheral reforms. At its core, the Advisory Committee proposal's contribution is a continuous shelf registration process. New Form C-1 registrants would gain the ability to issue securities with only a minimal amount of transaction and company-specific disclosure. Depending on the size and type of the particular offering, companies could either file this information on a Form 8-K, as part of the registration statement, or as a supplement to the prospectus. In either case, issuers using Form C-1 would avoid the cost, delay, and gun-jumping rules associated with the current public registration process, much as companies enjoying shelf registration do today on a more limited scale.

Although containing many positive aspects, the Advisory Committee proposal nevertheless leaves many issues and questions unanswered. For example, if company registration is justified for companies whose securities trade in an efficient market, what of smaller companies trading in less efficient markets? The transaction-specific aspects of the proposal that differentiate between different size offerings also add needless complexity to company registration. Finally, it is unclear whether the peripheral reform proposals offered by the Committee-concerning top management certification, due diligence duties, and enhanced disclosure-are either warranted or necessary to a company registration system.

In response to the shortcomings of the Advisory Committee's proposal, this Article suggests an alternative approach centered around status-based antifraud liability. The Article recommends varying the elements of antifraud liability, including materiality (as embodied in the forward-looking safe harbor), scienter, and third-party liability with the status of the company. Employing these elements, this Article suggests the following antifraud system: S-3 companies should enjoy Level III liability, providing for a limited form of scienter-based liability regardless of the type of primary transaction or document in question. Third-party associates would not face any legal liability and forward-looking statements would enjoy broad safe harbor protection under Level III liability. S-2 companies and their third-party associates would face Level II liability, consisting of negligence-based liability with an intermediate forward-looking statement safe harbor. Finally, 
S-1 companies would bear the highest form of antifraud liability, Level I liability. Under Level I liability, issuers and their identified third-party associates would face strict liability and enjoy only a restricted scope safe harbor for forward-looking statements. ${ }^{298}$ In the case of private placements where investors may possess more sophistication, moreover, one possible transactionbased addition to the status-approach advocated in this Article is perhaps warranted: The level of liability on Form S-1 companies should be mitigated to Level II liability to take into account the ability of sophisticated investors to account better for the risk of fraud.

This status-based liability scheme provides two benefits over the current system and the Advisory Committee's proposals. First, antifraud liability would be applied where it is most needed. Form S-3 companies face a greater array of alternative market-based antifraud devices than do S-1 companies. Managers of S-3 companies realize that more public information surrounds their company, restricting their ability to misstate the value of the company. Greater numbers of third parties acting as gatekeepers or certifiers can also assess the value of larger, more well known companies able to spread the fixed cost of such services across a greater number of shareholders. Where these market-based mechanisms reduce the amount of fraud-and therefore the gain-from employing more antifraud legal liability, reducing antifraud liability becomes more justified for S-3 companies. Furthermore, S-3 companies-which tend to be larger, have deeper pockets, and engage in larger issues of securities-are at greater risk from frivolous litigation that may accompany higher levels of antifraud liability.

Second, a status-based antifraud regime would, in effect, lead the current system to the same substantive result as a company registration regime. The institution of the current shelf registration system in 1983 dramatically reduced the costs to S-3 companies of going public. In fact, the primary advantage of private placements and other exempt transactions lies in their reduced antifraud liability. With a status-based antifraud regime, however, this distortive advantage is removed. Without this advantage, most eligible companies will voluntarily select a shelf offering, extending the coverage of Securities Act registration to the vast majority of companies and securities. Conversely, companies would still be allowed to conduct a private placement to

${ }^{28}$ For an outline of Level I-III liability, see Part I.C. 
obtain financing for confidential projects, unlike the full company registration system.

This Article has set forth the basics of a status-based antifraud regime. Although placing more liability on smaller, lesser known companies may seem "unfair," it is no more unfair than denying the lesser known companies the ability to conduct shelfofferings or the ability to incorporate by reference. Moreover, today's current system, which places the same liability on all companies regardless of size, market capitalization, or access to market-based antifraud mechanisms, could be considered unfair and distortive from a societal perspective. Although other alternatives to the antifraud regime proposed in this Article are possible, status-based antifraud remains the best means to continue the legacy of Milton Cohen. 
•

- 